UNIVERSIDADE DE BRASÍLIA - UnB

INSTITUTO DE LETRAS - IL

DEPARTAMENTO DE LÍNGUAS ESTRANGEIRAS E TRADUÇÃO - LET PROGRAMA DE PÓS-GRADUAÇÃO EM ESTUDOS DA TRADUÇÃ̃O POSTRAD

\title{
TRADUÇÃO, REPRESENTAÇÕES SOCIAIS E IDEOLOGIA: O TRADUTOR ENTRE CULTURAS DISTINTAS
}

\author{
VERA LÚCIA CAMELO NERI
}

DISSERTAÇÃO DE MESTRADO EM ESTUDOS DA TRADUÇÃO 
INSTITUTO DE LETRAS - IL

DEPARTAMENTO DE LÍNGUAS ESTRANGEIRAS E TRADUÇÃO - LET PROGRAMA DE PÓS-GRADUAÇÃO EM ESTUDOS DA TRADUÇÃO POSTRAD

TRADUÇÃO, REPRESENTAÇÕES SOCIAIS E IDEOLOGIA: O TRADUTOR ENTRE CULTURAS DISTINTAS

VERA LÚCIA CAMELO NERI

ORIENTADOR: PROF. DR. HANS THEO HARDEN

DISSERTAÇÃO DE MESTRADO EM ESTUDOS DA TRADUÇÃo 


\section{REFERÊNCIA BIBLIOGRÁFICA E CATALOGAÇÃO}

NERI, Vera Lúcia Camelo. Tradução, representações sociais e ideologia: o tradutor entre culturas distintas. Brasília: Departamento de Línguas Estrangeiras e Tradução, Universidade de Brasília, 2017, 100 f. Dissertação de mestrado.

Documento formal, autorizando reprodução desta dissertação de mestrado para empréstimo ou comercialização, exclusivamente para fins acadêmicos, foi passado pela autora à Universidade de Brasília e acha-se arquivado na Secretaria do Programa. A autora reserva para si os outros direitos autorais, de publicação. Nenhuma parte desta dissertação de mestrado pode ser reproduzida sem a autorização por escrito da autora. Citações são estimuladas, desde que citada a fonte.

\section{FICHA CATALOGRÁFICA}

Neri, Vera Lúcia Camelo.

Tradução, representações sociais e ideologia: o tradutor entre culturas distintas / Vera Lúcia Camelo Neri - Brasília, 2017.

$97 \mathrm{f}$.

Dissertação de mestrado - Programa de Pós-Graduação em Estudos da Tradução (POSTRAD) do Departamento de Línguas Estrangeiras e Tradução (LET) da Universidade de Brasília (UnB).

Orientador: Hans Theo Harden.

1. Uma luz para a memória. 2. Teoria das representações sociais aporte teórico. 3. Tradução em contexto ideológico. 4. Considerações finais. II. Título. 
UNIVERSIDADE DE BRASÍLIA - UnB

INSTITUTO DE LETRAS - IL

DEPARTAMENTO DE LÍNGUAS ESTRANGEIRAS E TRADUÇÃO - LET PROGRAMA DE PÓS-GRADUAÇÃO EM ESTUDOS DA TRADUÇÃO POSTRAD

TRADUÇÃO, REPRESENTAÇÕES SOCIAIS E IDEOLOGIA: O TRADUTOR ENTRE CULTURAS DISTINTAS

VERA LÚCIA CAMELO NERI

DISSERTAÇÃO DE MESTRADO SUBMETIDA AO PROGRAMA DE PÓS-GRADUAÇÃO EM ESTUDOS DA TRADUÇÃO, COMO PARTE DOS REQUISITOS NECESSÁRIOS À OBTENÇÃO DO TÍTULO DE MESTRE EM ESTUDOS DA TRADUÇÃO.

APROVADA POR:

PROF. DR. HANS THEO HARDEN - UnB

(ORIENTADOR)

PROF. DR. RENÉ GOTTLIEB STREHLER - UnB (EXAMINADOR INTERNO)

PROFA. DRA. ORLENE LÚCIA DE SABOIA CARVALHO - UnB (EXAMINADORA EXTERNA)

PROFA. DRA. ALESSANDRA RAMOS DE OLIVEIRA HARDEN UnB (SUPLENTE) 
Dedico ao meu pai, Luiz Gonzaga Camelo, velho capitão do mar, que, por noventa anos, navegou pela vida com muita alegria e humor. 


\section{AGRADECIMENTOS}

Ao meu Deus misericordioso, pelo seu infinito amor e fidelidade, ao me conceder persistência e capacidade para a realização deste trabalho.

À minha família, especialmente, aos meus netos que, pacientemente, aceitaram e entenderam as minhas muitas ausências em função dos estudos.

Ao estimado Prof. Dr. Hans Theo Harden, que, brilhante e pacientemente, orientou-me durante essa caminhada. Suas palavras de incentivo e apoio, nas horas mais difíceis, e a confiança depositada em mim foram fundamentais para continuar firme em meu propósito.

Ao Prof. Dr. Júlio César Neves Monteiro, por acreditar em mim, concedendo-me acolhimento e atenção em momentos difíceis. Seus conselhos foram acalentadores.

À Profa. Dra. Alessandra Ramos de Oliveira Harden, por sua atenção e dedicação aos seus alunos. Uma profissional que faz a diferença.

À Profa. Dra. Sabine Gorovitz, pelos ensinamentos acadêmicos e por me apresentar a Teoria das Representações Sociais, essencial para a escolha do tema desta Dissertação de Mestrado.

À Profa. Dra. Alice Maria Araújo Ferreira, que, brilhantemente, deu início a minha caminhada pelos Estudos da Tradução.

À Profa. Dra. Luíza Hiroko Yamada Kuwae, minha colega de trabalho e amiga, que não hesitou em me oferecer ajuda para fazer a revisão deste trabalho, mesmo diante de tanto compromisso profissional.

Aos professores que, gentil e generosamente, aceitaram participar dessa Banca Examinadora. Aos funcionários da secretaria do POSTRAD pela atenção aos alunos.

Aos meus colegas de curso, que contribuíram com o compartilhamento de seus conhecimentos, em sala de aula e seminários.

Aos meus colegas de trabalho, que sempre incentivaram e acreditaram em minha capacidade de chegar ao final desse desafio.

À minha colega e amiga Rafaela Lisboa pelo cuidado, pelo carinho incondicional e pela ajuda constante diante de minha dificuldade com os recursos tecnológicos.

À amiga Adriane Zambonato e aos amigos Diogo Saúde e Samuel Dourado pela parceria, amizade e colaboração.

E, finalmente, à querida Raíssa Neumann Simão, a minha eterna gratidão pelo incentivo a participar do processo seletivo para o Mestrado em Estudos da Tradução e pelo apoio nessa caminhada desafiante. 
"O olho do espírito em parte nenhuma pode encontrar mais deslumbramentos, nem mais trevas, do que no homem, nem fixar-se em coisa nenhuma, que seja mais temível, complicada, misteriosa e infinita. Há um espetáculo mais solene do que o mar, é o céu; e há outro mais solene do que o céu, é o interior da alma. [...]"

O Interior da Alma

Victor Hugo, in

'Os Miseráveis' 


\section{RESUMO}

O objetivo desta dissertação é discutir a tradução como produto e com o poder de não só levar o leitor a interagir com outras culturas, mas, sob a perspectiva de transformar opiniões, quando é usada de forma estratégica em contextos ideológicos, com a finalidade de promover a circulação de novos pensamentos e de geração de novas representações. Neste estudo, a Teoria das Representações Sociais, de Serge Moscovici, é apresentada como aporte teórico para o entendimento das representações que se apresentam nas culturas envolvidas, assim como da formação de novas representações geradas por esse trânsito entre culturas. O contexto ideológico da história do Brasil conhecido como Era Vargas (1930-1945) será destacado como referência para o estudo, assim como o autor Stefan Zweig e as versões em português e em inglês de seu original, Brasilien ein land der zukunft, intituladas, respectivamente, Brasil, país do futuro, traduzido por Odilon Gallotti e Brazil land of the future, traduzido por Andrew St. James. Em decorrência desse estudo, serão considerados alguns pontos que contribuíram para que a tradução da obra de Stefan Zweig superasse o seu original.

PALAVRAS-CHAVE: tradução; representações sociais; cultura; ideologia. 


\begin{abstract}
This dissertation aims to discuss translation as a product with the power not only to lead the reader to interact with other cultures but, from the perspective of transforming opinions when used strategically in ideological contexts, to promote the circulation of new thoughts and generate new representations. The Theory of Social Representations by Serge Moscovici is presented in this study as a theoretical contribution to the understanding of the representations which are presented in the cultures involved in the translation process, as well as the formation of new representations. The ideological context of the history of Brazil, known as Era Vargas (1930-1945), will be highlighted as a reference for the study, as well as the author Stefan Zweig and the Portuguese and the English versions of his original, Brasilien ein land der zukunft, entitled respectively Brasil, país do futuro, translated by Odilon Gallotti, and Brazil land of the future, translated by Andrew St. James. As a result of this study, some points that contributed to the translation of Stefan Zweig's work to exceed its original will be considered.
\end{abstract}

Key-words: translation; social representations; culture; ideology. 


\section{ÍNDICE DE ILUSTRAÇÕES}

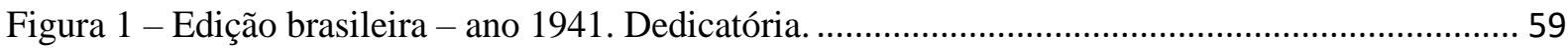

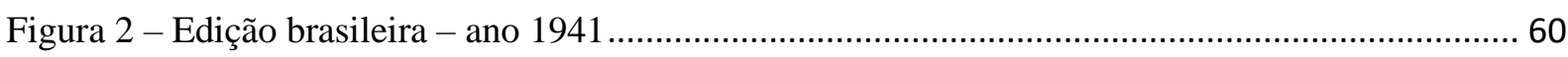

Figura 3 - $1^{\text {a }}$ Edição brasileira - ano 1941 - citada na obra de Dines. ................................................. 61

Figura 4 - Edição em língua inglesa - ano 1942 - publicada na Grã Bretanha................................... 62

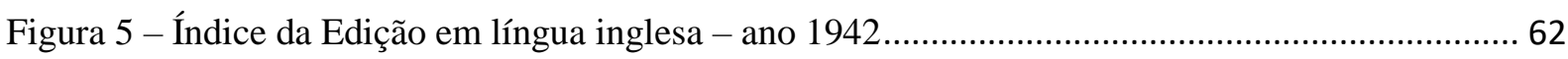

Quadro 1 - Descrição da característica física e da personalidade do brasileiro.................................... 64

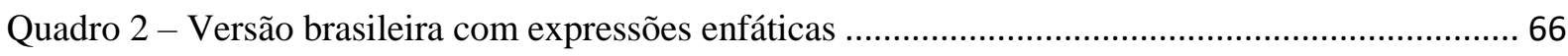

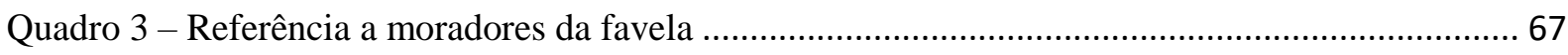

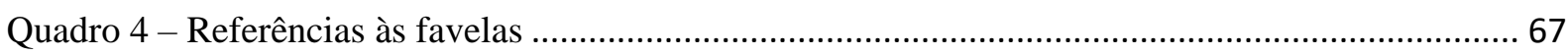

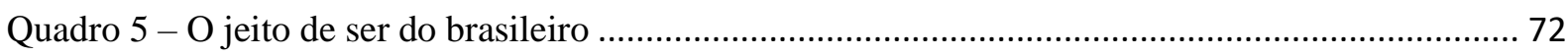




\section{SUMÁRIO}

INTRODUÇÃ

CAPÍTULO 1 - UMA LUZ PARA A MEMÓRIA ........................................................................ 8

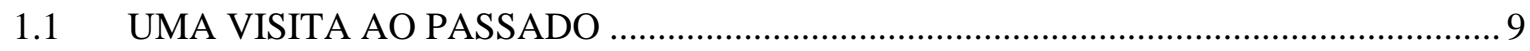

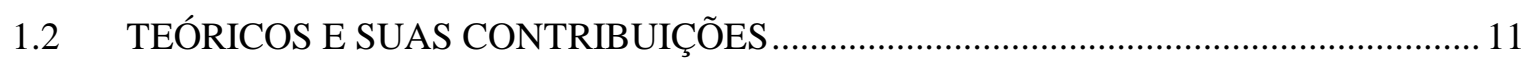

CAPÍTULO 2 - TEORIA DAS REPRESENTAÇÕES SOCIAIS - APORTE TEÓRICO .........21

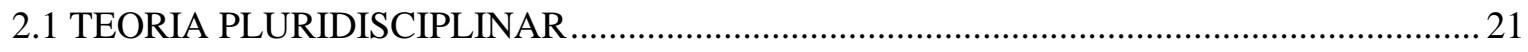

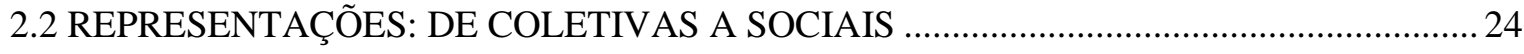

2.2.1 O homem e a necessidade de comunicação ...................................................................................29

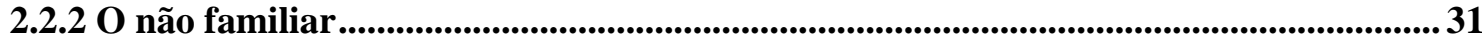

2.3 PROCESSOS QUE GERAM REPRESENTAÇÕES: ANCORAGEM E OBJETIVAÇÃO.... 34

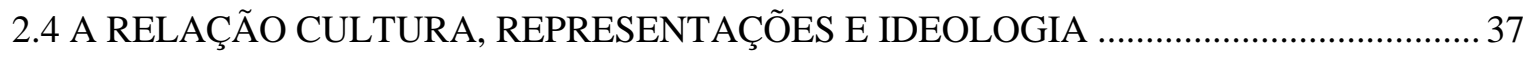

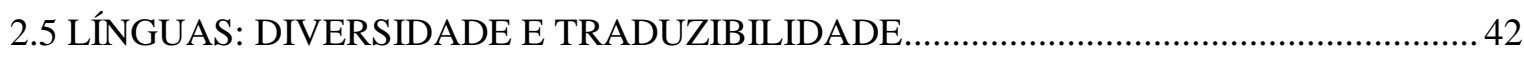

CAPÍTULO 3 - TRADUÇÃO EM CONTEXTO IDEOLÓGICO ...................................................45

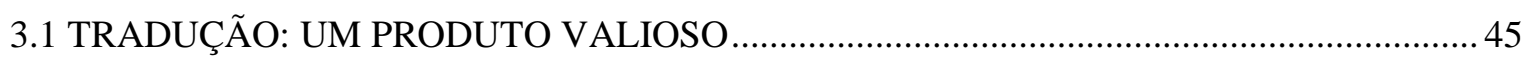

3.2 TRADUÇÃO PARA A PROMOÇÃO DE MUDANÇAS NA SOCIEDADE …........................ 47

3.3 TRADUÇÃO EM CONTEXTO IDEOLÓGICO - ERA VARGAS (1930-1945) ......................50

3.3.1 A tradução como instrumento de manifestação ........................................................................54

3.4 AUTOR DE ORIGEM JUDAICA E SUA OBRA NO ESTADO NOVO ................................56

3.4.1 O olhar de Zweig - um desafio para os tradutores ...............................................................63

3.4.2 Os ecos das representações em Brasil, país do futuro .......................................................70

3.4.3 Quando a tradução supera o original ............................................................................... 75

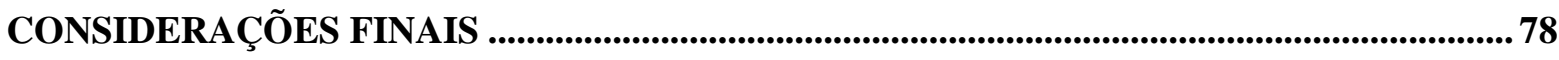

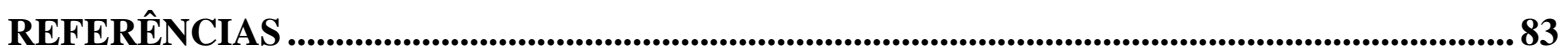




\section{INTRODUÇÃO}

A presente dissertação tem como intuito um estudo da tradução como produto diante de contextos em que estão envolvidas representações sociais e ideologia. Portanto, foram definidos como objetivos gerais:

- Destacar concepções relacionadas à tradução, ao papel do tradutor e aos fatores envolvidos em um processo tradutório, sob a perspectiva da Teoria das Representações Sociais de Serge Moscovici e da tradução em contexto ideológico;

- Estruturar uma compreensão de tradução como produto, decorrente de uma ação habilidosa do tradutor dentro de universos, os quais são constituídos de particularidades tão diversificadas.

Quanto aos objetivos específicos, este estudo se propõe a:

- Reconhecer o movimento da tradução por meio de sua história;

- Identificar o trânsito do tradutor entre culturas;

- Compreender a importância das representações sociais em um processo tradutório;

- Interpretar o poder da tradução para a transformação social.

A tradução, em seu papel como instrumento de mudança em uma sociedade, devido à complexidade de elementos envolvidos em seu processo tradutório, com a qual o tradutor, habilidosamente, precisa contornar em seu movimento entre culturas, além de ter que lidar com as determinações sociais existentes nos dois universos em que estão inseridos tanto o texto fonte como o texto alvo, exige do tradutor muito estudo e pesquisa para estabelecer uma estratégia tradutória. Pensa-se na utilização do termo "estratégia", no decorrer desta dissertação, com o sentido de passos a serem definidos para a execução de uma ação.

É fato que o trabalho do tradutor está sujeito a muitas influências e uma delas, de fundamental importância para sua decisão em definir estratégias para a execução da atividade tradutória, está relacionada às culturas que permeiam os contextos inseridos no processo tradutório. Destacam-se, também, as características linguísticas pertinentes a cada uma das línguas, que identificam uma sociedade específica e determinam uma época. O tradutor e o autor, com suas concepções, valores, crenças e visão de mundo constituem elementos importantes nesse processo.

O que possibilita a tradução estar presente em todas as línguas é a necessidade do homem em interagir e familiarizar-se com tudo que está ao seu redor. Para Paz (1981, p.10), “A tradução introduz o 'outro' em sua forma mais radical e estranha: a linguagem”. Assim, por ser a linguagem uma capacidade natural que o homem tem de exercer a sua comunicação, 
com possibilidades de realizá-la de várias formas, em diferentes línguas, compreende-se o fato de Batalha e Pontes Jr (2007: p.15) citarem Derrida e Paz, que colocam a tradução no centro da atividade humana, responsável pelo avanço das civilizações. Esta afirmação conduznos ao entendimento de que as traduções, independente de como possam ser qualificadas, se boas ou se ruins, deram e continuam dando suas contribuições para a abertura de mundos desconhecidos, para o enriquecimento cultural e para o desenvolvimento científico e tecnológico de muitos povos.

Britto (2010, p. 136), no artigo $O$ tradutor como mediador cultural, discorre que "traduzir é um processo de mediação bem complexo, que necessariamente envolve um grau elevado de manipulação". Portanto, quando se trabalha com tradução, é preciso ter a percepção de que não é simplesmente passar um texto de uma língua $\mathrm{X}$ para uma língua $\mathrm{Y}$, usando palavras ou expressões equivalentes, mas é preciso atentar-se à dimensão de abrangência de sentidos de cada palavra ou expressão, porque "a palavra está sempre carregada de um conteúdo ou de um sentido ideológico ou vivencial" (BAKHTIN, 2010, p.99). Por conseguinte, em seu envolvimento com culturas distintas, o tradutor deverá interpretar o peso de cada termo ou de expressões dentro das culturas envolvidas e o contexto temporal específico, tanto na língua-fonte como na língua-alvo, para elaborar seu texto de forma que alcance seu leitor nos objetivos propostos para sua tradução.

O texto original, quando escrito num passado mais distante, apresenta tantos valores morais, sociais e políticos preconizados dentro de certa cultura, assim como uma linguagem constituída de termos e de expressões que caracterizam o falar de determinadas classes dessa época. $\mathrm{O}$ ato tradutório, além de requerer do profissional de tradução muita pesquisa, estudo e bons dicionários necessários para tomadas de decisões, também requer muita sensibilidade e uma esmerada capacidade interpretativa. Oustinoff (2011) cita Dominique Wolton, que reforça esse posicionamento quando ressalta particularidades que envolvem as línguas e que são importantes para análise e consideração do tradutor:

Uma língua não é apenas um conjunto de palavras, é também e sobretudo uma maneira de pensar, de sonhar, de imaginar, de ver o mundo. Não fazemos as mesmas associações de ideias, as mesmas construções mentais, os mesmos raciocínios de uma língua para outra (WOLTON 2003, apud OUSTINOFF, 2011, p.127).

Saussure (2006, p.85), por sua vez, ressalta que "a qualquer época que remetemos, por mais antiga que seja, a língua aparece sempre como uma herança da época precedente". No que diz respeito ao fato de ser transmitida pelas gerações anteriores, assume características 
e sentidos próprios de um povo por ser "produto social da faculdade de linguagem e um conjunto de convenções necessárias adotadas pelo corpo social para permitir o exercício dessa faculdade nos indivíduos" (SAUSSURE, 2006, p. 17).

O tradutor encontra-se envolvido com elementos fundamentais da comunicação. Como a comunicação é um processo cultural, porque "a linguagem humana é um produto da cultura" (LARAIA, 2009, p.52), temas como língua, linguagem e cultura serão abordagens importantes para o desenvolvimento deste estudo. No que diz respeito à cultura, muitos estudiosos e pesquisadores têm, no decorrer de um processo histórico, defendido seus pensamentos na tentativa de conceituá-la. Cultura tem sido mote de pesquisas de áreas como Antropologia, História, Sociologia, Comunicação e mais algumas outras, muito embora com objetivos e aplicação diferenciados.

Com base na perspectiva de Laraia (2009, p.25), no final do século XVIII, o termo germânico Kultur era utilizado para simbolizar todos os aspectos espirituais de uma comunidade, enquanto que o termo francês Civilization referia-se, principalmente, às realizações materiais de um povo. Edward Tylor (1832-1917) sintetizou esses dois termos no vocábulo inglês Culture, que abrange conhecimentos, crenças, arte, moral, leis, costumes ou qualquer outra capacidade ou hábitos adquiridos pelo homem como membro de uma sociedade.

Os seres humanos não foram criados para viverem isolados e, por outro lado, também compartilham um espaço que se apresenta em constante transformação. Portanto, têm necessidade de se situarem neste mundo que os cerca, com toda a herança cultural, valores sociais e afetivos que os diferem como seres únicos, em processo permanente de inter-relação. É diante dessa ação comunicativa do indivíduo com seus pares que o processo de construção de representações é gerado.

Por serem esses passos importantes para o entendimento da abordagem das representações sociais dentro do processo tradutório, o embasamento teórico deste estudo está pautado na Teoria das Representações Sociais, de Serge Moscovici (2003). Psicólogo social romeno, radicado na França, voltou sua pesquisa para os fenômenos mais dinâmicos e cotidianos, procurando reavaliar a importância do social sobre o indivíduo para compreender melhor os vínculos estabelecidos entre eles. Como explica Guareschi e Jovchelovitch, “é quando as pessoas se encontram para falar, argumentar, discutir o cotidiano, ou quando elas estão expostas às instituições, aos meios de comunicação, aos mitos e à herança histórico- 
cultural de suas sociedades, que as representações sociais são formadas" (GUARESCHI; JOVCHELOVITCH, 2013, p.20).

A escolha da Teoria das Representações Sociais como aporte teórico justifica-se pelo fato de ela apresentar uma abordagem pluridisciplinar, dentro de um campo no qual a cultura tem fundamental importância nos estudos relacionados à formação e à dinâmica das representações. A cultura é um resultado das representações geradas pelos conhecimentos articulados, compartilhados e constituídos em contextos sociais.

Quando as representações sociais se tornam objetos de análise dentro do estudo da tradução como produto, como não pensar que o tradutor, além de trabalhar com um olhar para as representações existentes, precisa considerar as suas próprias, as que carrega consigo como herança cultural? As interpretações e as escolhas feitas pelo tradutor, que irão compor o texto para a língua meta, inevitavelmente, abrirão espaços para um movimento que favorecerá a geração de novas interpretações e novos compartilhamentos. Rodrigues (2000), em seu artigo Tradução: a questão da equivalência, afirma que,

\begin{abstract}
se a cultura não é fonte das representações, mas seu efeito; se a representação não domina nem oculta o referente, ela cria e interpreta esse referente, sem oferecer um acesso imediato a ele, o tradutor não lida com uma "fonte", nem com uma "origem" fixa, mas constrói uma interpretação que, por sua vez, também vai ser movimento e desdobrar-se em outras interpretações. (RODRIGUES, 2000: p. 97)
\end{abstract}

As representações revelam como uma determinada sociedade, em uma época qualquer, faz a sua leitura de mundo com base nas origens de suas constituições e da forma como foram firmadas pelo senso comum. O ponto de partida de suas constituições pode ser de origens ideológicas, filosóficas ou outras, porém são estabelecidas pelos pensamentos de grupos de classes privilegiadas e das grandes massas. Minayo (2013 apud GUARESCHI; JOVCHELOVITCH, 2013, p. 91) escreve:

\footnotetext{
Ainda que algumas formas de pensar da sociedade sejam abrangentes como um cimento que mantém as suas estruturas de dominação, cada grupo social faz da visão abrangente uma representação particular, de acordo com a sua posição no conjunto da sociedade. Essa representação é portadora também dos interesses específicos desses grupos e classes sociais (MINAYO, 2013 apud GUARESCHI; JOVCHELOVITCH, 2013, p. 91).
}

Tendo em vista que o processo tradutório pode ser cerceado para que o produto atenda a determinados fins, é possível que nem sempre o tradutor, ao aceitar essa missão, terá a liberdade de fazer escolhas para uma interpretação etnocêntrica. Então, com o propósito de destacar fatores que determinam elementos limitadores para o tradutor, será feito um recorte, 
dentro da História do Brasil, para uma abordagem sobre a ideologia da "Era Vargas" e a influência das representações sociais. Também a tradução com finalidade para o desenvolvimento de uma sociedade não será excluída das observações a serem apresentadas.

Ao ser pensado em uma relação da tradução com as representações, logo foi percebido que o tradutor precisa ser, realmente, um grande artista para assumir um ofício que requer muito de si. Traduzir não é apenas ter fluência nas línguas envolvidas, mas possuir um impressionante cabedal de informações, além da habilidade de lidar com as amarras convencionais externas que limitam seu campo de ação.

A motivação para a elaboração do estudo proposto apoia-se na hipótese de que reflexões possam conduzir a espaços infinitos, com o objetivo de fomentar discussões que viabilizem mais entendimento dessa abrangência de cuidados e conhecimentos relacionados à lida do tradutor. A tradução, portanto, é “o lugar de múltiplas determinações e efeitos linguísticos, culturais, institucionais, políticos" (VENUTI, 1992, apud RODRIGUES, 2000, p.92). No entanto, como traduzir de maneira que não sejam elaboradas traduções excessivamente estrangeirizadas ou domesticadas?

Entre os teóricos, sejam eles partidários da letra ou do sentido, observa-se que haverá sempre dicotomias relacionadas à tradução, tais como: letra/sentido, literal/livre, perda/ganho, teoria/prática, fonte/alvo, original/tradução, dentre outras. Fernandes (2012), em seu artigo Entre o estrangeiro e o leitor: Quintana e a tradução, escreveu que, embora a fidelidade ao original tenha sido desejável por muito tempo na tradução, o que faz o texto realmente ganhar em sentido é o poder de recriação concentrado na tradução.

A observação dos aspectos abordados anteriormente induz, ainda, a alguns questionamentos que instigam e se tornam motes para o estudo proposto:

- Como lidar com as culturas envolvidas na ação tradutória, considerando que há nelas representações constituídas socialmente, que marcam o pensar das sociedades em que estão inseridos o autor, o tradutor e os leitores a quem se destina a tradução?

- Que cuidados o tradutor precisa considerar para não extrapolar em uma tradução excessivamente estrangeirizada ou domesticada?

- Em relação aos fins aos quais se destina, quais são as influências que a tradução pode exercer sobre uma sociedade?

Neste trabalho, concepções relacionadas à tradução, ao papel do tradutor e aos fatores envolvidos em um processo tradutório serão destacados, com o objetivo de estruturar uma 
compreensão de tradução como produto, decorrente de uma ação habilidosa do tradutor, dentro de universos que são constituídos de particularidades tão diversificadas.

Para justificar e exemplificar as abordagens em relação à tradução como produto quando os contextos estão condicionados à ideologia e a outros fatores, será analisada a tradução da obra Brasilien ein land der zukunft, de Stefan Zweig, escritor e tradutor, a qual, em língua portuguesa, foi intitulada Brasil, país do futuro. Alguns posicionamentos críticos, assim como registros apresentados por Alberto Dines em suas duas obras biográficas, intituladas Morte no Paraíso - A tragédia de Stefan Zweig (2012) e Stefan Zweig - No País do futuro. A Biografia de um livro (2009), constituirão fontes para o presente estudo. Uma visão do contexto histórico vivido por esse escritor, em um país de governo ditatorial, tem a sua importância para a compreensão das interrogações que persistem, até hoje, sobre a sua relação com o governo Vargas.

Portanto, para uma melhor compreensão de como está distribuído o presente estudo, os tópicos abordados foram organizados da seguinte forma:

- Introdução $\rightarrow$ uma apresentação dos objetivos do estudo, justificativa e uma abordagem dos temas a serem desenvolvidos;

- Capítulo $1 \rightarrow$ "Uma luz para a memória" apresenta uma breve abordagem sobre a questão “tradução". Dois subitens serão desenvolvidos. Em 1.1, "Uma visita ao passado", abordará os primórdios da tradução; em 1.2, "Teóricos e suas contribuições", serão evidenciados alguns teóricos da História da Tradução e as suas práticas tradutórias;

- Capítulo $2 \rightarrow$ Teoria das Representações Sociais (TRS), de Serge Moscovici - A tradução é um produto com capacidade de gerar mudanças nos contextos sociais. Para compreender como ocorre esse processo, tal teoria foi escolhida para ser o aporte teórico deste trabalho, pelo fato de estudar as representações constituídas por meio da comunicação dos indivíduos, em seus contextos sociais. Esse capítulo encontra-se dividido em subitens: teoria pluridisciplinar; representações: de coletivas a sociais; o homem e a necessidade de comunicação; o não familiar; processos que geram representações: ancoragem e objetivação; a relação: cultura, representação e ideologia; e línguas: diversidade e traduzibilidade.

- Capítulo $3 \rightarrow$ Tradução em contexto ideológico - No capítulo em destaque, a tradução será abordada como produto em determinados contextos. O capítulo apresenta subitens que, em relação à tradução, discorrerão a respeito de quando os fins prevalecem e interferem na escolha de estratégias para o desenvolvimento do ato tradutório; sobre o seu propósito em privilegiar interesses ideológicos ou outros; a sua relação com o poder no âmbito político, 
econômico e social; e o seu papel como agente formador de representações. A versão em português, Brasil, país do futuro, da obra de Stefan Zweig Brasilien ein land der zukunft, e o período da história do Brasil, conhecido como Era Vargas, serão objetos de análise.

- Considerações Finais - Uma reflexão sobre as questões destacadas neste estudo e as conclusões geradas serão apresentadas com a esperança de que possam contribuir para novas pesquisas sobre a tradução como produto.

Em termos de metodologia de pesquisa, foi feita a abordagem qualitativa, sob a forma de análise de paratextos, dado que a natureza do tema não requer métodos e técnicas estatísticas, mas interpretação e atribuição de sentido em procedimento dissertativo. Como recorte para o objeto em estudo, foi definido o período denominado "Estado Novo", no qual a ideologia propagada e as restrições impostas pela esfera política impactaram fortemente a sociedade e a produção cultural dessa época. 


\section{CAPÍTULO 1 - UMA LUZ PARA A MEMÓRIA}

Dentro da perspectiva do desenvolvimento do tema da dissertação, serão revistas algumas teorias relacionadas ao processo tradutório nos Estudos da Tradução, para embasamento das questões relativas ao estudo proposto. Os aspectos que circundam o autor e a sua obra, o próprio tradutor e a sua tradução são considerados de grande importância para o profissional de tradução na elaboração de um texto para a língua de chegada, pois se faz necessário criar estratégias precisas para os objetivos propostos.

A tradução é a interação entre duas línguas, por meio da qual uma mesma obra, "o original", pode se fazer presente em outras culturas com línguas diferentes que não teriam acesso aos pensamentos do "original” sem esse processo. A tradução não está para substituir o original, mas para completá-lo. O tradutor, ao interpretar o texto original, precisa entender o que o autor quis dizer, a sua intencionalidade para levar o sentido à língua de chegada. Quando se tem a visão de que as diferenças linguísticas e culturais são marcantes entre a língua fonte e a língua alvo e, com isso, a percepção de que não conseguirá levar o mesmo sentido ou o mesmo efeito ao leitor da tradução, o tradutor tem como opções apagar as diferenças e adaptar o texto à cultura de chegada para evitar o estranhamento, isto é, a não familiarização com o texto. $\mathrm{O}$ tradutor faz uso de sua habilidade e de estratégias tradutórias para apresentar o "estrangeiro" ao leitor da língua de chegada, de maneira que este possa interagir com outras culturas, ampliando seus horizontes, sem deixar de ter as mesmas experiências que o leitor do original.

Para Cândido (1995), esse contato do leitor com o mundo das obras literárias é um fator de humanização. Infere que

Confirmam no homem aqueles traços que reputamos essenciais, como o exercício da reflexão, a aquisição do saber, a boa disposição para com o próximo, o afinamento das emoções, a capacidade de penetrar nos problemas da vida, o senso da beleza, a percepção da complexidade do mundo e dos seres, o cultivo do humor. A literatura desenvolve em nós a quota de humanidade na medida em que nos torna mais compreensivos e abertos para a natureza, a sociedade, o semelhante. (CÂNDIDO, 1995, p.249)

O leitor, quando procura uma obra, o faz já sabendo o que espera dessa literatura, porque a considera uma porta aberta para um mundo de viagens fantásticas, de vivências de emoções inusitadas e de descobertas inesperadas, que o induz a mergulhar em seu mundo interior para reflexões, não somente dando-lhes condições de reavaliar seus valores e sua visão de mundo, bem como ampliar seus conhecimentos. 
Ainda hoje, não há um consenso quanto ao status da tradução e aos critérios para a sua ação tradutória, embora a tradução seja uma prática tão antiga quanto a Torre de Babel, como cita Gentzler (2009, p. 21). Em outras palavras, a ausência de um consenso significa que os teóricos, estudiosos da tradução, ainda não conseguiram estabelecer um comum acordo a respeito do seu objetivo, de suas regras e de sua importância. A divergência evidenciada através dos tempos, que não exclui os estudiosos da atualidade, assegura que há muitos espaços para discussões, hipóteses a serem levantadas, bem como constatações novas, abrindo caminho para teorias ainda não divulgadas para alegria e realização de todos os apaixonados pelos estudos da tradução.

No que diz respeito a uma abordagem a determinados tipos de pensamentos sobre tradução, não há como deixar de fazer uma retrospectiva histórica com o propósito de ampliar o entendimento de como o papel e a função da tradução têm passado por mudanças. Não pretendemos fazer um estudo da história da tradução, mas levantar alguns pontos de como o processo e o produto têm sido abordados em relação às culturas existentes em contextos temporais diferentes.

\subsection{UMA VISITA AO PASSADO}

Nos estudos realizados sobre tradução, verificou-se que é uma atividade muita antiga, com estudos que evidenciam os primeiros traços de tradução cerca de três milênios antes da era cristã, na Ásia Menor. Nas antigas civilizações, os escribas exerciam um trabalho especializado com funções relativas ao ensino, à escrita e à tradução. De acordo com Mauri Furlan (2003, p.11-28), em seu artigo Brevíssima história da teoria da tradução no Ocidente: I. Os Romanos, a primeira época da tradução literária ocidental consiste em traduções do grego para o latim. Um escravo grego alforriado, de nome Lívio Andrônico, é reconhecido como o primeiro tradutor europeu e foi quem elaborou uma versão latina da Odisseia, em 240 a. C.

Foram Horácio e Cícero, porém, que abriram margens para as reflexões sobre o papel do tradutor e as traduções. Quando Bassnett (2005, p.68) escreve sobre a arte de Horácio e Cícero, deixa evidente a quem o olhar desses dois tradutores era destinado:

a arte do tradutor, para Horácio e Cícero, portanto, consistia na interpretação cuidadosa do texto em LF, de modo a produzir uma versão em LM baseada no princípio non verbum de verbo, sed sensum exprimere de sensu (de expressar não palavra-por-palavra, mas o sentido), e sua responsabilidade era para com os leitores da LM (grifo nosso) . 
Horácio e Cícero, por meio de suas traduções, não apenas deixaram suas impressões sobre a atividade tradutória, como influenciaram gerações e gerações de tradutores.

São Jerônimo, considerado o santo dos tradutores, também apresentou sua preferência pela tradução do sentido num período em que a tradução dos textos sagrados poderia levar o tradutor a uma condenação pela Inquisição. Nesse caso, fazendo referência a uma metáfora, podemos dizer que, nos estudos de tradução o pensar diferente significa colocar mais "lenha na fogueira" para manter a chama que aquece os ânimos e, assim, nas divergências existentes, provir de contribuições para as discussões que possam abrir espaços para novas propostas de pensamento. Sejam os teóricos partidários da letra ou do sentido, observa-se que haverá sempre dicotomias relacionadas à tradução. Lépinette (2004), em seu artigo, faz referência a Steiner, o qual afirma serem as perguntas sobre traduzibilidade, tradução livre versus literal, letra versus espírito etc. as mesmas, repetindo-se ao longo da história e seguindo na atualidade.

Os discursos estão sempre em busca de um conceito único de tradução e de critérios que normatizem o ato tradutório, não levando em consideração o fato de o espaço da tradução ser irremediavelmente plural, heterogêneo e não unificável (BERMAN, 2009, p. 344). O ponto que chama a atenção em Berman é que, por um lado, mesmo se opondo à normatividade, ele propõe uma reflexão da tradução sobre ela mesma, com o nome de "tradutologia", na qual estabelece ações para o procedimento dessas reflexões, em que nomeia de "tarefas de uma tradutologia". Por outro lado, com sua proposta, deixa evidente que o importante para as reflexões em referência é que seja considerado o contexto histórico de como cada cultura estabelece para si o que seja tradução, para ser feita a análise com outros discursos existentes. Para Berman (2007), a tradução é

\footnotetext{
Experiência. Experiência das obras e do ser-obra, das línguas e do ser-língua. Experiência, ao mesmo tempo, dela mesma, da sua essência. Em outras palavras, no ato de traduzir está presente um certo saber, um saber sui generis. A tradução não é nem uma sub-literatura (como acreditava-se no século XVI), nem uma sub-crítica (como acreditava-se no século XIV). Também não é uma linguística ou uma poética aplicada (como acredita-se no século XX). A tradução é sujeito e objeto de um saber próprio (BERMAN, 2007, p. 18).
}

Para Berman, o produto de um processo tradutório traz em si essências de tudo o que está envolvido nessa ação. O tradutor precisa imergir no contexto do autor e no de sua obra para conhecer os seus valores, entender a sua forma de olhar o mundo que o cerca, os sentimentos e as emoções que ele deseja transmitir em seu texto. Um estudo aprimorado das 
línguas envolvidas em suas diferenciações linguísticas se faz presente nesse processo, sem deixar de considerar os contextos culturais pertinentes. Portanto, é possível entender que o resultado de uma tradução é um produto que apresenta o original de uma forma própria, com uma alma nova, que lhe proporciona uma sobrevida.

A abordagem da tradução em seu contexto histórico será uma estratégia a ser apresentada a seguir, com o propósito de destacar como se pensavam a tradução e a sua repercussão no contexto de alguns séculos atrás. $O$ propósito não será seguir, necessariamente, uma linha de tempo contínua, mas tomar como referência os volumes 1 e 2 dos Clássicos da Teoria da Tradução, editado pela Universidade Federal de Santa Catarina UFSC, em 2014, os quais permitirão destacar as ideias recorrentes, em temporalidade diversificada, sobre tradução. Outras abordagens foram acrescentadas tendo como aporte bibliografias também diversificadas, selecionadas para o enriquecimento do trabalho.

\subsection{TEÓRICOS E SUAS CONTRIBUIÇÕES}

A maneira de bem traduzir de uma língua para outra é o texto de Etienne Dolet (1509-1546), escrito em 1540. Esse autor, humanista e editor francês, pelo fato de suas publicações audaciosas terem sido vistas à contramão dos dogmas religiosos preconizados no período, foi condenado e salvo pelo perdão do rei em algumas circunstâncias. Porém, posteriormente, não teve como escapar de uma pena de morte. $\mathrm{Na}$ época, a tradução era um interesse do Estado e um problema de religião, com representações dominantes.

De acordo com Bassnett (2005, p. 78), o ponto de vista de Dolet foi reiterado por George Chapman (1559-1634), reconhecido tradutor de Homero, quando se ressalta que um tradutor deve evitar a tradução palavra-por-palavra, compreender o "espírito do original", evitar traduções muito livres, baseando-se em uma consistente investigação acadêmica. Para Dolet, ao criar e ao apresentar as suas considerações, normatizando critérios para o processo tradutório, estava nítido o seu cuidado com as traduções, pois acreditava em seu papel na construção e no estabelecimento da língua vernácula francesa.

Nicolas Perrot DÁblancourt (1606-1664), tradutor e autor de obras em prosa, era considerado por Voltaire como "um tradutor elegante", cujas traduções foram chamadas de “belles infidèles" por Gilles Ménege (1613-1692), por se afastarem muito dos textos originais. Na introdução de sua tradução Tratados e diálogos de Luciano, de 1664, ele já apresenta as explicativas de suas estratégias de tradução e alega que as mudanças em relação à ideia 
central de um texto são justificadas por serem em defesa do culto ao belo, à apologia da elegância. Em seus argumentos, observa-se uma preocupação em fazer adequações à cultura de chegada, com a alegação da intraduzibilidade ou da falta de entendimento e de incompatibilidade com os costumes da sociedade francesa. Era uma tática de D’Ablancourt apresentar as justificativas de suas estratégias de tradução nos prefácios de suas obras e essas adequações agradavam àqueles que enfatizavam a preservação dos valores e bons costumes da sociedade. Milton cita que "os eruditos consideravam as traduções livres de D'Ablancourt não como uma traição, mas como um serviço que ele lhes prestava" (MILTON, 2010, p.83). Aqui, o serviço prestado era em função de manter a língua francesa em um patamar superior em relação à sua importância e à supremacia linguística.

D’Ablancourt, em seu estilo característico, não fugia do modo de traduzir de outros de sua época, definida por Balliu (1995, p. 17) como "imitação à distância"1. A expressão consiste em definir a tradução com adaptações e adequações, seguindo as normas do "bom gosto" da erudição da época.

Com o aporte dos estudos de Bassnett (2005, p. 83- 88), na Inglaterra do século XVII, destaca-se Sir John Denham (1615-1669), que diz ser tarefa do tradutor "extrair o que considerar o núcleo essencial da obra e reproduzi-la ou recriá-la na língua-meta”.

John Dryden (1631-1700), por sua vez, numa tentativa para resolver os problemas da tradução, estabeleceu três formas para a opção do tradutor:

I - Traduzir, de uma língua para outra, palavra-por-palavra e linha-por-linha (metáfrase);

II - Fazer uma tradução com liberdade de escolha, pelo sentido, assim como

Cícero (paráfrase);

III - Abandonar o texto do original quando considerar adequado (imitation).

Dos critérios apontados, a preferência de Dryden foi pela paráfrase, desde que haja determinados critérios.

Embora ele tenha apresentado uma maior flexibilidade para o tradutor fazer suas escolhas, não deixa de representar um propósito de normatização de critérios para tradução. Quando se pensa em paráfrase, pensa-se em abrir mão da impressão original, e não preservar o modo como o escritor expressa-se em sua língua.

Nas citações feitas até então, a tradução é apresentada com suas dicotomias letra/sentido, literal/livre, perda/ganho, teoria/prática, fonte/alvo, original/tradução, as quais

\footnotetext{
1“La imitación de los Antiguos es una imitación a distancia, basada en la perfecta adecuación entre estilo y época” (BALLIU,Christian, 1995).
} 
foram destacadas no início desse capítulo. Portanto, é perceptível que elas sempre estiveram na preocupação dos importantes nomes envolvidos com a tradução nos séculos passados e que elas perduram até os nossos dias, o que possibilita uma compreensão de sua grande importância para a continuidade e a difusão das culturas e, assim, contribuindo para o desenvolvimento das civilizações.

Por meio de um contexto histórico de práticas tradutórias, o tradutor tem encontrado, ao mesmo tempo, exigências diversas e possibilidades de recursos para atender às necessidades do leitor da língua de chegada. De qualquer forma para Rónai (1976, p. 4), a ação de "conduzir uma obra estrangeira para outro ambiente linguístico significa querer adaptá-la ao máximo aos costumes do novo meio, retirar-lhe as características exóticas, fazer esquecer que reflete uma realidade longínqua, essencialmente diversa”.

Desde a tradução da Bíblia de Martinho Lutero (1530), que, por sinal, deu início ao processo de formação de uma língua alemã padronizada, a tradução mantém-se como grande influência na literatura alemã. Em seu artigo para o bacharelado com ênfase em Estudos da Tradução, da Universidade Federal do Paraná, de título Sobre os diferentes métodos da tradução: a tradução no contexto político-pedagógico da Bildung, Caio Heleno da Costa Pereira (2008) apresenta uma ampla visão sobre o assunto, a qual enriquece o que está sendo abordado. Ele afirma que pensar a tradução como meio para o enriquecimento da língua nacional significa o mesmo que situar a tradução muito próxima do centro de toda questão social e política. Cita, como exemplo, a tradução feita por Lutero da Bíblia, com uma linguagem não para os eruditos, mas para alcançar a grande massa e trazer o homem cristão à leitura dos evangelhos.

Lutero, tido por Deslile e Woodsworth (1998, p. 38) como “o artesão da Língua Alemã", além de ter traduzido a Bíblia de uma forma que alcançou uma multidão, acabou promovendo grandiosamente a religião e, assim, estabeleceu a base para a padronização da escrita da língua alemã. Dessa forma, foram sendo constituídas, também, as bases para a futura literatura nacional com traduções de obras de línguas diversas, trazendo o "estranho" e sua cultura para o enriquecimento da língua de chegada.

De acordo com Milton (2010),

Do "contato de muitas faces com o estranho", no começo obras clássicas, e depois obras inglesas, espanholas, francesas e italianas, a literatura alemã desenvolveria suas próprias qualidades. Segundo August Wilhelm Schlegel, tomaria o melhor de outras literaturas e, ao mesmo tempo, confirmaria sua própria independência (MILTON, 2010, p. 85). 
O que Milton ressalta é que o contato, por meio da tradução, com obras de outras culturas, inclusive as obras clássicas, possibilita a filtragem de tudo a ser considerado relevante, seja em relação a contribuições linguísticas e a valores diversos, desde que se tornem fatores importantes na geração de mudanças e de transformação dentro do contexto de uma sociedade. Com o dinamismo particular de cada sociedade, toda essa influência conduz a uma autonomia e, consequentemente, à formação de uma identidade, à sua própria independência, reconhecida por um estilo próprio, único.

O papel do tradutor e seu ofício estão destacados nas obras de vários escritores alemães dos séculos XVIII e XIX, já que muitos foram tradutores. Dentre eles estão Wilhelm von Humboldt (1767-1835) e Friedrich Leopold, Barão de Hardengerg, mais conhecido como Novalis (1772-1801). Humbolt considera a tradução como uma maneira de proporcionar ao indivíduo experiências com as quais ele nunca teria tido contato e descreve o tradutor de uma forma especial. Sua obra é um referencial para o estudo da linguagem. O ser humano, em sua percepção, se compõe de tudo o que o cerca e de como ele está ligado à sua história.

Milton (2010, p. 86) afirma que Novalis chega a exaltar a tradução acima da escrita original quando diz que "traduz-se por verdadeiro amor ao belo e pela literatura da nação. Traduzir é produzir literatura, assim como escrever a própria obra de alguém - e é mais difícil, mais rara".

No trânsito entre os séculos XVIII e XIX, temos Friedrich Daniel Ernst Schleiermacher (1768-1834), que em seu ensaio Sobre os diferentes métodos de tradução, de 1813, já aborda uma opção de tradução pela qual o tradutor leva o leitor até o autor e seu original, numa tradução "distanciadora"; ou leva o autor e o texto original até o leitor, numa tradução "aproximadora/assimiladora". De acordo com Milton (2010, p. 92), a preferência de Schleiermacher está manifestada pela tradução difícil, na qual tenta reproduzir a forma do original, resultando em uma tradução que pareça estranha e diferente. Sua maneira de pensar a tradução influenciou gerações posteriores de tradutores, inclusive Walter Benjamin.

Benjamin (apud BRANCO, 2008, p.35) afirma que a tradução "consiste em encontrar na língua em que se está traduzindo aquela intenção por onde o eco do original pode ser ressuscitado". Para ele, a boa tradução, a verdadeira, precisa ser transparente, não sobrepõe o original, não o oculta, nem tira sua luz. A tradução proporciona a sobrevida do original.

Em um artigo de Mary Snell-Hornby, traduzido para a revista Pandaemonium (2012, 191), a autora postula que as duas alternativas também foram abordadas por Vermeer (1994, p.171) e que, para designá-las, emprega os termos "tradução distanciadora" e "tradução 
aproximadora (ou assimiladora)", reconhecendo, em ambas, as similaridades essenciais, apesar de contrapostas. No entanto, para Vermeer, as duas formas de tradução não infligem danos à cultura de partida pelo fato de o tradutor atuar de forma criativa nas duas. Portanto, superar dificuldades é uma arte.

A tradução, inegavelmente, tem mantido um papel de fundamental importância para o enriquecimento das línguas e das culturas. Uma abordagem que ilustra esse papel é feita por Delisle e Woodsworth (1998, p. 37), quando ressaltam que, em seus estudos, "a tradução não aparece como um fenômeno isolado, mas associada a certos projetos mais importantes, de natureza nacionalista, ideológica e religiosa, que tinham, muitas vezes, apoio de monarcas, aristocratas e instituições".

Desde o final da Idade Média, as traduções são analisadas como fundamentais para a formação das línguas e das literaturas nacionais de muitos países, inclusive a França, onde uma forte ideia de nacionalismo deu apoio às traduções de muitas obras estrangeiras. A Inglaterra também não pode ser esquecida, tendo em vista que influências estrangeiras também enriqueceram a língua e, consequentemente, "estimularam a necessidade de um idioma nacional” (DELISLE; WOODSWORTH, 1988, p. 37).

Nos Estados Unidos da América, nas primeiras décadas do século XX, a tradução ainda era considerada uma atividade sem muita expressão, sem criatividade, que não despertava grande interesse do público e da crítica. Porém, com o surgimento da primeira oficina de tradução em 1964 e com os investimentos feitos pela Fundação Ford para o estabelecimento do Centro Nacional de Tradução, no ano seguinte, estudos e publicações relativos a essa atividade passaram a contribuir para alavancar um pouco mais a tradução literária no país. Nas décadas de 70 e de 80 , ocorreu uma diminuição significativa neste avanço. De acordo com a perspectiva de Gentzler (2009) é que

\footnotetext{
O motivo para isso é, sem dúvida, a natureza monolíngue da cultura. Entretanto, essa tipificação também tem origens socioeconômicas: colocar na tradução o rótulo de derivativa acaba reforçando um status quo existente, que dá ênfase não ao processo, mas sim à busca e à consumação de significado "original" (GENTZLER, 2009, p.28).
}

Porém, sem deixar de considerar que a prática de tradução literária também era afetada por representações que norteavam sistemas de valor e pensamentos que dominavam o contexto tradutório da cada época ressaltada, nessa retrospectiva feita. Gentzler (2009, p.2829) complementa que 
a atividade de tradução representa um processo de antítese a certas crenças literárias dominantes, daí o fato de ser relegada a um status marginal nas instituições educacionais e econômicas e de sua posição nessa sociedade como parte de um movimento de contracultura.

Considerações também precisam ser feitas em relação ao fato de que a cultura norteamericana é muito nacionalista e suas crenças e seus valores são constituídos de representações históricas.

Um dos mais influentes estudiosos americanos de tradução é Lawrence Venuti, que escreveu dois importantes livros sobre a tradução, cujos títulos são: The Translator's Invisibility: A History of Translation, em 1995, e The Scandals of Translation: Towards an Ethics of Difference, em 1998. Venuti resgatou as nomenclaturas "domesticação" e "estrangeirização", apresentadas por Schleiermacher, e, com base no que os termos representavam, avalia que as traduções realizadas nos Estados Unidos não apenas incentivavam, como também reforçavam as crenças e as ideologias nacionalistas que norteavam a sociedade americana.

Dessa forma, com base nesses parâmetros, as traduções anglo-americanas apresentavam um padrão domesticante, no qual as adequações são feitas para atender a uma fluência de tradução ao leitor da língua alvo. Esse tipo de tradução apresenta um apagamento da cultura da língua de partida e, por outro aspecto, corrobora para a invisibilidade do tradutor de acordo com a teoria de Venuti. Quanto a "estrangeirizante", proporciona ao leitor uma experiência com o "estranho", colocando-o em contato com os elementos culturais e linguísticos do original, dando-lhe a percepção de que está ampliando e enriquecendo a sua visão de mundo quando é conduzido ao encontro com o autor, a sua obra e as particularidades da língua fonte.

Quanto ao que Venuti defende como tradução "estrangeirizante", Benedetti (2003) escreve no prefácio do livro Conversas com Tradutores: balanços e perspectivas da tradução:

Como então defender acriticamente o tipo de tradução que chamo aqui de permeável, tradução que no Hemisfério Norte se configura como de resistência à predominante tendência de "domesticação", se em nossa sociedade não existe essa tendência? Vivemos numa sociedade importadora de tecnologia e de cultura, que sofre o afluxo constante de terminologia e ideias estrangeiras, que produz muito menos do que traduz tanto na área literária, na técnica ou de ciências humanas; numa sociedade em que é preciso promulgar leis para impedir que seus próprios órgãos oficiais usem termos estrangeiros absolutamente dispensáveis. Defender sem reflexão uma corrente desse tipo, aqui, seria o mesmo que abrir as compotas para irrigar uma região inundada (BENEDETTI; SOBRAL (Orgs.), 2003, p. 29). 
A visão de Venuti para Benedetti está situada em um contexto cultural específico, a qual não seria compatível diante de outros que apresentam um mundo de diversidades, tanto no que diz respeito ao dinamismo cultural, quanto às inovações tecnológicas.

Por sua vez, Susan Bassnett faz referência a uma citação de Lotman, na qual ele ressalta esse dinamismo cultural ao afirmar que "tentativas de situar fases de desenvolvimento cultural dentro de uma divisão temporal estrita são incompatíveis com esse dinamismo" (Bassnett, 2005, p. 64). Realmente, diante de uma diversidade de contextos de uma determinada cultura, a precisão do tempo em que essas fases acontecem é complicada, pois essa diversidade apresenta particularidades específicas que diferenciam uma sociedade da outra. Os elementos que constituem essas particularidades estão suscetíveis a mudanças constantes devido ao processo dinâmico que ocorre nos contextos sociais. Batista (2010), em Reflexões sobre o conceito antropológico de cultura, promove uma interessante visão do que está sendo dito e cita que

\begin{abstract}
a cultura que diferencia os povos e uma nação da outra, é o que faz com que sejamos autênticos, pois somos produtos do meio e produtos para o meio, assim pertencemos a um processo coletivo e não individual onde nossas experiências cristalizadas entram em confronto com as novas e fazem com que o ser mais "culto" não seja isento de mudanças e evoluções (BATISTA, 2010, p.106).
\end{abstract}

Batista enfatiza que o homem é um ser coletivo por essência e que é moldado pelo meio em que vive, independentemente de ser letrado ou não, de toda maneira, as influências que o circundam são elementos que entram em conflito constante com as suas representações existentes, que interferem e, também, geram mudanças.

Para Meschonnic (1999, p. 13), “a tradução sempre tem um papel importante como meio de contato entre as culturas. A comunicação consiste na passagem de um enunciado de uma língua para outra" (tradução nossa). ${ }^{2}$ Não tem como se pensar em tradução sem associá-la às culturas que estão envolvidas em seu processo e na importância desse envolvimento para todos que estarão usufruindo de seu produto.

Arrojo (2007, p. 78) destaca a realidade desse trânsito entre culturas quando afirma que "cada tradução (por menor e mais simples que seja) exige do tradutor a capacidade de confrontar áreas específicas de duas línguas e duas culturas diferentes". Com base nos estudos de Wyler (2003, p. 30-31), percebe-se que diante da exigência desse confronto por parte dos tradutores, já no período do achamento do Brasil, a missão missionária precisou ter um

\footnotetext{
2 "La traduction depuis toujours tient une place majeure comme moyen de contact entre cultures. La communication y consiste à faire passer un énonce d'une langue dans une autre".
} 
entendimento das bases que sustentavam a cultura dos indígenas para poder estabelecer uma forma de comunicação e doutrinação. Dá-se, nesse período, o início das primeiras estratégias tradutórias e das primeiras traduções realizadas em terra brasileira.

Os jesuítas, que se encontravam a serviço da Coroa portuguesa e em missão de catequização, faziam o uso da tradução com objetivos cultural e de conversão dos nativos ao cristianismo. A doutrinação dar-se-ia pelo apagamento dos rituais pagãos dos índios para convertê-los à religião.

Wyler (2003, p. 36) afirma que o primeiro registro que inaugura a história da tradução no País é feito pela carta de Pero Vaz de Caminha ao rei de Portugal, onde descreve com detalhe o território, os habitantes, os atos de índios e de portugueses e até mesmo as justificativas desses atos, assim como relata o primeiro ato de tradução, com a utilização da mímica para a comunicação com os índios.

Os missionários jesuítas, como tradutores culturais, usavam técnicas de associação para transmitir uma relação dos conceitos novos com os que os nativos traziam em sua cultura pela reorganização dos significados para chegar a um sentido aproximado, uma equivalência. Não seria um processo que trabalha uma das equivalências defendidas por Nida, a dinâmica? Dentro da teoria de Nida, a equivalência dinâmica está baseada no "princípio do efeito equivalente". Gentzler (2009) ressalta que

\footnotetext{
Nida, com base em seu extenso trabalho de campo, que mostrava que a mensagem religiosa frequentemente deixava de ser comunicada por causa de diferentes contextos culturais e visões de mundo, compreendeu que o significado não pode ser separado da experiência pessoal e da estrutura conceitual da pessoa recebendo a mensagem. Concluiu que as ideias "devem ser modificadas" para se encaixar no mapa conceitual da experiência do contexto diferente (NIDA, 1960, p.87, apud GENTZLER, 2009, p. 80).
}

Na perspectiva de Nida, a tradução com base na equivalência dinâmica tem como objetivo fazer com que a mensagem traduzida possa ser semelhante à mensagem original, mas com a ciência de que a relação entre o receptor e a mensagem é a mesma existente entre a mensagem original e o seu leitor.

Há a possibilidade de considerar essa comparação, tendo vista que as técnicas de associação utilizadas buscavam traduzir conceitos novos, dentro de uma aproximação de equivalência para sua tradução na língua alvo. E esse processo só se tornou possível pela imersão por parte dos missionários no contexto cultural dos nativos, conquistando-lhes a confiança na interação social tribal. Porém, é importante ressaltar que o conhecimento 
adquirido do seu meio e de sua cultura, também contribuiu para que os padres catequizadores logo encontrassem meios específicos a serem utilizados para a eliminação dos rituais pagãos, tais como o canibalismo e a poligamia. Para se ter uma ideia das estratégias encontradas pelos missionários, Bosi (1992) cita que

O método mais eficaz não tardou a ser descoberto: generalizar o medo, o horror, já tão vivo no índio, aos espíritos malignos, e estendê-lo a todas as entidades que se manifestassem nos transes. Enfim, diabolizar toda cerimônia que abrisse caminho para a volta dos mortos (BOSI, 1992, p. 69).

Ousar dizer que se trata de mais uma técnica a ser considerada na tradução é fora de propósito, mas reconhecer que alcançou resultados, conforme a história apresenta, é um fato que não pode ser descartado como estratégia de ação tradutória dentro daquele contexto.

Por meio de práticas ricas de significados e pela busca de sentido em outro locus simbólico para proceder a uma correlação, num processo de mediação que pudesse favorecer uma melhor compreensão, os catequistas conseguiram aproximar os índios dos símbolos e ritos cristãos. Com os negros, trazidos do continente africano como mão de obra escrava, foram usados os mesmos procedimentos. Os negros foram trazidos de várias regiões do continente africano, onde vários dialetos eram falados, com cultos a entidades diversas. Portanto, a tática usada pelos jesuítas não deixa de ser um exemplo de ajustes à cultura alvo. Para enfatizar o que acaba de ser abordado, Elaine Indrusiak (2005, p. 130), em seu artigo $O$ papel dos estudos de tradução na busca pela identidade cultural latino-americana, relata que

(...) a premissa básica de que qualquer trânsito entre culturas se dá por meio de um processo tradutório, não necessariamente via tradução interlingual, mas sempre por meio de um movimento de busca de referenciais próprios para a compreensão de novas formas significantes.

A citação de Indrusiak dá sentido para a afirmação de Boss em relação à estratégia de tradução utilizada com os índios, pelos missionários, como sendo um meio de promover uma nova significação de valores, no caso, religiosos.

Nos estudos sobre tradução, percebe-se que, desde sempre, a atividade tradutória tem sido executada não só com base em fatores culturais das línguas alvo e fonte, mas também em fatores políticos, sociais, religiosos e ideológicos, que exigem movimentos subjetivos do tradutor para o uso de estratégias favoráveis de maneira a atender às expectativas em relação à tradução. 
As representações constituídas, que ditam o comportamento, o pensar, por melhor dizer, as normas que regem as sociedades sempre exerceram uma grande influência na questão relativa ao tipo de tradução a ser feita, palavra-por-palavra ou por sentido. Quando nos referimos à cultura, elemento importante para o tradutor em sua atividade, não podemos desvinculá-la das representações, já que são fatores ligados à sua formação e à sua dinâmica. Portanto, no próximo capítulo, será feita uma imersão na Teoria das Representações Sociais, de Serge Moscovici, para que não sejam destacadas, apenas, a sua formação e a sua dinâmica, mas a consideração quanto à importância de seu conhecimento nesse trânsito do tradutor entre culturas distintas. 


\section{CAPÍTULO 2 - TEORIA DAS REPRESENTAÇÕES SOCIAIS - APORTE TEÓRICO}

O capítulo a ser apresentado permitirá uma visão da importância dessa teoria e o propósito de sua escolha como aporte teórico para a condução das questões que constituem as diretrizes para o desenvolvimento deste trabalho.

\subsection{TEORIA PLURIDISCIPLINAR}

A Teoria das Representações Sociais constitui o aporte teórico para fundamentar o estudo proposto nesta dissertação por ela ser pluridisciplinar, pois está ancorada em parâmetros de várias áreas do conhecimento das Ciências Biológicas, Humanas e Sociais, como a Sociologia, a Antropologia, a História, a Economia, as Ciências Políticas e a Biologia. Cada uma delas tem o seu foco e a sua forma metodológica de fazer a sua abordagem, mas todas têm o homem e o seu comportamento como ponto de partida.

Quando, em questão, é o entendimento de como o tradutor, em seu ato tradutório, lida não apenas com as línguas envolvidas, mas com as culturas que ali se encontram e a sua própria bagagem cultural, não se pode esquecer que as decisões a serem tomadas poderão determinar a qualidade e de como será a aceitação de seu produto final, a tradução. Todas as estratégias consideradas constituem o sucesso da tradução, principalmente, quando esse produto está destinado a propósitos específicos dentro de determinados contextos sociais.

Venuti (1992, apud Rodrigues, 2000, p.92), citado na página 9 desta dissertação, por caracterizar a tradução como "o lugar de múltiplas determinações e efeitos" - linguísticos, culturais, institucionais, políticos", reforça a ideia de ser a tradução um produto com o poder de levar o leitor a interagir com outras culturas, transformar opiniões, fazer circular novos pensamentos e, assim, gerar novas representações. Esse poder inerente à tradução tem sido recorrido como estratégia para transformações nos contextos culturais no decorrer da história de muitos povos, com vistas à própria língua e ao desenvolvimento do conhecimento em várias áreas. Essa constatação é reafirmada ao se lembrar que os leitores são pessoas que "interagem, falam, argumentam, discutem o cotidiano" onde quer que estejam expostas, pois é, nesse contexto, que as representações são formadas, conforme Guareschi e Jovchelovitch (citação feita na Introdução, p.8).

Muito se tem estudado em virtude do interesse de um melhor entendimento da relação do homem em seus contextos sociais, isto é, a relação do homem com a sociedade. A 
Sociologia tem dado a sua grande contribuição, com estudos de célebres pensadores como Auguste Comte (1798-1857), David Émile Durkheim (1858-1917), Max Weber (1864-1920), Karl Marx (1818-1883) e outros. Porém, em síntese, serão destacadas as linhas de pensamento desses citados para ressaltar suas influências dentro do contexto de cada época e como referências para estudos posteriores.

Auguste Comte, francês, mentor do positivismo no século XIX, procurou uma forma de entender o mundo, o homem e as coisas. Na sua visão, tudo o que está relacionado ao saber humano, assim como os fenômenos sociais, é possível de ser organizado e sistematizado seguindo princípios adotados para as Ciências Exatas e Biológicas. Dessa maneira, haveria as possibilidades de se fazer manipulações e previsões e de tomar decisões de maneira a conduzir a sociedade a uma ordem social. Eliane Superti (2003) cita em seu artigo sobre o positivismo de Comte que,

\begin{abstract}
De acordo com o nosso autor, não eram as instituições, as relações materiais e estrutura hierárquica que constituíam o núcleo da sociedade humana, mas sim o conjunto de ideias, representações e crenças que formavam a maneira de pensar unanimemente partilhada por todos no grupo, ou seja, que engendrava o consenso, unindo os homens em uma dada ordem. E por ser assim, tanto a superação da crise como a reorganização da sociedade não podiam ocorrer com a limitação das ações sobre instituições, era preciso uma reforma intelectual que atingisse o modo de pensar, de representar a vida social (SUPERTI, 2003, p. 4).
\end{abstract}

A interpretação feita da citação é a seguinte: as mudanças na organização de uma sociedade não estariam, apenas, condicionadas a um movimento institucional para trabalhar elementos que possam gerar novos conhecimentos, mas também pela ampliação da visão de mundo dos indivíduos, de maneira a fazer fluir "o poder das ideias", para gerar uma nova forma de representar o seu contexto social.

Max Weber, alemão, que vivenciou um período em que as grandes cidades se encontravam em momento de mudanças significativas, como a Revolução Industrial, muito influenciado pelas obras de Karl Marx e Durkheim, procurou direcionar seus estudos para compreender as mudanças sociais que estavam ocorrendo e, dessa forma, construiu conceitos fundamentais para a sua teoria. De acordo com CAMPOS (2006, p.5), em sua Dissertação de Mestrado, de título Max Weber, o conhecimento sociológico da história: uma interlocução a filosofia helegiana, a Sociologia para Weber tem como base a ação social por estar mais ligada ao indivíduo pelo fato de se caracterizar como responsável pelo provimento de sentido à realidade, o que significa que o indivíduo conta com a liberdade para agir e modificar a sua realidade. 
Karl Marx, alemão, em sua teoria, conhecida como teoria marxista, apresenta o pensamento de que toda história humana parte da valorização do homem, o qual, como ser humano vivo, precisa alcançar as transformações necessárias para uma sociedade mais justa, igualitária e humana. O professor de Sociologia e Ciência Política, José Otacílio da Silva, em seu artigo A transformação social na visão da sociologia clássica, discorre que,

[...] para Marx, a transformação social consiste em um processo impulsionado pelas contradições que se estabelecem entre forças produtivas e relações de produção. No início do desenvolvimento do modo capitalista de produção, as relações de propriedade possibilitam o desenvolvimento das forças produtivas, mas, no decorrer do processo, as próprias relações de propriedade tornam-se um estorvo ao seu contínuo desenvolvimento. No bojo desse mesmo processo, desenvolvem-se as classes sociais com interesses antagônicos e que lutam entre si para conservar ou para transformar a sociedade existente. Conforme o desenrolar dessas lutas, ocorreria, então, a transformação ou a conservação da sociedade (SILVA, 2005, p.13).

Para Marx, então, as relações sociais são oriundas das relações de produção. Assim sendo, os valores sociais, culturais e religiosos, as normas que regem os indivíduos e as ideias políticas constituem o resultado dessas relações. As forças de produção tornam-se a base de sustentação do sistema capitalista. O capitalismo caracteriza-se pela divisão de classes, com relações antagônicas que conduzem à exploração e à desigualdade.

David Émile Durkheim, francês, devido ao seu papel importante para o desenvolvimento da Teoria das Representações Sociais de Serge Moscovici, será comentado com mais detalhes quando for abordada a questão que diferenciará representações coletivas de sociais, no capítulo 2, item 2.2, página 28, desta dissertação.

As sínteses das ideias desses pensadores têm a finalidade de destacar a visão de como o homem, como elemento social, no desempenho de seus papéis na sociedade, tem sido o mote de várias Ciências e, consequentemente, dando uma grande contribuição para os estudos da Sociologia e da Psicologia, possibilitando o surgimento de diversas teorias.

Comte, Weber e Marx abriram espaço para a concepção de que grandes mudanças podem ser geradas dentro de uma sociedade, quando são visados seus pontos estratégicos, tais como as crenças, os valores e as relações de produção. De acordo com interesses diversos, ideias com objetivos precisos podem ser manipuladas para a formação de novas representações, com base nas ideias ideológicas disseminadas pela interação dos indivíduos sociais, que circularão e se fortalecerão de forma a conduzir essa sociedade a uma unidade. As representações fortalecem-se pela troca dessas ideias nas interações sociais, via um consenso. 
Por não ser possível ignorar o movimento que ocorre com as novas descobertas científicas quando são socializadas, Moscovici enfatiza o papel constitutivo do social sobre a construção e a produção do saber. Como psicólogo social, ele defende a não separação dos fenômenos psíquicos dos sociais, de maneira que as Ciências Psicológicas e Sociais que os estudam possam manter uma relação muito próxima entre elas. Assim, acreditou ser necessário ficar muito atento à produção e ao pensamento dos sociólogos e dos antropólogos. Porém, um diálogo com outras áreas do conhecimento foi estabelecido durante o caminhar da teoria em estudo.

Arruda (2009), no que se refere a essa interação com outras áreas, conclui que

O fato de que a TRS seja uma teoria de interface - ou de aliança - entre a Psicologia, a Sociologia e a Antropologia, já indica que nela, como no pensamento moscoviciano de forma geral, não se trata de um encontro fortuito ou complementar de disciplinas, mas de áreas cujo íntimo parentesco é incontornável para entender a produção do conhecimento tal como Moscovici propõe: deslindar a construção do pensamento cotidiano pelos seus múltiplos autores, encontrar os processos que estão na base da mudança do pensamento e das práticas sociais (ARRUDA, 2009: p.739766).

Quanto aos estudos se cruzarem e, entre eles, circularem várias ideias e vários conceitos, na esfera das Ciências sociais, essas ações criam um movimento com diversas áreas do conhecimento que passa a estabelecer um entendimento de interdisciplinaridade em relação à Teoria das Representações Sociais - TRS.

\subsection{REPRESENTAÇÕES: DE COLETIVAS A SOCIAIS}

David Émile Durkheim, sociólogo, psicólogo social e filósofo francês, na virada do século XIX para o século XX, de acordo com Ribeiro (2014), procurou definir um método sociológico e o seu objeto de estudo com o propósito de estabelecer um status científico para a Sociologia, de maneira que se posicionasse no mesmo patamar das outras áreas do conhecimento, tratadas como ciência. Para Durkheim, os fatos sociais seriam apenas o objeto de estudo da Sociologia e, assim, os define como

Fato social é toda maneira de atuar, fixada ou não, suscetível de exercer sobre o indivíduo uma coerção exterior; ou ainda, que é geral na extensão de uma dada sociedade, conservando uma existência própria, independente de suas manifestações individuais (DURKHEIM, 2012: p. 40). 
Portanto, tudo o que determina constructo humano como formas de agir, de pensar e de sentir, pode ser considerado fatos sociais. Fatos sociais não brotam de um sentimento interno, mas externo, pois são estabelecidos na coletividade por meio do senso comum.

Em convívio social, os indivíduos, para se sentirem pertinentes aos contextos grupais, passam a agir de acordo com as ideias, com as normas que regem tais grupos. Por esse comportamento decorrente, pode-se afirmar que os fatos sociais se impõem aos indivíduos, exercendo certa coerção. Por isso, Benedict (2000, p.168) afirma que a grande maioria de todos os indivíduos que nascem em qualquer sociedade, adota, mesmo considerando as idiossincrasias existentes nas suas instituições, o comportamento ditado pela sociedade nas quais vivem.

Gerard Duveen (2013 apud MOSCOVICI 2013, p.13) afirma que, em seu esforço para estabelecer a Sociologia como ciência autônoma, Durkheim separou, de forma radical, as representações individuais das coletivas: as primeiras seriam objeto de estudo da Psicologia; e as segundas, da Sociologia. Citado como o principal mentor das Ciências Sociais moderna e pai da Sociologia, Durkheim trabalhava mais com as representações que denominou de representações coletivas e as suas influências na força social numa perspectiva estática das representações. Assim, Durkheim define-as:

\begin{abstract}
As Representações coletivas traduzem a maneira como o grupo se pensa nas suas relações com os objetos que o afetam. Para compreender como a sociedade se representa a si própria e ao mundo que a rodeia, precisamos considerar a natureza da sociedade e não a dos indivíduos. Os símbolos com que ela se pensa mudam de acordo com a sua natureza [...]. Se ela aceita certos modos de conduta, é porque entram em choque ou não com alguns de seus sentimentos fundamentais, sentimentos estes que pertencem à sua constituição (DURKHEIM,1978, p. 79).
\end{abstract}

Duveen (2013 apud MOSCOVICI 2003, p.14) complementa que a Sociologia de Durkheim está orientada àquilo que faz com que as sociedades se mantenham coesas, isto é, às forças e às estruturas que podem conservar ou preservar o todo contra qualquer fragmentação ou desintegração. Essas capacidades de integrar e de manter a sociedade são o que sacramenta as representações coletivas para Durkheim.

Farr (2002, p. 29) escreve que Durkheim produziu uma sociologia do conhecimento e não uma psicologia que se embasasse nas crenças generalizadas, tendo em vista que o conhecimento é público enquanto as crenças são pessoais, psicológicas e privadas. Assim, o termo chave "Representações" escolhido por ele foi para privilegiar uma dimensão do público/privado, num contraste entre o coletivo e o individual, colocando o foco sobre o público e ignorando o privado. 
Ao resgatar de Durkheim o conceito de representações como ponto de partida de reflexões para a sua Teoria das Representações Sociais, Serge Moscovici, romeno naturalizado francês, psicólogo social, procurou um entendimento da forma como os indivíduos em interação grupal, com atos e ideias ou imagens, conseguem organizar e transformar a sociedade. Oliveira (2004, 184), em seu artigo Representações sociais $e$ sociedades: a contribuição de Serge Moscovici, diz acreditar que,

não mais insistindo na diferença entre "coletivas" e "sociais", o autor quer mostrar que as idéias, embora cotidianas e sociovariáveis, podem também ser universais porque se perdem na nuit des temps das sociedades - elas pré-existem à vida; são um "ambiente" social e cultural, segundo Moscovici. Em consequência, têm certa "autonomia" e se descolam da estrutura social e material, o que faz o autor retornar à célebre fórmula durkheimiana.

Para Guareschi (apud GUARESCHI; JOVCHELOVITCH, 2013, p. 157), Moscovici tinha consciência de que o modelo de sociedade de Durkheim era estático e tradicional, pensado para tempos em que a mudança se processava lentamente. Dessa forma, é possível concluir que, ao pensar sobre o dinamismo da sociedade moderna, na maneira como se processa a formação das representações, caracterizada pelas mudanças rápidas, e no seu impacto nos grupos sociais, Moscovici deu-lhes a denominação de representações sociais. Assim, voltou sua pesquisa para os fenômenos mais dinâmicos e cotidianos, procurando reavaliar a exaltação do social sobre o indivíduo na busca de uma nova compreensão dos vínculos estabelecidos entre eles.

Moscovici (2003), quando se refere a Representações, afirma que

[...] são entidades sociais, com vida própria que se comunicam entre si se opõem umas às outras e se transformam, em harmonia, com o curso da vida, desaparecem somente para ressurgir sob novos aspectos, estando radicadas nas reuniões públicas, nos cafés, nas ruas, nos meios de comunicação, nas instituições sociais e, assim por diante. Este é o espaço em que elas se incubam, se cristalizam e são transmitidas (MOSCOVICI, 2003, p. 10).

Jovchelovitch (2000) ratifica a definição de Moscovici quando faz a afirmação que as representações sociais são formadas no encontro de atores sociais, nas várias mediações da vida pública, nos espaços em que sujeitos sociais se reúnem para falar e, assim, dar sentido ao cotidiano (JOVCHELOVITCH, 2000, p. 40).

Os indivíduos, em seus contextos sociais, estão em permanente processo de permuta de ideias, de percepções, de conhecimentos. O ser humano vive em sociedade e, pelo poder da 
comunicação, tem à sua disposição um meio de externar seus pensamentos, sua maneira de interpretar o mundo que o cerca, numa busca de parâmetros para se sentir e se fazer presente, e de encontrar uma forma de nortear o seu papel e suas ações entre os seus pares.

Solomon Asch (1952, p.142 apud Moscovici, 2003, p.40), quando faz referências às interações humanas, afirma que elas são acontecimentos e estão psicologicamente representadas em cada um dos participantes. As representações fazem-se presentes em todos os lugares, nos acontecimentos que interferem na rotina da vida dos indivíduos, com a capacidade de influenciar o comportamento de cada um, quando se encontram e se familiarizam entre si.

É muito importante o entendimento de que um indivíduo não cria uma representação porque se trata de uma tarefa inerente à força da coletividade na dinâmica da comunicação e da cooperação que ocorrem nos contextos sociais. As ideias, manifestadas no dinamismo destes, acabam gerando sentido e se estabelecem por meio de um senso comum. As ideias compartilhadas pelos membros de um mesmo grupo estabelecem, para o contexto grupal, uma leitura da realidade única, constituída de forma consensual, que proporciona aos seus membros um sentimento de pertencimento e segurança mesmo que essas ideias não sejam pensadas por eles. Elas são "re-pensadas, re-citadas e re-apresentadas", o que significa que

[...] a representação que temos de algo não está diretamente relacionada à nossa maneira de pensar e, contrariamente, por que nossa maneira de pensar e o que pensamos depende de tais representações, isto é, no fato de que nós temos, ou não temos dada representação. [...] elas são impostas sobre nós, transmitidas e são o produto de uma sequência completa de elaborações e mudanças que ocorrem no decurso do tempo e são o resultado de sucessivas gerações (MOSCOVICI, 2003, p. $37)$.

A partir do momento em que as representações criam corpo, elas adquirem, ao mesmo tempo, vida própria, e, assim, passam a circular no contexto social. Nesse movimento todo, encontram-se, atraem-se e repelem-se. Novas representações surgem e outras velhas morrem. Moscovici (2003 p. 41) ressalta essas características das representações. Por esse motivo, no estudo a ser feito sobre uma determinada representação, faz-se necessário investigar a sua origem, processo que pode ter como ponto de partida uma situação específica ou várias outras. De acordo com Martin Bauer (2013 apud GUARESCHI; JOVCHELOVITCH, 2013, p. 188), "uma representação particular pode, contudo, mudar de grupo hospedeiro e vagar por entre grupos sociais, assumindo vida própria”. 
As representações passam a exercer um papel fundamental para os indivíduos constituírem-se como integrantes em grupos sociais. Quanto menos consciências delas, maior tornam-se as suas influências. Ao se referir às representações, Denise Jodelet (2001), colega de Moscovici durante muito tempo, que fez um estudo sobre as representações sociais da loucura em uma aldeia francesa, também ressalta a sua importância na vida social ao afirmar que

\begin{abstract}
As representações sociais caracterizam-se como forma de conhecimento, socialmente elaborada e partilhada, com um objetivo prático, e que contribui para a construção de uma realidade comum a um conjunto social. Igualmente designada como saber de senso comum ou ainda saber ingênuo, natural, esta forma de conhecimento é diferenciada, entre outras, do conhecimento científico. Entretanto, é tida como um objeto de estudo tão legítimo quanto este devido à sua importância na vida social e à elucidação possibilitadora dos processos cognitivos e das interações sociais (JODELET, 2001, p.22).
\end{abstract}

Quando faz referência ao saber constituído pelo senso comum como um saber ingênuo, natural, diferenciando-o do conhecimento científico, Jodelet está-se referindo ao saber formado e expresso pela subjetividade dos indivíduos em suas relações cotidianas, que acaba dando a estes sentido à realidade. Quanto ao científico, formado por conhecimento validado por rigores lógicos, metodológicos e objetivos, ele tem a finalidade de estabelecer respostas prontas ao que não é familiar. As respostas são embasadas por esse conhecimento científico, independentes de vontade e de consciência pessoal, gerando reações imparciais e submissão às suas verdades. Esse fato se contrapõe ao que acontece em relação às representações as quais, conforme Moscovici (2003, p.52), "restauram a consciência coletiva e lhe dão forma, explicando os objetos e os acontecimentos de tal modo que eles se tornam acessíveis a qualquer um e coincidem com nossos interesses imediatos”.

Quando se pensa em senso comum, é necessário situar-se no dia a dia, na vida cotidiana, em que o pensar e a sua manifestação, por meio da linguagem, possibilitam a interação nos movimentos sociais. Os indivíduos sociais fazem parte de uma sociedade pensante, onde pensam por si mesmos, não recebem apenas informações, mas se condicionam a elas. Como indivíduos pensantes, inseridos na dinâmica das relações sociais, posicionam-se a respeito e até encontram soluções para as questões que se apresentam.

Para Moscovici (2003, p.96), o senso comum está continuamente sendo criado e recriado em nossas sociedades, especialmente onde o conhecimento científico e tecnológico está popularizado. Essa renovação dá-se pela evolução do conhecimento, pelo dinamismo das ideias e pelo movimento gerado pela comunicação no processo grupal. As questões são disseminadas pelas trocas, geram novas interpretações embasadas em novos conhecimentos e 
experiências, até que se estabelecem pelo senso comum e se tornam fatos que norteiam as ações e o comportamento dos indivíduos na sociedade.

Marková (2006) discorre que,

\begin{abstract}
Quando nascemos na sociedade e na cultura, nós nascemos também no conhecimento de senso comum. Ele está ao nosso redor e nós o adotamos - para o melhor ou para o pior. [...] Nós aprendemos estas coisas através da comunicação, através das atividades diárias e através das nossas próprias atividades. O conhecimento do senso comum está também entrelaçado com diversas formas de pensamento, de sabedoria e de comunicação. [...] (MARKOVÁ, 2006, p,196).
\end{abstract}

Para Marková, tanto a vida em sociedade como o uso da linguagem são governados por normas, de as quais o indivíduo se apropria, passa a fazer uso e a se comportar como é esperado pelo grupo. Essas normas são representações sociais constituídas de forma consensual e fortalecem-se e podem ser re-apresentadas em contextos socialmente compartilhados. Os primeiros conceitos e as primeiras normas de linguagem são adquiridos na infância, da linguagem falada no dia a dia, por meio desse compartilhamento.

\title{
2.2.1 O homem e a necessidade de comunicação
}

A capacidade que o homem possui como ser pensante e de comunicação, por meio da linguagem, o conduz ao compartilhamento de ideias na interação com o "outro", pois, como afirma Asch (1977, p. 109), “o fato é que as características orgânicas do homem exigem uma vida social, como condição ambiental natural”. Nesse compartilhamento, as ideias podem causar uma série de reações; algumas esperadas, outras inesperadas, que provocam e causam estranhamentos, geram conflitos e discussões. Porém, ideias comuns surgem após intensos embates, gerando nos grupos sociais acordos consensuais. Esse processo ocorre naturalmente em sociedades em que os indivíduos possuem a liberdade de expressão, em que o pensamento social segue o seu fluxo. Na ação e no pensamento, o homem sozinho não é mais completo; em sociedade, ele se torna um todo relativo (ASCH,1977, p.119). O homem, como ser social, no convívio e na troca relacional com o outro, estrutura-se, completa-se.

No estudo da obra de Asch sobre Psicologia Social, pode-se verificar que é nesse processo de interação social que ocorre a formação do eu, com capacidade de se avaliar, de exigir dos outros e de si mesmo. Para esse autor, a pressão de outros sobre nós coloca-nos na necessidade de lidarmos com tudo que se apresenta diferente, estranho, que mexe com nossas 
emoções, colaborando para a aquisição do controle delas e, assim, levando-nos a encontrar respostas novas.

Silva (2010, p.3), em seu artigo Representações Sociais, Ações e Sociedade Pensante: Interações e Perspectivas Possíveis em Educação Social, recorda registros históricos de sociedades nas quais, por ideologias e domínios de poder, o pensar diferente não poderia ser propagado sob o risco de severas punições. De certa forma, com base nesses fatos, fica comprovado o reconhecimento do poder dessa capacidade inata do homem como ser pensante, isto é, o poder das ideias. Silva, no mesmo artigo e página, afirma que "a história também registra que, embora reprimidas, censuradas, irracionais ou de domínio limitado, ideias defendidas por minorias dissidentes tiveram, irrefutavelmente, o poder de converter a maioria".

A diferenciação torna-se evidenciada entre os pares quando não existe essa possibilidade de troca em contextos nos quais os indivíduos não encontram espaços para a manifestação do seu pensar, para a troca e o processamento de novas ideias, pois ações decorrentes de um sistema dominante não reconhece o "outro" como integrante do grupo, mas como um estranho, um despersonalizado. Sem o reconhecimento do "outro" em sua diferenciação e singularidade, de forma que se possa estabelecer condições para que esse indivíduo faça-se presente, sinta-se inserido, é criado o espaço para a dominação do "eu" sobre o "outro" e, consequentemente, para uma anulação da alteridade. A palavra alteridade designa experiência com o "outro", colocar-se no lugar do "outro", perceber o "outro" em toda a sua plenitude, o que é essencial para o "conviver" e para o exercício pleno da comunicação. Na cultura ocidental, há alguns exemplos das consequências da priorização do "eu" em detrimento do "outro", na constituição de uma relação de poder. A leitura da obra de Bhabha (1998) possibilita ao leitor entender que, no discurso colonial, a alteridade é apresentada pela indeterminação do sujeito, um aparato de poder que depende da aceitação ou do repúdio dos colonizados em suas diferenças históricas, culturais e raciais.

Se não há acolhimento e compartilhamento gerados pela natural interação dos homens por meio da comunicação, também não há espaço para uma construção de mão dupla, uma percepção de si próprio que ocorre ao se perceber no outro, colocando-se no lugar do outro, não apenas procurando extrair do outro o que se espera, fazendo-se prevalecer verdades únicas. Uma estratégica marcante de regimes dominantes, totalitários.

A importância do reconhecimento do "outro" e seu acolhimento ficam evidentes na citação de Moreira e Vasquez (2007, p. 10), quando afirmam que o "eu” só realiza sua 
dimensão de sujeito quando se abre e hospeda o "outro". Essa hospedagem é, também, um ato de aceitação do que não é familiar.

Como os pensamentos são constituídos e transformados dentro de contextos sociais, nos quais os indivíduos interferem e são interferidos, Moscovici (2003: p.78) destaca que é dessa soma de experiências e memórias comuns que as imagens são extraídas, linguagem e gestos necessários para o homem superar o não familiar. Entretanto, não se trata de uma ação fácil, mas, para que isso ocorra, é preciso conhecer o processo de formação de representações, tendo em vista que a linguagem tem um papel muito importante, assim como o tem para a cultura de uma sociedade, pois, por meio da linguagem, o indivíduo adquire e apreende a cultura de seu grupo.

A relação entre linguagem e cultura está muito bem definida pelo que escreveu Bassnett:

No language can exist unless it is steeped in the context of culture; and no culture can exist which does not have at its center, the structure of natural language (BASSNETT, 1991, p.14).

Laraia (2009, p. 52), complementando o que afirma Bassnett no que se refere à linguagem e à cultura, expressa que "a linguagem humana é um produto da cultura, mas não existiria cultura se o homem não tivesse a possibilidade de desenvolver um sistema articulado de comunicação oral”.

\subsubsection{O não familiar}

Com base na teoria de Moscovici, quando o indivíduo se depara com uma pessoa, situação ou objeto que não se encaixam em suas representações, ele procura de imediato uma explicação. Primeiramente, ocorre a falta de reconhecimento e, em seguida, a ciência da falta de conhecimento. Isto é, a falta de identidade e a afirmação de não identidade. MacIver (1942, apud MOSCOVICI, 2003, p.81) afirma que "é a exceção, o desvio, a interferência, a anormalidade, que estimula nossa curiosidade e parece exigir uma explicação". Assim, movido pela busca de entendimento, o ser humano vai procurar uma familiarização com o que ainda não lhe é familiar, pois, no seu pensar, tudo tem uma causa, uma forma, um motivo, uma relação de causa e efeito, fins e meios. Entende-se que a procura de entendimento de uma determinada situação está sempre relacionada à procura de um motivo, pois se trata de ações geradas pela vontade de se entender o fato. 
Moscovici especifica dois tipos de casualidade: a primária, para a qual o indivíduo se volta espontaneamente, depende de finalidades. Ao tomar, por exemplo, um indivíduo que se depara com uma reação de uma pessoa que extrapola a normalidade, ele de imediato, passa a buscar uma explicação, pois tal situação foge de suas representações. Assim, para MacIver (1942, apud MOSCOVICI, 2003, p.81), muitas vezes, atribui-se a alguma "causa” específica todo o acontecimento que caracteriza uma situação nova, ou não prevista, ou mudada.

A casualidade secundária não é espontânea de acordo com a abordagem de Moscovici,

ditada pela nossa educação, nossa linguagem, nossa visão científica do
mundo e tudo isso que nos leva a desvestir as ações, as conversações e os
fenômenos do mundo exterior, de sua porção de intencionalidade e
responsabilidade considerá-los apenas como dados experimentais, que
devem ser vistos imparcialmente. (MOSCOVICI, 2003, p.82).

Um exemplo citado por Moscovici (2003, p.82) é bastante esclarecedor para o entendimento dessa casualidade como quando um indivíduo vê-se diante de um homem com vestimentas e atitudes tal qual um típico cidadão francês, imagem que, para o indivíduo, é caracterizada como familiar pelas suas representações. Porém, ao constatar que o homem não é francês, mas americano, ele não se adequa mais a esse modelo. Surge a suposição de tratarse de um comportamento singular, pois não confere com o tipo.

As duas casualidades, para Moscovici, são importantes, pois, nas representações sociais, as duas agem conjuntamente e, também, devido ao fato de as circunstâncias da existência social poderem ser manipuladas com o objetivo de destacar uma ou outra para fazer passar um fim, como um efeito. Ele afirma que "relações entre indivíduos, do mesmo que as relações entre partidos ou grupos políticos de todo tipo, fazem extenso uso desse procedimento, sempre que o comportamento de outras pessoas deve ser interpretado" (MOSCOVICI, 2003, p.83-84).

É fato o entendimento de o ser humano ter a necessidade de interagir com o meio para uma familiarização com o que se apresenta "estranho" diante de si. Em sua essência, traz consigo um medo entranhado de tudo aquilo que não lhe pareça familiar e, consequentemente, busca dar sentido a tudo que encontra ao seu redor, externando o que era apenas implícito. São possíveis entender, perceber e imaginar, com as leituras feitas sobre a história da humanidade, o que provavelmente ocorria quando indivíduos em grupos esbarravam com outros grupos à procura de novos horizontes para saciarem suas necessidades de sobrevivência e de ambição por constantes conquistas. É viável que, ao mesmo tempo em que 
se fortaleciam e se empoderavam com suas novas conquistas, eles tomavam consciência da existência de outros grupos de humanos com culturas e línguas diferentes.

Aqueles que não pertenciam ao grupo familiar eram estranhos, não familiares, estrangeiros, consequentemente, eram considerados sem possibilidade de comunicação, mudos. É difícil estabelecer a dimensão do quão assustador é para o falante de uma determinada língua, usada para estabelecer a comunicação entre membros de seu grupo, deparar-se diante de símbolos desconhecidos para representação de determinados objetos, ações ou quaisquer outras coisas. Um trecho destacado do livro intitulado The Conquest of America: The Question of the Other, de Tzvetan Todorov (1984) esclarece, exemplificando situações em momentos diferentes da história, essa reação espontânea do homem diante do "estranho", do "desconhecido", que é imaginá-lo inferior. Quando o indivíduo não fala a sua língua, ele é tido como mudo, bárbaro ou selvagem:

The first, spontaneous reaction with regard to the stranger is to imagine him as inferior, since he is different from us: this is not even a man, or if he is one, an inferior barbarian; if he does not speak our language, it is because he speaks none at all, cannot speak, as Columbus still bellieved. It is in this fashion that European Slaves call their German neighbors nemec, "mutes"; the Mayas of Yucatan call the Toltec invader nunob, "mutes"; and the Cakchiquel Mayas refer to the Mam Mayas as "stammerers" or "mutes". The Aztecs themselves call the people South of Vera Cruz nonowlca, "mutes" and those who do not speak Nahuatl they call tenime, "barbarians", or popoloca, "savages" (TODOROV 1984, p.76).

No pensar de Moscovici, as reações do indivíduo diante do que não lhe é familiar, tornando esse não familiar elemento invisível, irreal, ou com qualquer outra forma de leitura, justificam-se pelas limitações que ocorrem quando as fronteiras e as convenções desaparecem, quando as distinções entre o concreto e o abstrato tornam-se confusas, ou quando algo que o sujeito considerava inexistente, de repente, surge diante de si com toda a sua força existencial. São situações que o impedem de reagir como reagiria diante de circunstâncias que apresentam fatores familiares, causando uma sensação de incompletude e aleatoriedade. Diante disso, é possível entender como o homem citado no relato de Tzvetan Todorov, ao se deparar com o "estranho", com o "desconhecido", com pessoas como ele, mas, ao mesmo tempo, não como ele, as qualificava de formas diversas. Moscovici afirma a respeito:

O não familiar atrai e intriga as pessoas e comunidades enquanto, ao mesmo tempo, as alarma, as obriga a tornar explícitos os pressupostos implícitos que são básicos ao consenso. Essa "exatidão relativa" incomoda e ameaça, como no caso de um robô, que se comporta exatamente como uma criatura viva, embora não possua vida em si 
mesmo, repentinamente se torna um monstro Frankenstein, algo que ao mesmo tempo fascina e aterroriza (MOSCOVICI, 2003, p.56).

Hoje, diante de fatos inusitados que ocorrem no mundo, os indivíduos são surpreendidos por determinados acontecimentos que fogem aos padrões do que lhe é familiar, do consensual, gerando um fenômeno de pânico de multidões, representados por movimentos de fuga e mal-estar devido à perda de marcos referenciais, da ordem estabelecida. Portanto, uma forma de criar uma aproximação com o não familiar, com o que ameaça o nosso universo, é transferir o estranho do exterior para o interior, do longínquo para o mais próximo, pelo ato da re-apresentação, que ocorre pela separação de conceitos e percepções normalmente interligados e colocados em um contexto, onde o incomum torna-se comum, o desconhecido incluído em uma categoria conhecida, inserido em nosso mundo mental e físico. As leituras que são criadas dos acontecimentos, das imagens, dos objetos e das pessoas, antes não familiares, nem sempre são decorrentes de intenções conscientes, mas por meio de uma transferência para dentro de um universo de elementos que já são conhecidos, tornando-os, assim, confiáveis, normais e concretos.

Em sua Teoria das Representações Sociais, Moscovici discorre sobre as ações do homem diante do que é novo, do desconhecido, o elemento que o desestabiliza por não ser de seu conhecimento e que o coloca em situação de alerta na busca de uma representação. Tratase de um processo que acontece nos grupos, pois "representar significa, a uma vez e ao mesmo tempo, trazer presentes as coisas ausentes e apresentar coisas de tal modo que satisfaçam as condições de uma coerência argumentativa, de uma racionalidade e da integridade normativa do grupo" (MOSCOVICI, 2003, p.216). A importância de que esses elementos sejam elaborados de forma comunicativa é para que se fortaleçam em sentido, de maneira que os indivíduos e os grupos se orientem e adaptem a eles.

\subsection{PROCESSOS QUE GERAM REPRESENTAÇÕES: ANCORAGEM E OBJETIVAÇÃO}

A primeira reação que se opera no ser humano quando se depara com um elemento desconhecido, estranho para si, é buscar, no seu espaço mental, uma categoria em que possa encaixá-lo. Em seguida, procura dar-lhe um nome, um rótulo para colocá-lo numa esfera familiar, de forma que deixe de ser um elemento amedrontador e passe a ser reconhecido 
como familiar. Essa reação, conhecida dentro da teoria das Representações Sociais como ancoragem, é característica de um dos processos que geram representações.

Moscovici explica que ancorar é classificar e dar nome a alguma coisa, pois coisas que não são classificadas e que não possuem nome são estranhas, não existentes e, ao mesmo tempo, ameaçadoras (MOSCOVICI, 2003, p. 61). Quando o indivíduo não consegue avaliar, descrever para si ou para o outro qualquer elemento que se apresente diante de si, cria-se de imediato um distanciamento, uma resistência, até que consiga colocá-lo em uma categoria, em um protótipo, para que se processe a familiarização.

Quando se categoriza alguém ou alguma coisa, isso significa escolher um dos paradigmas que estão arquivados na memória e fazer uma relação com ele, de forma positiva ou negativa. Quando se trata de alguém, não se pode afirmar que se conhece e compreende esse alguém. Na realidade, ocorre uma tentativa de reconhecimento para descobrir quem é e a que categoria ele pertence. Consequentemente, a necessidade de tornar esse alguém o mais familiar possível faz com que uma informação já estabelecida venha imediatamente à mente para a formação de uma imagem precisa desse alguém. Então, se faz uma classificação pela generalização ou particularização. "A característica se torna, como se realmente fosse, coextensiva a todos os membros dessa categoria. Quando positiva, nós registramos nossa aceitação; quando é negativa, nossa rejeição" (MOSCOVICI, 2003, p. 65).

Um dos recursos para colocar um navio em segurança é lançar um ferro ao mar para que ele não fique à deriva. Para essa ação, diz-se "ancorar o navio", isto é, lançar âncoras ao mar. O termo "ancorar", usado no processo de geração de representação, não foge à interpretação diante do que foi exposto sobre ancoragem em relação a tornar familiar o que se apresenta "estranho". Para se ter uma melhor percepção desse processo, é mais fácil considerar como se o indivíduo encontrasse uma forma de sair do estranhamento, prendendose a uma ideia categorizada para se sentir seguro, ancorado diante do que até então era ameaçador, desconhecido.

Outra característica interessante na formação de uma representação é transformar algo ou alguém complexo em elemento concreto, tira-lo da mente e trazê-lo para o mundo real. Chamon (2006, p. 24), em seu artigo Representação Social da pesquisa pelos doutorandos em ciências exatas, escreve que "o mundo se modifica mais depressa do que a ideia que fazemos dele. Ao transformar o complexo em simples (objetivação) e o estranho em familiar (ancoragem), essa ação transformadora permite uma integração "suave" do novo e do 
desconhecido". Quando Chamon (2006) fala de objetivação, está-se referindo ao que Moscovici diz ser um processo muito mais atuante que a ancoragem.

Objetivar é materializar a ideia, é transformar a representação em realidade, encher o que está naturalmente vazio em substância. Um bom exemplo para o entendimento desse processo é apresentado pelo próprio Moscovici quando cita Deus, que parte de algo inacessível e invisível e passa a ser comparado a um pai. Em nossa mente, trata-se de uma pessoa com quem podemos contar e em quem podemos confiar. Materializar algo abstrato é resultado do pensamento e da fala. O pensamento gera ideias, e estas são externadas pela fala no processo interativo da comunicação, as quais em sociedade vão transformando e redefinindo conceitos e imagens por meio das experiências e das memórias desse compartilhamento e do tornar "as coisas conhecidas a partir do que já é conhecido". Moscovici afirma que

\begin{abstract}
As experiências e memórias não são nem inertes, nem mortas. Elas são dinâmicas e imortais. Ancoragem e objetivação são, pois, maneiras de lidar com a memória. A primeira mantém a memória em movimento e a memória é dirigida para dentro, está sempre colocando e tirando objetos, pessoas e acontecimentos, que ela classifica de acordo com um tipo e os rotula com um nome. A segunda, sendo mais ou menos direcionada para fora (para outros), tira daí conceitos e imagens para juntá-los e reproduzi-los no mundo exterior, para fazer as coisas conhecidas a partir do que já é conhecido (MOSCOVICI, 2003, p. 78)
\end{abstract}

Por unir a ideia de não familiaridade com a de realidade, a objetivação aparece para o indivíduo de forma acessível. Dessa maneira, tornam-se compreensíveis certas estratégias utilizadas por governantes e por outros ditadores com o objetivo de submeter suas ideologias às massas, utilizando-se das representações existentes para dar-lhes "corpo", torná-las reais.

Realmente, não é uma tarefa fácil quando se sabe que as representações são formadas em um mundo consensual. E nos estudos de Moscovici (2003, p.60), ele faz referência a um filósofo francês chamado Bachelard, que observou que o mundo no qual vivemos não é igual ao mundo dos pensamentos. O mundo que nós vivemos, esse mundo reificado, é constantemente modificado pelo avanço das ciências, das informações e dos acontecimentos, e as mudanças que ocorrem precisam ser assimiladas de uma forma mais simplificada e, com essa finalidade, são conduzidas a um mundo consensual, no qual serão "re-pensadas", "recitadas" e "re-apresentadas", e, como já foi explicado quando se falou do não familiar, onde o incomum se torna comum, o desconhecido é incluído em uma categoria conhecida, inserido em nosso mundo do pensamento e do mundo concreto, físico. 
Questionamentos surgem quando se pensa no fato de os homens serem tão diferentes e imprevisíveis e, mesmo assim, ainda conseguirem conviver numa certa estabilidade social. Essa ordem que ocorre nos contextos sociais está pautada pelo consenso dos grupos. Como os indivíduos em seus grupos buscam explicações diante de situações novas, nem sempre a imagem que criam, o comportamento que assumem e tudo o que expressam nos grupos sociais podem caracterizar, inevitavelmente, o mesmo procedimento que teriam fora deles. Dentro de seus contextos, os indivíduos precisam-se sentir inseridos, aceitos, seguros. Duveen (2013), quando se refere a essa questão de os indivíduos sentirem-se inseridos, escreve que Moscovici justifica tal fato quando fala de as representações sociais estabelecerem uma ordem que permite aos sujeitos se orientarem no seu mundo material e social, e comandarem-no. Duveen (2013) afirma que

Representações são sempre construtivas: elas constituem o mundo tal como ele é conhecido e as identidades que elas sustentam garantem ao sujeito um lugar nesse mundo. Assim, ao serem internalizadas, as representações passam a expressar a relação do sujeito com o mundo que ele conhece e, ao mesmo tempo, elas o situam nesse mundo (DUVEEN, 2013, apud GUARESCHI E JOVCHELOVITCH, 2013, p. $-215)$.

As representações dão aos sujeitos a segurança para que um lugar seja encontrado, no qual se sintam confortáveis para acompanhar o dinamismo das mudanças sociais, o que significa um lugar próprio no mundo. Importante é o entendimento de que as representações não são representações de pessoas, mas representações de grupos sobre um objeto, e, também, não são definitivas, porque se transformam de acordo com as mudanças que ocorrem na realidade em que se apresenta. Moscovici ressalta esse fato, quando afirma que

As representações individuais ou sociais fazem com que o mundo seja o que pensamos que ele é ou deve ser. Mostram-nos que, a todo instante, alguma coisa ausente se lhe adiciona e alguma coisa presente se modifica (MOSCOVICI, 1978, p.59).

\subsection{A RELAÇÃO CULTURA, REPRESENTAÇÕES E IDEOLOGIA}

A cultura influencia o comportamento social e diversifica, enormemente, a humanidade (LARAIA, 2009: p. 8). E o que caracterizar como elementos que constituem a cultura de um povo? Crenças, pensamentos, hábitos, vestimenta, alimentação, arte, música, suas representações e muitos outros tópicos que poderiam identificar um determinado povo e 
seu lugar de origem. Laraia (2009, p.63), quando afirma que "uma compreensão exata do conceito de cultura significa a compreensão da própria natureza humana, tema perene da incansável reflexão humana", infere que uma definição para cultura dificilmente será precisa pelo fato de sermos seres pensantes, reflexivos e interativos, influenciando e sendo influenciados pelas mudanças recorrentes da própria dinâmica do sistema cultural, e que, de uma geração para outra, podem ser identificadas grandes mudanças. Portanto, para uma melhor compreensão desse seu sentido abordado no desenvolvimento deste trabalho, o termo "cultura" será relacionado como fator de grande influência no comportamento dos indivíduos em seus grupos sociais, com capacidade de caracterizar um grupo em suas particularidades, identificando-o entre tantos outros.

A cultura existe pela ação da interação dos indivíduos e é muito importante entender o contexto em que ocorrem essas interações, pois, de acordo com Cuche (1999: p. 106/107), cada contexto impõe regras e convenções. Compreende-se que essas regras e convenções são pertinentes a todas as culturas, firmadas pelos grupos e pelas instituições, as quais se tornam norteadoras das ações e comportamentos dos indivíduos na busca de sua identidade e socialização.

Assim como para o termo "cultura", há também conceitos diferenciados para ideologia, que variam de acordo com o foco de abordagem. Será utilizada, para compreensão do elo estabelecido entre cultura, representação e ideologia, no desenvolvimento do tema desta dissertação, uma abordagem sobre ideologia tomando como parâmetros o estudo feito por Maria Luiza Tucci Carneiro, em sua tese de doutoramento, na Universidade de São Paulo, apresentada em abril de 1987, sobre O Anti-Semitismo na Era Vargas (1930 - 1945), publicada em 1988 e em seus vários artigos publicados.

Alberto Dines, no prefácio dessa obra, afirma que tudo o que foi publicado nessa época, nos jornais e nas revistas, como charges e artigos que apresentavam uma mensagem ou imagem racista, não era ditado pelo órgão estatal de censura DIP. Então, conclui-se que os responsáveis por esses trabalhos apresentavam seus pensamentos racistas por meio da imprensa como meio de formação de uma ideologia. Justifica-se tal ação ser decorrente do último modismo ideológico importado da Alemanha e Itália. Carneiro (1987, p. 51) discorre como "os nazistas transformaram o racismo num de seus mais fortes aliados" e relata que o antissemitismo não é invenção que deve ser atribuída a Adolf Hitler, pois as ideias e os conceitos que embasam essa ideologia são de origem medieval. Porém, Hitler soube, de forma estratégica, explorá-lo para a conquista de mais simpatizantes, tendo em vista que as ideias 
racistas encontravam-se em processo de "hibernação" na sociedade desde o período medieval. $\mathrm{Na}$ Alemanha, a ideia de antissemitismo tomou uma proporção de maneira que, rapidamente, foi se espalhando por alguns países da Europa.

As representações adormecidas vão se fundamentando nos grupos sociais, criando força e gerando representações mais convincentes, principalmente em períodos difíceis para as sociedades, como entre guerras que colocam os indivíduos diante de situações não comuns, com perda de identidade social e assim, oportunamente, as representações defendidas por interesses diversos vão deixando suas influências na maneira de pensar de um povo. Interpretações e convicções geram conceitos e valores, os quais, dependendo de como as imagens vão sendo tratadas pelos contextos sociais e políticos existentes, podem-se constituir em formas ideológicas com capacidade de reger comportamentos e orientar escolhas. Souza Filho (2003, p.73) ressalta, em seu artigo Cultura, ideologia e representações, que "em qualquer sociedade em que se manifeste, a ideologia assegura a coesão social, regulando os vínculos que unem os indivíduos às normas e aos papéis que lhe são atribuídos”. Para estar em um grupo, ser parte dele, é uma questão de o indivíduo ter que assumir uma identidade e as regras que norteiam suas ações e o seu comportamento. Souza Filho (2003) ainda destaca que

\footnotetext{
A força da representação advém do fato de que ela é capaz de incluir como fazendo parte da realidade a representação que dela se faz. Isto é, a representação é capaz de produzir imagens, conceitos, ideias etc. de modo a fazer com que, no pensamento dos sujeitos, torne-se possível passar da representação da realidade para a realidade da representação como sendo a própria realidade (SOUZA FILHO, 2003, p. 79).
}

Esta afirmação destaca uma realidade criada quando há um ancoramento do que não é familiar pelos paradigmas já existentes e arquivados, preenchendo o que antes estava vazio com um corpo novo, uma imagem, uma matéria, por meio do processo da objetivação, no qual uma representação manifesta-se e é externada por meio da comunicação. Nesse processo, o que foi objetivado passa a representar a própria realidade e, com ele, o indivíduo norteia todo o seu ser social no mundo em que se encontra.

A igreja, em sua ideologia pautada em valores religiosos e morais, ao se manifestar a respeito da civilização judaica como responsável pela morte de Cristo, como também por outras ideias difamantes que definiam os judeus como praticantes da usura, atribuindo o sucesso dos que sobressaiam em várias áreas à ação do diabo, foi de grande influência para a representação dos judeus como sendo de uma raça inferior. Porém, dentro do contexto histórico, a concepção do termo "antissemitismo" foi-se modificando, apoiado nas 
"pseudoteorias científicas", antropológicas e etnológicas, emergentes no século XIX, como destaca Carneiro (1987, p. 41). De qualquer forma, mesmo com as diversas interpretações ocorridas em relação ao conceito do termo, para essa autora, o povo judeu sempre foi apresentado como um indivíduo hostil à civilização, explorador dos mais fracos, desrespeitador da fé cristã, imoral, antissocial, depredador e de espírito revolucionário: uma anomalia social e racial. Porém, em relação ao ponto de vista econômico, era visto como um povo bem-sucedido. Talvez uma apreciação não considerada como uma qualidade pelas ideias correntes de ser um povo que chegava ao enriquecimento pela "exploração dos mais fracos".

Diante da alimentação dessas representações racistas e discriminatórias durante décadas, presentes na cultura de países com regimes ditatoriais, e seu fortalecimento por meio da adoção de uma ideologia racista, favorecida pelo Movimento Nacional-Socialista iniciado pelo próprio Hitler, em 1925, não foi difícil fazer despertar no povo alemão o ideal nacionalista. Em 1933, ao assumir como chanceler do Reich, Hitler e seus aliados, em nome de uma nova Alemanha e de um novo homem alemão, não tiveram dificuldade em manipular a massa por meio de um trabalho ostensivo de divulgação da positividade de sua imagem e de sua ideologia por meio de fotos, de panfletos e de pronunciamentos na rádio. Imbuído da ideia de fazer emergir uma raça pura, superior, invencível, dominante e um Estado divinizado, o Reich "armou-se de elementos de efeitos psicológicos, interferindo no comportamento do povo alemão" (Carneiro,1987, p. 67/68).

Como as artes de um modo geral têm um papel importante na formação cultural de um povo, a literatura foi alvo de uma ação reacionária e, assim, em nome da revolução cultural, obras consideradas "heréticas", de inspiração "não-alemã", foram queimadas para a "ressurreição de uma nova Era". Para um entendimento dessas ações extremistas, devemos considerar uma referência feita na Introdução desta dissertação sobre o posicionamento de Rodrigues (2000, p. 9-10) quando se refere à cultura "não como fonte das representações, mas seu efeito" e ao tradutor, considerando-se a importância de seu ofício, ao afirmar que "o tradutor constrói uma interpretação que vai ser movimento e desdobrar-se em outras interpretações". Levamos em conta que a ação de destruição de obras consideradas "inadequadas" a qualquer proposta ideológica, seja como a que ocorreu na Alemanha ou durante o Estado Novo no Brasil, foi por entender que o leitor, assim como o tradutor, constrói a sua interpretação de acordo com a sua visão de mundo. Por conseguinte, obras literárias tornam-se instrumentos facilitadores de geração de ideias que irão circular nos grupos sociais e fazer resultar novas interpretações, positivas ou negativas, que constituem um 
risco de gerarem novas representações desde que firmadas em um processo consensual. Qualquer situação que prejudicasse os ideais ideológicos, com efeitos na formação cultural do povo alemão no regime de Hitler ou do povo brasileiro no estadonovista, deveria ser radicalmente eliminada.

No decorrer desta dissertação, foi destacado que a cultura estabelece para os indivíduos um conjunto de normas, de costumes, de modelos de comportamento, de características linguísticas específicas, de instituições e de outras particularidades que constituem convenções. Essas convenções regem as ações dos indivíduos dentro de seus contextos grupais, mas, por terem sido convencionadas por meio do senso comum, perdem a concepção de serem arbitrárias, adquirindo-se um caráter de normalidade/naturalidade. Souza Filho (2003) afirma que, nesse estágio, a oportunidade estabelece-se para a ideologia ser ancorada e materializada. Acrescenta que

\begin{abstract}
a ideologia se sustenta justamente nesse desconhecimento. Um desconhecimento que é fonte da produção de representações que autonomizam como natural, única, inevitável, universal, sagrada, eterna e imutável a ordem instituída. Esse desconhecimento e essa autonomização do instituído caracterizam a situação de alienação e de sujeição vividas pelos sujeitos humanos na própria experiência da cultura, independente de modo de produção e de realidades sociais específicas (existência de classes, Estado etc.) (SOUZA FILHO, 2003,74).
\end{abstract}

Com base nas leituras feitas sobre Karl Marx, entende-se que a ideologia pode trazer uma série de consequências, assim como a alienação e o domínio da mente humana por meio de ações que levem ao convencimento, sem necessidade de que sejam recorridas àquelas que intimidam e agridem o indivíduo fisicamente, como as utilizadas em regimes ditatoriais e repressivos, por meio de torturas.

Um contexto ideológico marcante, como o regime nazista, pode gerar nas famílias, mesmo após décadas do fim da Segunda Guerra, comportamentos e posicionamentos pautados nas ideias defendidas por essa ideologia. Porém, se questionados a respeito da justificativa de suas ideias, não saberiam responder, apenas diriam que desde sempre foi assim, que muitos dos seus também pensavam e agiam da mesma forma. Uma justificativa para esse fato é considerar que representações maturadas por crenças ideológicas, advindas de geração a geração, vão moldando os membros de uma família. Assim, como de forma instintiva, condicionada a uma tradição, o indivíduo simplesmente repete o seu legado. As representações, quando estabelecidas, exercem uma força coerciva sobre os indivíduos, tornando-se um recurso para se criar uma identidade e um sentimento de pertença social, no 
caso, familiar. É como imaginar uma árvore que precisa ter suas raízes bem fincadas para se sustentar e se manter firme como um componente de uma paisagem secular, que, apesar das intempéries ao seu redor, não exercem influências em seu status. Cultura, representações e ideologias se interligam nos contextos sociais.

A interligação nos contextos ocorre pela comunicação. Quando se pensa em comunicação é feita uma ligação com a linguagem e ao seu produto social, que é a língua. Essa associação desperta a questão da diversidade e da traduzibilidade, quando se pensa em tradução e nos seus desafios para o tradutor. Portanto, essas questões serão abordadas no próximo item.

\subsection{LÍNGUAS: DIVERSIDADE E TRADUZIBILIDADE}

Quando se fala de traduzibilidade e de diversidade das línguas, é sempre lembrado o mito de Babel, segundo o qual, por castigo divino, ocorre a ruptura de Deus com os homens, com a destruição da torre que estava sendo construída, destinada a fazer uma ligação da terra com o céu. Com isso, as línguas foram separadas, dando início à diversidade e à incompatibilidade entre elas.

A partir de então, a história que prevalece é a de que ocorreu uma confusão no processo de comunicação entre os povos e, diante de todo o tumulto gerado, houve uma dispersão desses povos para os mais diversos lugares. Para Ricoeur (2012, p. 34), a falta de comunicação não foi o problema maior, mas, sim, os outros elementos que eram contrastantes e que estavam relacionados à linguagem, como os signos usados que identificam a língua de um determinado grupo. Em seus estudos, esse autor reforça o fato de a ação comunicativa ser uma característica natural do ser humano. Portanto, mesmo se encontrando diante de uma diversidade linguística, o homem sempre foi capaz de aprender e de praticar outras línguas. Essa premissa é também comentada por Patrícia Lavelle, no prefácio da obra de Ricouer (2012, p.10 e 11) Sobre Tradução, quando reforça a indeterminação constitutiva da condição humana, que é a de se inventar e a de se fabricar linguística e culturalmente de diferentes maneiras.

Mesmo com essa habilidade desenvolvida, a questão traduzibilidade versus intraduzibilidade tem sido o foco das reflexões sobre tradução. Conforme Michael Alpert (2001 apud ROUTLEDGE ENCYCLOPEDIA OF TRANSLATION STUDIES, 2005, p. 
294), "translatability is mostly understood as the capacity for some kind of meaning to be transferred from one language to another without undergoing radical change" 3 . Porém, essa compreensão conduz a outra questão muito discutida no campo da tradução, que é a fidelidade versus traição quando se leva em consideração a letra ou o sentido.

Strasser (2013, p. 153), em seu artigo Sobre as ruinas de Babel - A construção da Tradução em Borges, ressalta que esse trauma de Babel repete-se em todo ato de traduzir enquanto tentativa de reunir as línguas, de refazer a consonância entre o mundo e a linguagem. A sensação de perda, de impotência, de falha é a sombra que acompanha toda tradução. Portanto, mesmo a tradução sendo uma atividade muito relevante nas trocas interlinguísticas e interculturais, é também resultado das necessidades do ser humano de conhecer, de experimentar e de interagir com o outro, pois não há como ignorar a existência desse sentimento de incompletude que se manifesta diante de uma tradução.

Com base nos estudos de Batalha e Pontes Junior (2007, p.27), o que ocorre em relação à tese da intraduzibilidade é pensar que cada língua representa uma visão de mundo particular e única, não possibilitando a passagem de uma para outra devido à falta de correspondência entre a lógica e a gramática das diversas línguas. Porém, com a capacidade latente que o homem tem de fazer acontecer a dinâmica da comunicação, sempre haverá uma saída para as barreiras impostas pela diversidade das línguas, mesmo se considerando as culturas específicas em que estejam constituídas.

Em tempos atuais, a tradução é um processo muito importante que apresenta o tradutor como um mediador entre culturas. Durdureanu (2011), em seu artigo Translation of cultural terms: possible or impossible?, informa que, de acordo com Pierre Bourdieu, num sentido mais abrangente, somos membros de uma comunidade de ideias e ações por meio da linguagem que falamos. Essa autora acrescenta, ainda, uma citação de Duranti (1997), na qual observa que

words carry in them a myriad of possibilities for connecting us to other human beings, other situations, events, acts, beliefs, feelings... The indexicality of language is thus part of the constitution of any act of speaking as an act of participation in a community of language users (Duranti 1997, 46, apud Durdureanu, 2011) ${ }^{4}$.

\footnotetext{
3 "traduzibilidade é principalmente entendida como a capacidade de algum tipo de significado ser transferido de uma língua para outra sem sofrer mudanças radicais" (tradução nossa).

4 "as palavras trazem nelas uma miríade de possibilidades para nos conectar a outros seres humanos, outras situações, acontecimentos, atos, crenças, sentimentos... A indexicalidade da linguagem é, portanto, parte da constituição de qualquer ato de fala como um ato de participação em uma comunidade de usuários de idiomas" (Tradução nossa).
} 
O homem está inserido num mundo globalizado, permeado por diversas teorias sobre a tradução e o processo tradutório; cabe, portanto, ao tradutor fazer a sua escolha para o procedimento de seu ofício no entendimento da importância dessa negociação entre o estranhamento e a familiarização, pois “toda língua, em sua relação com o mundo, já produz o imprevisível” (GLISSANT, 1996, apud BATALHA; PONTES JR., 2007, p.92). Talvez seja por isso que Milton (2010, p.93) afirma que "a tradução é tão atraente por causa da impossibilidade de jamais alcançar uma versão perfeita. Tais projetos impossíveis são típicos do ser humano".

No próximo capítulo, será abordada a tradução como produto em contexto ideológico, quando carrega em si propósitos direcionados à manipulação do leitor considerando-se as representações existentes e na perspectiva de se gerarem outras novas. Outro ponto a ser ressaltado é o que leva uma tradução a superar o original. 


\section{CAPÍTULO 3 - TRADUÇÃO EM CONTEXTO IDEOLÓGICO}

\subsection{TRADUÇÃO: UM PRODUTO VALIOSO}

No início do Capítulo 1, Cândido é citado por afirmar que "a literatura desenvolve a quota de humanidade na medida em que nos torna mais compreensivos e abertos para a natureza, a sociedade, o semelhante”. Trata-se de uma referência que permite entender como é significativo para os leitores terem acesso a originais e a traduções, de maneira a facilitar o contato com o estrangeiro, promovendo a interação com culturas diversas. Assim, horizontes são expandidos e novas ideias são geradas desde todas as transformações ocasionadas por esse canal de contato com outras literaturas.

A posição de Derrida e Paz (citação feita ainda no Capítulo 1) ao colocarem a tradução no centro da atividade humana, responsável pelo avanço das civilizações, traduz, literalmente, o sentido do "poder das ideias", abordado por Duveen (2003, apud MOSCOVICI, 2003, p. 8).

Moscovici (1990, p. 119) esclarece que se pode dar à palavra "potência" o sentido que mais for conveniente. Quanto à palavra “ideia", pode-se substituí-la por um termo que pareça mais exato, como ideologia, visão de mundo, mito, informação ou representação social. Ainda assim, permanecerá a intenção primeira, pois, se associando, os homens transformam alguma coisa mental em física. Essa linha de pensamento é que o conduziu a explorar a variação e a diversidade das ideias coletivas nos contextos sociais para desenvolver a sua teoria.

Silva (2010), em seu artigo Representações Sociais, Ações e Sociedade Pensante: Interações e Perspectivas Possíveis em Educação, também com base na citação de Moscovici, afirma que

\footnotetext{
uma ideia não é simplesmente um pensamento considerado comum; é, antes de tudo, uma ação em potencial, desencadeada e desencadeando-se ao longo de um elo que permite às aglomerações humanas constituírem-se em grupos sociais. É por meio do pensamento que as pessoas iniciam um processo de influência recíproca, entabulam relações e reafirmam ideias, desencadeando ações e modos de compreensão do mundo e da vida (SILVA, 2010, p. 4).
}

O contato com outras realidades conduz o homem a repensar seus valores éticos, sociais e ideológicos, levando-o a novos conceitos os quais poderão ser disseminados de formas interativa e comunicativa em suas relações sociais. "The limits of my language are the 
limits of my world"5 é uma frase de autoria do austríaco Ludwig Wittgenstein (1889-1951), um dos mais importantes filósofos do século XX, encontrada como título e subtítulo de diversos trabalhos, e pode ser apresentada como um exemplo para caracterizar o poder da comunicação.

A tradução "abre portas" para um mundo de culturas diversificadas e, nesse ofício, segundo Katan (1999 apud FAGUNDES, 2001, p. 37) “o significado não é construído pelo tradutor, mas interpretado conforme as crenças individuais e da comunidade específica da língua da tradução". Portanto, o tradutor é um mediador entre culturas.

Por ser capaz de produzir efeitos culturais e políticos, a tradução tem o enorme poder de construir representações de culturas estrangeiras. A tradução pode ser considerada uma ameaça à estabilidade de determinados sistemas que buscam conduzir a sociedade de acordo com o regime de controle de massa, quando o indivíduo/leitor, como ser pensante, passa a conhecer novas culturas, novos valores e novas ideologias, e, com a sua capacidade de ser pensante, gerar ideias que circularão nos contextos sociais. Na história da humanidade, essa preocupação com as influências externas que não coadunam com os interesses internos de um regime autoritário e controlador, e pode ser apontada por meio das queimas de obras consideradas inadequadas, desde a Idade Média até décadas recentes.

Blume e Peterle (2013, p.8) relembram algumas observações de Derrida quando este ressalta que "a tradução é fruto, mas também alimenta, renova e dá sobrevida ao texto traduzido" e explicam que os textos sobrepõem-se e formam um grande mosaico, no qual cada peça complementa a outra, possibilitando um caleidoscópio de leituras. Essas leituras diversas geram reflexões importantes nos contextos em que circulam as ideias. Essas autoras (2013, p. 13) ainda ressaltam que a tradução, dentro da perspectiva de uma reescrita, "percorre um caminho marcado por aspectos culturais e ideológicos, que podem ser, de alguma forma, identificados e recuperados no produto final por meio dos inúmeros traços, vestígios e rastros que permanecem na página".

Com toda a influência designada à tradução, o desempenho de seu papel no enriquecimento cultural e no desenvolvimento científico e tecnológico de muitos povos é fato de destaque nos estudos da tradução.

As circunstâncias especiais podem ser geradas de ações pensadas estrategicamente, quando essas ações visam a objetivos específicos, como se tem feito com o uso da tradução. Nesse espaço, é também onde ocorrem, por parte daqueles que vão patrocinar a tradução,

\footnotetext{
${ }^{5}$ Wittgenstein, L. The Blue and Brown Books. Oxford: Blackwell, 1958, p. 53. "Os limites da minha língua são os limites do meu mundo" (tradução nossa)
} 
algumas escolhas que trazem por trás certas intenções a serem alcançadas via literatura. Esse procedimento é conhecido como patronagem.

\subsection{TRADUÇÃO PARA A PROMOÇÃO DE MUDANÇAS NA SOCIEDADE}

Inegavelmente, a tradução tem enriquecido as línguas e as culturas desde os primórdios de sua história. No capítulo inicial, há um destaque feito às traduções de Horácio e Cícero, que foram essenciais para o enriquecimento da cultura romana, além de se tornarem parâmetros para gerações posteriores de tradutores. Porém, desde o final da Idade Média, tem sido estratégica para a formação das línguas e das literaturas nacionais de muitos países.

A França e a Inglaterra deram apoio às traduções de obras estrangeiras, imbuídas com uma forte ideia nacionalista para a formação e para o aprimoramento da língua oficial dos respectivos países. É importante lembrar que, para manter a supremacia linguística da língua francesa, D'Ablancourt já fazia traduções visando manter o "bom gosto" da erudição de sua época. Não há como deixar de citar a preocupação de Dolet, que também foi a de Chapman, em estabelecer formas para que a tradução exercesse o seu importante papel na formação da língua vernácula francesa.

No entanto, a língua alemã teve a sua estrutura iniciada por meio da tradução da Bíblia, feita por Lutero, que usava uma tática tradutória com os objetivos de alcançar o entendimento da palavra de Deus e, ao mesmo tempo, de proporcionar uma base social. Pelo alcance de seus propósitos, passou a ser referenciado com o "artesão" da língua alemã.

Já na Índia, no início do século XIX, dentro de um contexto missionário protestante, a tradução da Bíblia teve como objetivos fomentar a assimilação dos textos bíblicos para as culturas linguísticas do país e criar uma identidade protestante para seus convertidos, conforme consta no texto de Hephzibah Israel, traduzido por Gabriele Greggersen (apud BLUME; PETERLE, 2013, p. 223-224).

Martha P. Y. Cheung (2013, apud BLUME; PETERLE, 2013, p. 317-339) explana sobre a influência da tradução no final do período Qing da China, na segunda metade do século XIX, a qual contribuiu para promover mudanças significativas na sociedade, ao seguir uma agenda ativista que visava a modernização do país.

Como não citar o trabalho dos missionários Jesuítas no Brasil, na época da colonização, que usaram a tradução para levar uma nova visão de mundo e, assim, abrir espaço para mudanças radicais na cultura dos silvícolas? 
Dennys da Silva Reis publicou um artigo com o título Impactos da tradução escrita no Brasil, na Tradução em Revista (2015: p. 33-54), em que destaca as mudanças decorrentes das obras que passaram a ser traduzidas a partir da vinda da Família Real para o Brasil, no século XIX. Os livros eram importados e, em sua maioria, escritos em francês, língua que era de conhecimento de uma pequena elite da sociedade da época. A partir de então, ocorre a importação de costumes europeus, como o hábito de leitura e, em consequência, a formação de um público leitor. $\mathrm{O}$ fato de aumentar o número de leitores não significa que foi modificado também o índice da população não letrada, mas, apenas, o aumento de pessoas letradas que passaram a vivenciar a leitura como rotina.

No mesmo século, ocorreu um investimento em traduções técnico-científicas a partir do francês, inglês e do alemão, para o enriquecimento não apenas do conhecimento de assuntos militares, marítimos e médicos, mas de diversos campos das Ciências.

Reis (2015) ainda destaca que as traduções de grandes e importantes obras, feitas por muitos médicos tradutores, como a do naturalista alemão Von Martius, Das Naturell, die Krankheiten, das Arztt und die Heilmittel der Urbewohner Brasiliens (Natureza, doenças, Medicina e remédios dos índios brasileiros) e como o Código de Ethica Médica adoptado pela associação Médica Americana, contribuíram para a formação de profissionais médicos e da própria Medicina no Brasil.

Com a tradução de manuais e livros, a agricultura teve um grande impulso com o conhecimento de novas técnicas, importadas da experiência de diversos países, contribuindo para as pesquisas em andamento e para as mudanças necessárias no manuseio do campo de produção, inclusive no Brasil. Os registros feitos das experiências positivas e até mesmo das negativas em outras culturas são importantes no intercâmbio do conhecimento e, nesse contexto, a tradução tem um papel de fundamental importância. Lógico que toda essa propagação de novos saberes só se torna possível com o facilitado acesso dos leitores às traduções.

Com o mesmo efeito, a tradução ocorre nesse mundo globalizado ao agilizar a integração de novas tecnologias em várias áreas do conhecimento e ao promover novas descobertas e novas estratégias que favorecem o desenvolvimento de sociedades emergentes.

Exemplos não faltam para o entendimento da tradução como geradora de mudanças importantes em contextos diversos, assim como o fato de ser um produto que tem a possibilidade 
de levar aos leitores monolíngues que não teriam acesso à língua de partida o conhecimento da linguagem e da cultura de outra sociedade.

Lefevere (1998:91 apud MENDES, 2012, p.25) afirma que "o impacto social de uma tradução depende de suas estratégias discursivas e de sua recepção. Esses dois fatores figuram no processo de formação de identidade", isto é, quando a linha tradutória adotada pelo tradutor o conduz a uma tradução que irá alcançar o seu público leitor de tal forma que poderá alterar alguns conceitos e comportamentos, e, dessa forma, intervir na composição de um novo perfil de uma sociedade. Um exemplo desse impacto social foi observado com o sucesso da tradução em português das obras da autora britânica J. K. Rowling, realizada por Lia Wyler. Trata-se de uma literatura destinada a um público infanto-juvenil, mas que despertou o interesse de leitores de todas as idades com os sete volumes da série Harry Potter.

No Brasil, as influências observadas foram muitas, principalmente, no contexto social, desde o despertar de jovens para a leitura, bem como mudanças nos estilos de vestir, no uso de novos vocábulos e expressões entre os pares. Para Wyler, em entrevista concedida à Revista Época (2007), quando relata “imagino que no início foi intenção da autora desenvolver gradualmente o vocabulário dos seus leitores, os mais novos auxiliados pelos pais, os mais velhos, pela consulta aos dicionários informatizados", a tradutora reforça a compreensão de como os jovens ampliaram a sua bagagem lexical. Para Wyler, o português, por ser uma língua de extraordinária riqueza, possui palavras em quantidade para descrever cenários, acontecimentos e diálogos, mesmos com construções sofisticadas.

A Teoria das Representações Sociais, já explanada anteriormente, justifica a ocorrência desses acontecimentos decorrentes de traduções por meio da apreensão de circunstâncias que permitem gerar mudanças significativas na vida de indivíduos e em sua dimensão social.

Esse poder de gerar mudanças é o que faz da tradução um alvo de interesse de governantes, instituições religiosas e outras, que acreditam na força da disseminação de ideias, provocada pela interação dos leitores em seus contextos sociais. Diante dessa possibilidade, será abordado, no item a seguir, um período da história do Brasil, no qual o seu governante não hesitou em investir nessa estratégia. 


\subsection{TRADUÇÃO EM CONTEXTO IDEOLÓGICO - ERA VARGAS (1930-1945)}

Nas religiões, nas ciências, nas ideologias são encontradas representações que se formam ao longo dos acontecimentos e podem aparecer de formas diversificadas. O direcionamento deste estudo está voltado à busca de sentido para a formulação de hipóteses que possam nos conduzir a possíveis respostas aos questionamentos levantados sobre as estratégias que os tradutores abraçam diante de um mundo de estudo e de pesquisa das culturas envolvidas, em as quais se deparam com representações e ideologias, além de outros elementos que lhes são impostos nos processos tradutórios.

O estudo sobre ideologia e representações sociais, no que diz respeito ao uso da tradução como instrumento com capacidade de transformar a maneira de pensar de uma sociedade, está focado em um período em que o Brasil foi governado por Getúlio Dornelles Vargas. Ele assumiu pela primeira vez o governo provisório em 1930. Em 1934, foi eleito indiretamente presidente constitucional e criou a Constituição de 1934, dando início ao processo de democratização do País.

Getúlio Vargas firmou algumas conquistas importantes, inclusive a ampliação das representações das classes trabalhadoras em forma de sindicatos e a liberdade de expressão. Porém, essa abertura fez com que os sindicatos criassem força e se organizassem em termos de movimentos de cobranças sociais, levantando um temor ao governo Vargas.

Em 1935, com a justificativa de conter a ampliação de grupos simpatizantes com o comunismo (regime então consolidado na União Soviética), que começavam a se manifestar no País, declarou estado de sítio. Dois anos depois, fechou o Congresso, as Assembleias Legislativas e as Câmaras Municipais e instalou o Estado Novo, que permaneceu até 1948, com uma política de ditadura. Passou a perseguir todos os que eram considerados como "uma ameaça à paz nacional”.

A popularidade de Vargas com os trabalhadores não pode ser negada por estar relacionada a uma série de medidas tomadas que oficializavam a jornada de trabalho de 44 horas semanais, a criação da carteira de trabalho e a definição de um salário mínimo para o trabalhador, embora ressaltando, aqui, que a legislação atendia aos sindicatos ligados aos órgãos governamentais.

Era inegável que Vargas tinha se tornado um líder carismático, justificando o fato de ser reconhecido pelo povo como "o pai dos pobres". Mesmo assim, não podemos desconsiderar o grande investimento feito em seu governo na indústria de grande porte, 
abrindo frente de trabalho e incentivo para investimentos em novas indústrias, em educação e, principalmente, em editoras para edição de livros em território nacional.

Houve um movimento para melhorar o nível de letramento da população, a formação dos professores, com um investimento enorme para a publicação local de livros pedagógicos e de literatura, de revistas, de jornais, de traduções, de reedições de obras esgotadas, e criação de bibliotecas públicas.

No entanto, para justificar todo esse empenho, precisava aumentar o número de leitores e a saída inicial foi a criação do Instituto Nacional do Livro - INL pelo Decreto $\mathrm{n}^{\circ}$ 93, em 21 de dezembro de 1937, para dar andamento aos projetos, como organizar e publicar a Enciclopédia da Língua Nacional. Para Wyler (2003, p.109), a ação do INL “... abrangeria apenas traduções escolhidas e subsidiadas de 'obras raras e preciosas' que interessassem à cultura nacional, especialmente os relatos de viajantes estrangeiros nos séculos anteriores". Os outros tipos de tradução eram controlados pelo Serviço de Divulgação da Chefatura de Polícia para impedir certas publicações que fossem nocivas para os brasileiros.

O DIP - Departamento de Imprensa e Propaganda foi criado em 1939 e se encarregava da propaganda e da promoção de seu governo junto à população. Esse departamento foi responsável pela censura a órgãos de imprensa e a meios de comunicação. $\mathrm{O}$ DIP, sob a direção de Lourival Fontes, e o Ministério da Educação, dirigido por Gustavo Capanema, trabalhavam como complementares. Velloso $(1987$, p. 4) relata que o primeiro, por meio do controle das comunicações, orientava as manifestações da cultura popular, e o segundo voltava-se para a formação de uma cultura erudita.

Ao trazer para junto do governo os eruditos, os intelectuais, tais como Drummond de Andrade (chefe de gabinete), Lúcio Costa, Oscar Niemeyer, Cândido Portinari, Mário de Andrade, Vargas tinha noção da importância dessas pessoas na formação de opiniões, e, portanto, aquele era o momento de estabelecer um elo desse grupo com a sociedade pelo que eles representavam para o povo, por intermédio de suas produções ou falas. Os intelectuais eram também responsáveis pela justificação ideológica do regime, por meio de criação de livros, de cartilhas e de participação em conferências para justificarem a política do governo e fazer exaltações às realizações e à figura de Vargas. Porém, conforme o que relata Prado (2015, p.29), nem todos os eruditos que estavam a serviço do Governo sujeitavam-se ao cerceamento da liberdade intelectual e à ideologia do Estado. O governo parecia "tolerar" divergências ideológicas, desde que convenientes a seus propósitos. 
O Brasil encontrava-se em um período difícil, o desemprego em alta, conflitos no continente europeu, uma população com um número de analfabetos superior a $50 \%$, uma quantidade de informações que eram processadas dentro das limitações da compreensão de um percentual significativo de indivíduos, portanto o investimento em educação tornou-se fundamental no Governo Vargas com o propósito de não apenas melhorar o nível cultural, bem como preparar profissionais qualificados para atender à demanda existente.

Para aumentar o número de leitores, havia a necessidade de mais escolas, professores bem preparados para um trabalho de letramento eficiente, de maneira que diminuísse, também, o número de analfabetos. Para Wyler (2003, p.108) a educação deveria servir de duplo propósito, o de produzir mão-de-obra qualificada e o de difundir o ideário estadonovista.

Então, é possível deduzir que a contribuição dos intelectuais da época era uma maneira de estabelecer uma aproximação maior com a população por meio da influência de suas falas e obras. O trabalho dos tradutores no ambiente literário brasileiro não pode ser esquecido, pois, mesmo num contexto de muita censura, as traduções se multiplicavam.

A censura estabelecida para o controle das traduções e de edições das produções dos autores nacionais, no período em destaque, justificava-se com base em uma série de motivos criados pelo Poder vigente, pautado por um radicalismo ideológico. Por conseguinte, a liberdade de expressão deixou de ser respeitada. Muitos dos motivos alegados pelo responsável para avaliar o produto estavam pautados em critérios desvairados e em valores pessoais, com justificativas de que nada poderia ser divulgado para denegrir a imagem de Vargas e do regime.

Para entender a estratégia varguista, é preciso ter noção da importância a ser dada aos pensamentos que podem ser constituídos dentro dos grupos sociais, diante da capacidade humana de pensar, que pode levar o indivíduo a interferir dentro dos grupos e a ter o seu pensar também interferido pelo pensar do grupo nas experiências que são vivenciadas nesse contexto.

Moscovici (2003, p.78) explica que é dessa soma de experiências e de memórias comuns que são extraídas as imagens, linguagem e gestos necessários para superar o não familiar. Assim, ao pensar numa população de um país ainda muito instável, com um grande número de pessoas não letradas, com pouco acesso às informações, vivendo sob o temor de que o Brasil fosse tomado por ideais nazifascistas que pudessem interferir na vida do povo 
brasileiro, abre-se espaço para o reconhecimento do elemento de mudança "estranho" que estava inquietando a sociedade.

O consenso que fortalece as ideias e cria representações que passam a nortear todos que constituem uma sociedade apresenta-se poderoso no pensamento dos grupos em relação às notícias que eram divulgadas sobre o leste europeu, tendo, à frente de ações radicais, ditadores poderosos. Oportunamente, o novo regime estabelecido por Vargas passou a usar a expressão "perigo vermelho" para qualificar todos os que apresentavam ideias comunistas. Compreende-se que, ao se aproveitar da insegurança do povo e da instabilidade que era evidente naquele momento, o governo varguista, no que diz respeito aos intelectuais e à população, fez uso de uma estratégia de manipulação de ordem comunicativa quando investe num processo dialógico, seja por meio dos recursos dos meios de comunicação disponíveis, seja por meio de outras formas, na possibilidade de formação de um senso comum, com vistas à concepção de uma ideologia nacionalista ao colocar o Estado no papel de defensor, protetor da cultura, dos valores e bons costumes. A imagem e os feitos do Presidente eram divulgados de todas as formas possíveis e, dessa maneira, foi conseguindo, dentro de grupos sociais, um pensamento circundante de que os propósitos do novo Governo eram o bem da população e o progresso do País em todos os aspectos. Uma estratégia de marketing muito semelhante à utilizada por Hitler para alcançar seus propósitos ideológicos.

Em abordagem anterior, foi citado que o legado de Karl Marx tem sido de muita importância para os estudos sociológicos, o qual é lembrado por Bosi (1992, p.194) quando afirma que uma das posições do pensamento marxista está na concepção de que. nas práticas sociais e culturais, enraizadas no tempo e espaço, formam-se as ideologias e as expressões simbólicas em geral. Formada uma ideologia, existe, então, à disposição, um instrumento de persuasão que fará uso de certas motivações que possuem como intenção gerar, nos indivíduos, o sentimento de estar diante de necessidades gerais para o bem comum.

Dentro do contexto histórico, é importante destacar que a ideia de um resgate da nacionalidade, da preservação da cultura e da língua nacional já vem desde o início do século XX, quando a cultura europeia exercia uma grande influência no País. O movimento modernista deu força ao projeto de nacionalização, já que, nessa época, a literatura francesa predominava, assim como a língua portuguesa tinha como base a língua portuguesa de Portugal.

Quando o Governo Varguista entende que, para propagar a sua ideologia, precisa ter uma população mais letrada para poder aumentar o número de leitores, tem a percepção de 
que, com o controle do que seria colocado à disposição para o exercício intelectual, não desvirtuaria o pensar desses leitores, e, com o aumento do poder de consumo, ir-se-ia melhorar o mercado livreiro e, consequentemente, ter-se-ia uma sociedade mais preparada para apreender os objetivos de um governo que visava um Brasil progressista e com uma cultura nacionalista. O Estado procurava meios para se fazer compreendido e reconhecido pelo povo.

Mota (1979, p.87) relata que o Estado Novo inaugurou um tipo novo de relacionamento Estado/intelectualidade (...) por entender que os intelectuais tinham, por meio de sua visão de mundo, seus posicionamentos, seus manifestos, obras ou, no ofício como educadores, uma capacidade de comunicação, que poderia exercer considerável influência não apenas entre grupos dominantes e dirigentes, bem como em todas as classes da população. Diante do posicionamento de Mota, reconhecendo-se que muitos desses intelectuais são importantes nomes das mais diversas artes, cujos trabalhos e obras constituem-se referências na atualidade, o fato de terem prestado serviço a um governo de repressão causa um estranhamento e levanta uma série de questionamentos.

Em sua tese de doutoramento, Prado (2015, p.28) esclarece que

\begin{abstract}
A falta de profissionalização e da infraestrutura necessárias para produção literária rentável levava muitos escritores ao jornal como solução para o problema financeiro, o que muitas vezes podia representar o primeiro passo para a divulgação e venda das suas obras. Os escritores também buscavam no funcionalismo público a segurança financeira, paradoxalmente, assumindo posições dentro de um governo que condenavam.
\end{abstract}

Já naquele contexto, os tradutores eram muito mal remunerados, tanto que Érico Veríssimo adentrava nas madrugadas para reforçar o seu orçamento doméstico. Outro ponto que deve ser levado em consideração é o posicionamento de Miceli (1966, p.18) quando ele afirma que "não havia nenhuma possibilidade de se viabilizar uma carreira artística ou literária fora dos marcos institucionais dominantes". Dessa forma, justifica-se a explicação do que o homem é capaz diante da necessidade de sobrevivência num momento de restrições.

\title{
3.3.1 A tradução como instrumento de manifestação
}

A censura imposta pelo estadonovista, com base em Wyler (2003, 108-130), leva a uma série de restrições, inclusive à importação de publicações estrangeiras que pudessem ser 
prejudiciais aos valores nacionais e a prisões de escritores dissidentes cujas obras foram destruídas por ordem do Governo. Em decorrência, houve por parte dos editores uma mudança de estratégia, passando a investir em publicações técnicas, didáticas, infantis e traduções de ficção estrangeira. Assim, muitas editoras, ao mudarem o seu foco, criaram suas próprias equipes de tradutores, formadas por "astros das letras nacionais".

Wyler (2003, p.115) atesta que, mesmo com o aumento do número de tradutores no mercado, muitos não tinham a percepção de sua importância para tais editoras. Mas, dentre esses tradutores, encontravam-se os que viram a grande oportunidade de fazer uso desse instrumento para manifestar, com sutileza e muita habilidade, seus pensamentos e suas críticas, ou até fazer propaganda de seus partidos políticos. Um deles foi Monteiro Lobato.

Lobato, por seu perfil de um homem político, nacionalista, não admitia que o povo ficasse alheio aos problemas existentes no Brasil. Para que esse conhecimento fosse possível, usou o seu trabalho de escritor, editor e tradutor não só para emitir sua opinião a respeito de certas questões, como também das medidas tomadas pelo Governo, as quais, em sua percepção, não contribuíam para o desenvolvimento do país. Assim, em suas traduções, ao trazer a cultura estrangeira adaptada à realidade nacional, aproveitava para semear suas pontuações de maneira a germinar reflexões nos leitores brasileiros sobre a realidade brasileira. Óbvio que a censura não o perdoou.

Vasconcellos descreve Monteiro como

[...] alguém rebelde contra a estrutura oligárquica do poder vigente; nacionalista; cada vez mais preocupado com a miséria do povo e consciente de que a propriedade das elites dela dependia; adversário de ideias, crenças, valores - principalmente os da educação católica - que favorecessem a manutenção do status quo; vago defensor, em teoria, de ideias socializantes contra o obscurantismo autoritário do poder [...] (VASCONCELLOS, 1982, p.36-37).

O escritor Monteiro Lobato deu voz aos seus personagens para que estes questionassem e debatessem os problemas que eram destaques naquela época. Aqueles mesmos posicionamentos, hoje, na atual conjuntura econômica e social em que o Brasil se encontra, traduzem o mesmo sentimento da grande maioria do povo brasileiro.

Na adaptação que fez de Peter Pan, citada por Wyler (2003, 115), quando um de seus personagens diz que "há no Brasil uma peste chamada governo que vai botando imposto e selos em tudo...", é um exemplo de manifestação crítica ao regime político vigente no período da Era Vargas.

A criação de Emília, uma boneca de pano, pelo simples fato de não ser humana, lhe foi concedido o papel de ser uma personagem muito inteligente, irreverente, muitas vezes mal- 
educada, com a liberdade de falar o que bem entendesse. Lógico que a boneca Emília se tornou um interessante elemento para expor as alfinetadas de Monteiro contra o sistema vigente de Vargas. Certamente, Lobato não criaria uma personagem com essas características sem um objetivo preciso. Arapiraca (1986, p.486), em sua tese de doutoramento, afirma que "na hora em que Lobato traz Emília com essa inteligência, capaz de dominar o mundo, ele deixa ao leitor a pista para que perceba o risco da exploração que pode ser exercida através do conhecimento, imaginação e razão".

Campos (2009, p.79) afirma que o projeto tradutório de Lobato causou grande impacto cultural no Brasil por permitir que novos temas, personagens e ideologias estrangeiras perpassassem suas traduções, representando uma renovação do contex to literário nacional.

Lobato, com uma postura bem domesticante em seu processo tradutório, levava seu leitor a uma familiarização com os personagens e suas ações, usando vocabulário bem característico da cultura brasileira. Para ele, "a tradução tem que ser um transplante. O tradutor necessita compreender a obra e o autor, e reescrevê-la em português como quem ouve uma história e depois a conta com palavras suas" (LOBATO, 1964, p.128).

Quando as palavras carregam um pensar diferente e, de forma sutil ou direta, levantam questões que podem conduzir a reflexões sobre a vida, os valores morais, políticos e sociais, o indivíduo leitor pode ser instigado a pensar e, consequentemente, a ter e a compartilhar ideias, gerando um novo olhar e um novo pensar. Rodrigues (2000: p. 89-98) relata que, quando os signos entram em circulação, constituem um discurso, constroem significados que se disseminam e se entrecruzam e são, ao mesmo tempo, produto e produtores de ideologia. De acordo com a teoria de Moscovici, as palavras em comunicação na interação dos indivíduos, quando se firmam de forma consensual, geram novas representações e ideologias.

\subsection{AUTOR DE ORIGEM JUDAICA E SUA OBRA NO ESTADO NOVO}

Em pleno contexto do Estado Novo, para divergir da realidade na qual muitos eruditos e intelectuais brasileiros se encontravam a serviço do Estado, chega ao Brasil Stefan Zweig, austríaco, de origem judaica, escritor mais lido no mundo, autor de livros editados em várias línguas, tradutor do francês para o alemão. $\mathrm{O}$ autor, ao receber um convite para participar de um congresso em Buenos Aires, aceita um outro convite para visitar o Brasil, feito pelo Governo brasileiro. 
De sua experiência na inter-relação com o povo do litoral, do interior e dos mais diversos recantos, surge o seu encanto pela terra e pelo povo brasileiro. Desse seu encantamento, nasce um livro intitulado Brasilien ein land der zukunft, em 1941.

O fato de sua obra ter sido traduzida e publicada em várias línguas, simultaneamente ao lançamento do original, era uma grande oportunidade, na época, de colocar o País diante dos olhos do mundo, com possibilidades de despertar a atenção e os interesses externos que pudessem contribuir ao projeto de desenvolvimento estabelecido pelo Governo do Estado Novo.

Não há identificação, nos anais de sua história, que caracterize qualquer compromisso registrado com o governo estadonovista na ocasião da primeira visita de Stefan Zweig e, posteriormente, no seu retorno, quando trouxe consigo sua segunda esposa, com a decisão tomada de fixar residência em terras brasileiras, pois já tinha em mãos a conquista de sua cidadania.

Questionamentos podem ser levantados no que diz respeito a Stefan Zweig por não ter recebido qualquer intervenção de censura em relação ao seu livro e, principalmente, pelo motivo de seu visto de permanência não ter sido negado, apesar de sua origem judaica, pois havia uma determinação do Estado de não concessão de vistos aos estrangeiros de ascendência semítica.

Esse fato é bem polêmico ao se considerar que, no Governo de Getúlio, Olga Benário, judia e esposa de Carlos Prestes, militante do Partido Comunista, foi deportada pelo Governo brasileiro e entregue à Gestapo. Uma hipótese a ser levantada a respeito da passividade do Governo em relação a essas observações pode ser justificada pelos mesmos interesses em ter os intelectuais a serviço do Estado. Afinal, Stefan Zweig era reconhecido mundialmente e já contava com o carinho e a admiração de muitos brasileiros, ou seja, sua obra era importante para o objetivo nacionalista de Vargas. De acordo com a professora da USP Karen Macknow Lisboa (2014, p. 10), “certamente essa imagem elogiosa da sociedade brasileira veio ao encontro de anseios propagandistas do regime de Vargas no cenário internacional a despeito da crítica indireta de Zweig à política imigrantista restritiva".

Dessa forma, ao ser analisada a estratégia de Vargas em apostar nos meios de comunicação de massa, para estabelecer uma ideologia nacionalista, vale considerar uma reflexão sobre a afirmação de Moscovici (2003, p. 155):

levantar questões sobre os efeitos dos meios de comunicação de massa, sobre a influência exercida por uma fonte autoritária ou não, sobre a eficácia da mensagem anunciada no início e fim de uma fala, é confinar nossa disciplina dentro de limites 
puramente pragmáticos, colocados pelas exigências dos donos, ou dos manipuladores, dos meios de comunicação de massa.

Com base no posicionamento desse autor, não ficará difícil de acreditar que os autores/tradutores ou simplesmente tradutores desse período histórico, prestando serviço ao Estado, devem ter feito uso de estratégias tradutórias habilidosas para atender às exigências estabelecidas em relação ao produto, isto é, a tradução.

A tradução em português, do seu livro sobre o Brasil, com o título Brasil, país do futuro, foi feita por Odilon Gallotti, editada e publicada pela editora Guanabara, em 1941, quase que simultaneamente ao lançamento do original,

Odilon Gallotti foi um renomado médico psiquiatra, tradutor do alemão, que deu voz a Freud em língua portuguesa com a tradução de alguns de seus textos. Não foi encontrado, no decorrer deste estudo, citações que justificassem a sua escolha como tradutor da obra de Zweig. Porém, não são descartadas algumas hipóteses que surgiram no decorrer da pesquisa, como Odilon ser psiquiatra e tradutor de obras de Freud, este que foi mestre e amigo de Zweig. A respeito das novelas de Zweig, Dines (2012, p.35) afirma que "suas novelas vendem sucessivas edições graças aos toques psicológicos assimilados no convívio com Freud [...]”.

Uma tradução em português de uma obra sobre o Brasil, de um autor tão renomado e, ainda, com Odilon Gallotti responsável por esse processo tradutório, obviamente, traria uma repercussão favorável na divulgação da obra.

Uma surpresa ocorreu durante o andamento deste trabalho. Ao ser adquirido um exemplar dessa tradução em língua portuguesa, em um site de compra, foi observada a existência de uma dedicatória feita em seu prefácio, direcionada a uma pessoa de nome Odilon, conforme figura 1. Todavia, não foi cogitada qualquer outra possibilidade, que não fosse, apenas, um caso de homônimo, apesar das coincidências. 
Figura 1 - Edição brasileira - ano 1941. Dedicatória.

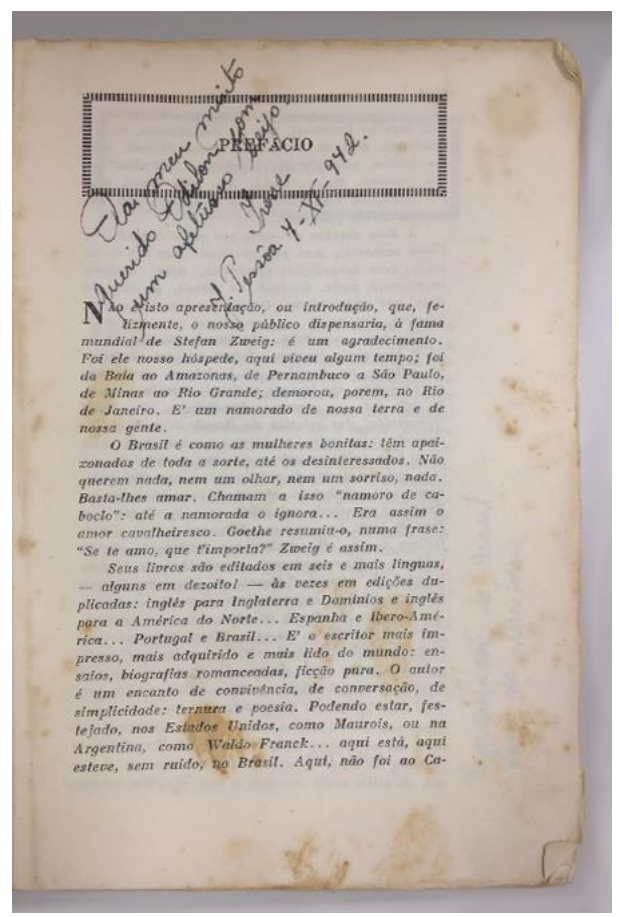

Fonte: foto e arte Diogo Saúde, 2017.

A edição da tradução em português, adquirida para o presente trabalho (figura 2) por se tratar de uma edição de 1941, é realmente um exemplar raro, por ser da primeira edição. A comprovação deu-se por comparação feita com a foto apresentada por Alberto Dines, em seu livro Stefan Zweig No País do Futuro (2009, p.154-155), conforme figura 3. 
Figura 2 - Edição brasileira - ano 1941
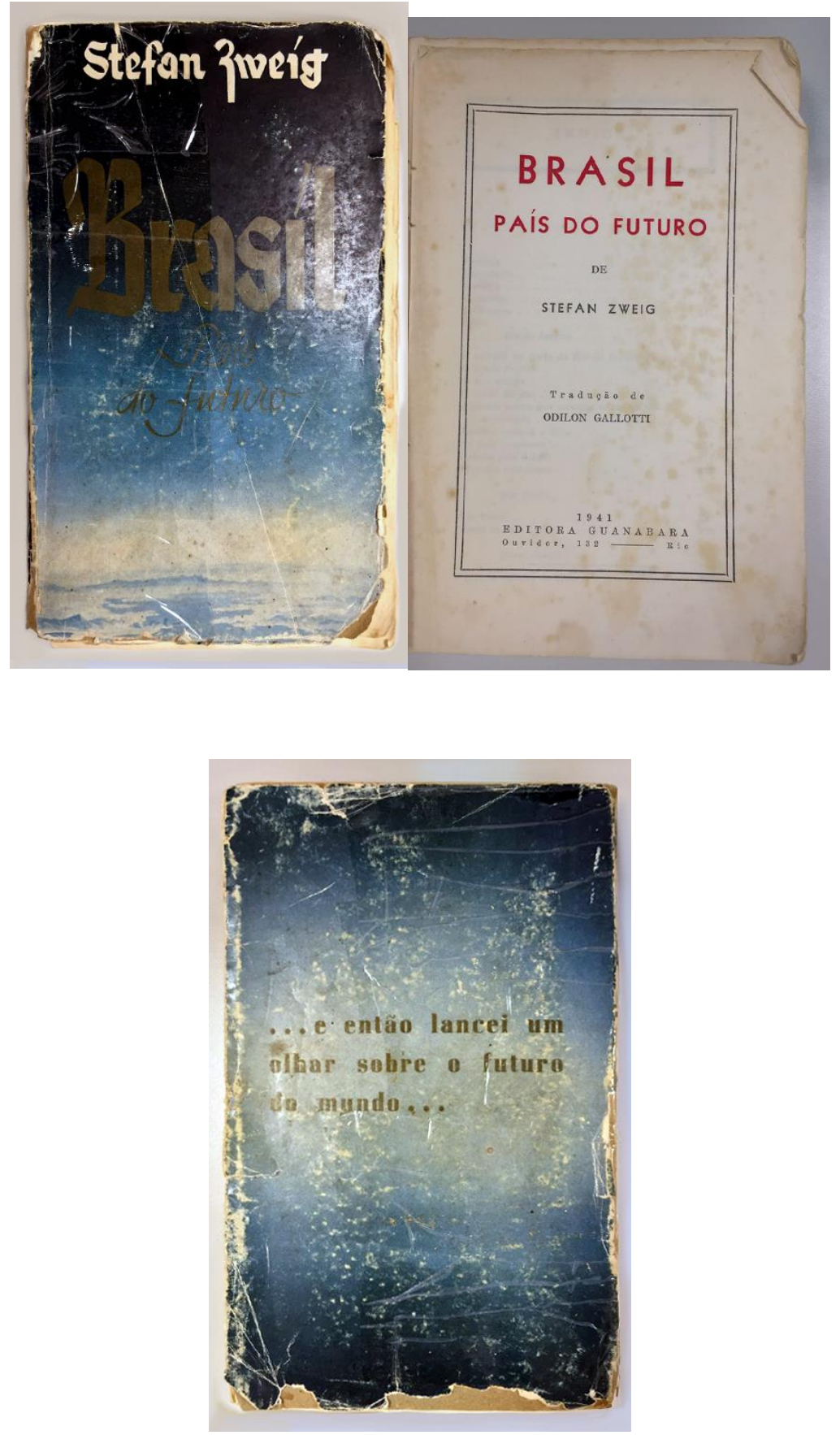

Fonte: foto e arte de Diogo Saúde, 2017. 


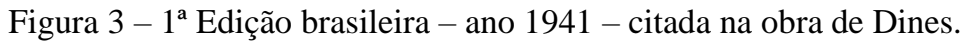

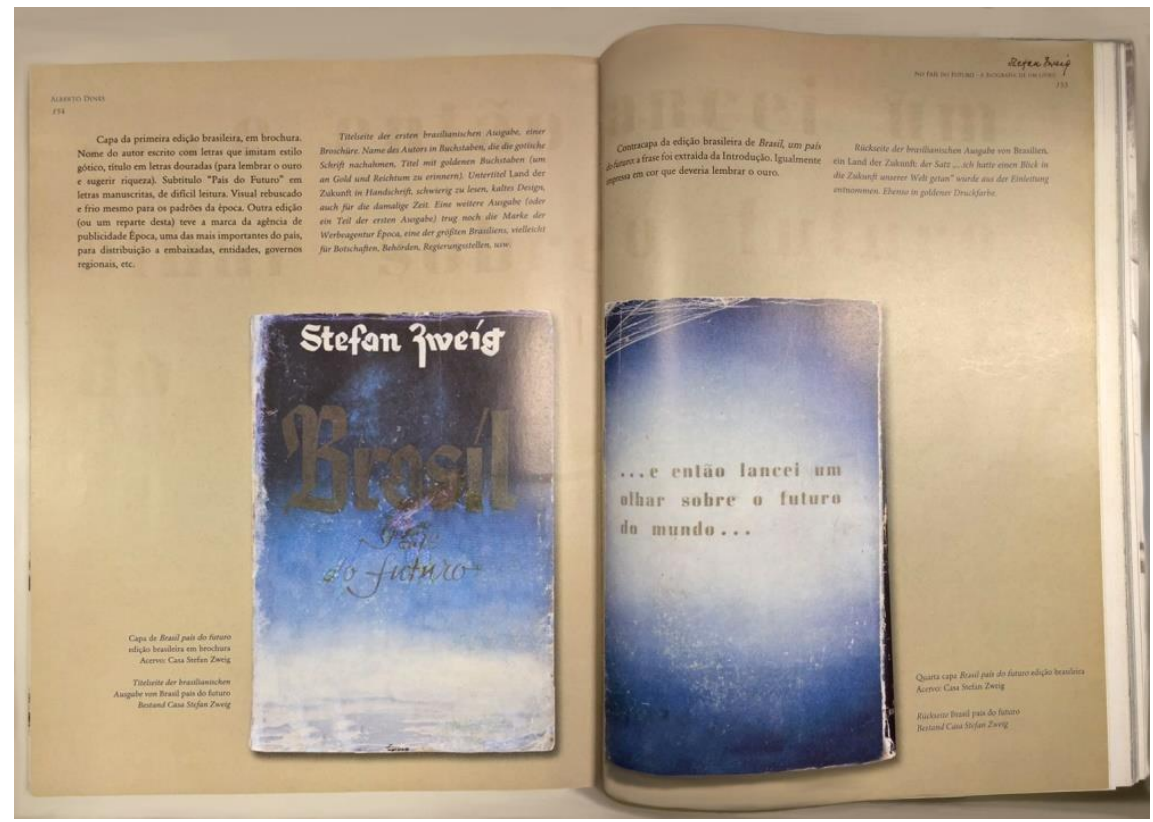

Fonte: foto e arte de Diogo Saúde, 2017.

Dines (2009, p.154) comenta que a capa dessa primeira edição brasileira de Brasil, país do futuro, em brochura, apresenta o nome do autor escrito com letras que imitam estilo gótico, título em letras douradas (para lembrar o ouro e sugerir riqueza), com o subtítulo País do Futuro.

em letras manuscritas, de final de leitura. Esse autor considera, ainda, que não houve uma preocupação de se fazer uma edição com uma capa mais requintada, pois, para os padrões da época, apresenta um "visual rebuscado e frio". Na contracapa dessa mesma edição, há a frase de Stefan Zweig (1941, p. 12), da introdução de sua obra “... e então lancei um olhar sobre o futuro do mundo...", em cor que também lembra o ouro.

A tradução em língua inglesa será utilizada neste trabalho para que seja feito um contraponto com a tradução em português, de onde serão destacados fragmentos que ilustrarão comentários específicos. Trata-se de um volume próprio de coleção, possivelmente das obras de Stefan Zweig, da Cassell and Company Ltd . A tradução foi feita por Andrew St. James, pseudônimo usado por James Stern, publicada na Grã-Bretanha, em 1942 (Figura 4). A edição americana foi impressa por The Viking Press - New York, em 1941, apresentando a tradução do próprio Andrew St. James. 
Figura 4 - Edição em língua inglesa - ano 1942 - publicada na Grã Bretanha.

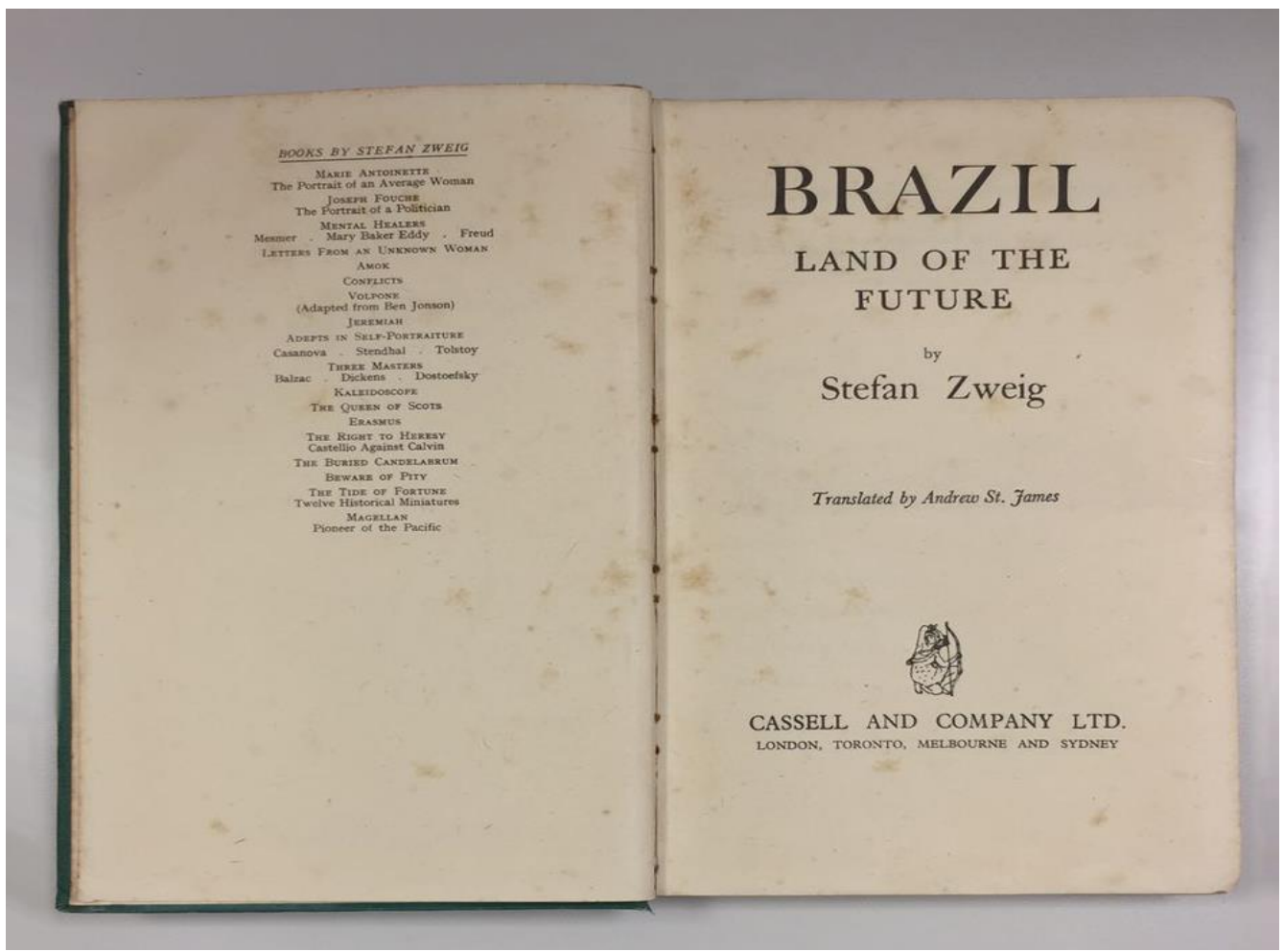

Fonte: foto e arte de Diogo Saúde, 2017.

Figura 5 - Índice da Edição em língua inglesa - ano 1942

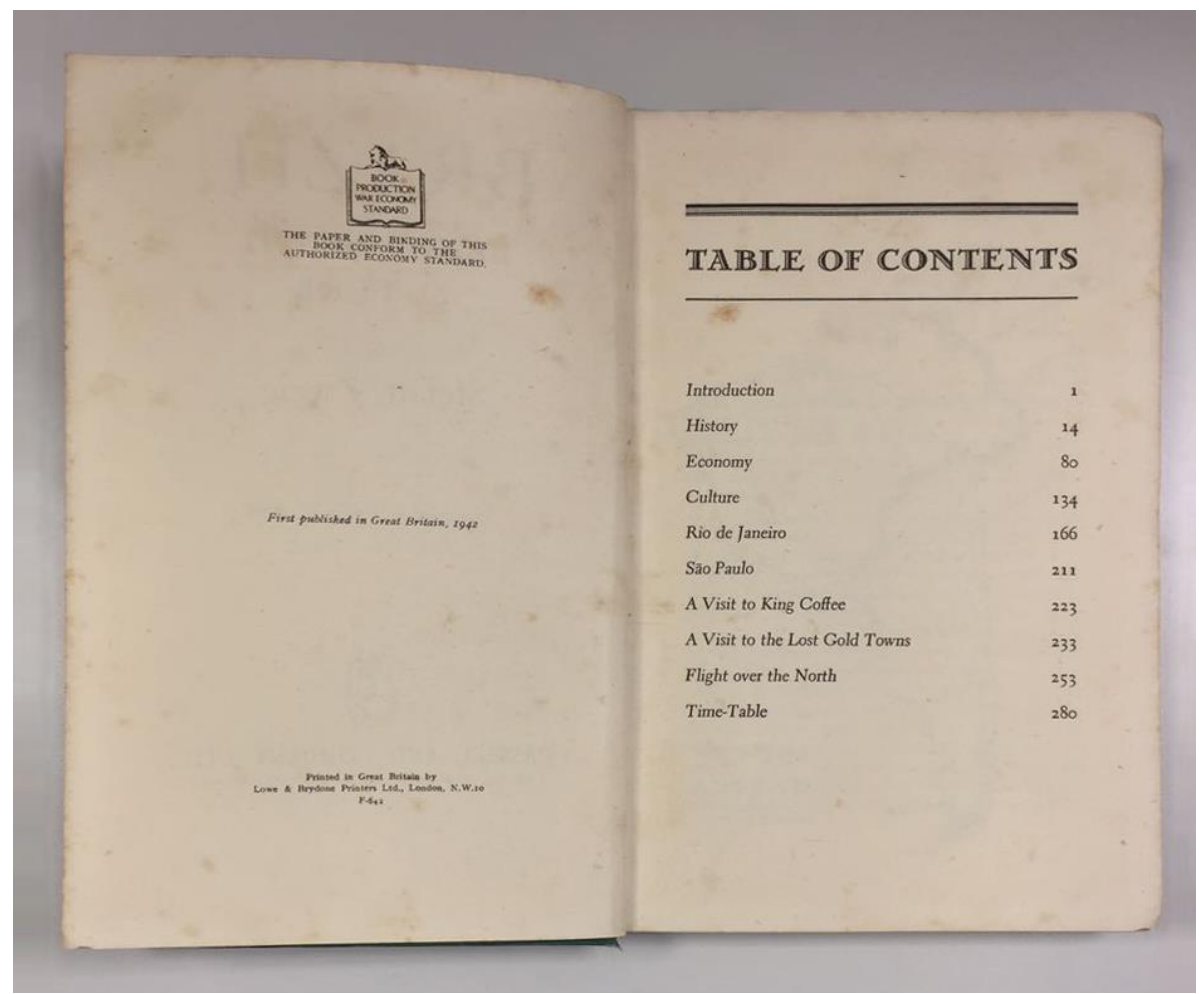

Fonte: foto e arte de Diogo Saúde, 2017. 
O original, escrito em alemão, não se constituirá objeto de análise. O real mote é destacar fragmentos das duas traduções, tanto em português quanto em inglês, os quais, comparados, apresentam formas diferenciadas de tradução, além de elementos que possam caracterizar representações ou que possam ser geradores de representações.

No prefácio da edição brasileira, Afrânio Peixoto faz uma referência à obra como resultado de um trabalho em que seu autor, explicitamente, declara seu encantamento por um país que, na sua concepção, é visto como um paraíso. Ele ressalta, de uma forma desafiadora, que "Os patriamadas, os ufanistas, ficarão de cara à banda, pois ninguém, até hoje, escreveu livro igual sobre o Brasil... O amor faz desses milagres [...]". Quando se refere a "milagre", não estaria Afrânio provocando uma reflexão sobre a questão desse amor? Se não existisse o tão declarado amor, seria o olhar do autor mais realista? Dines (2009, p. 15) escreve que " $O$ país do futuro é uma fuga, filho do medo, resposta de um sonhador ao terror nazista". Um sonhador, sim, mas pela paz no mundo, pela união dos povos, pelo convívio harmonioso dos homens, independentemente da cor da pele, da opção religiosa, da origem e de outros valores que possam gerar preconceitos e rejeição do "outro", aquele que se apresenta diferente.

Faz-se necessário ressaltar que o texto da primeira tradução encontra-se escrito conforme as regras ortográficas em vigência na época, assim sendo, todas as citações a serem apresentadas nesta dissertação serão transcritas conforme constam na obra traduzida.

\subsubsection{O olhar de Zweig - um desafio para os tradutores}

Zweig introduz seu livro esclarecendo os motivos que o levaram a fazer a sua primeira visita ao Brasil, e as ideias existentes até então sobre o Brasil, ideias essas que estavam pautadas em representações que circulavam entre os europeus e os norte-americanos. Para eles, a imagem do território brasileiro era de uma terra de clima quente, insalubre, arruinado financeiramente, civilizado parcialmente, exceto nas cidades litorâneas, com uma política preocupante e mal administrada. Contudo, um histórico desde a chegada dos portugueses, o seu processo de colonização até o início do século XX, as belezas do País em sua diversidade cultural, suas riquezas naturais e as qualidades do povo brasileiro, registradas em suas andanças e viagens pelos estados e interior, são destacados.

Após deixar a sua querida Europa, encoberta pelas inquietações e pelo temor de um povo diante do que estava por vir, Stefan Zweig (1941, p. 20), ao visitar o Brasil, classifica-o como "um dos países mais modelares e, por isso, um dos mais dignos de estima", pois pensa 
que se avalia "o grau de superioridade de uma nação pelo seu espírito pacífico e humanitário". Para ele, os brasileiros apresentam várias características que os diferenciam de outros povos.

Quando se questiona ser um desafio aos tradutores a obra original de Zweig sobre o Brasil, isso ocorre por considerar-se a diversidade das línguas e das culturas envolvidas, pois o Brasil em si é constituído de regiões, com culturas diversificadas e um vocabulário próprio que identifica seus habitantes. Para Rónai (1976, p.11), o tradutor precisa adquirir "um sexto sentido, uma espécie de faro, que o advirta de estar na presença de uma acepção desconhecida de uma palavra, ou de uma locução de elementos inseparáveis, intraduzível ao pé da letra [...]". Trata-se de uma observação que pode ser aplicada para qualquer tradutor em seu ofício tradutório, diante das línguas. No caso de Zweig, se deve considerar o seu encantamento pelo "paraíso" encontrado em terras brasileiras, que carrega suas narrativas e descrições, semanticamente, de forma mais intensa.

Nas edições em inglês e em português, encontram-se fragmentos que destacam formas diferentes de tradução no texto que diz respeito à descrição da característica física e da personalidade do brasileiro.

Quadro 1 - Descrição da característica física e da personalidade do brasileiro

Fonte: Brazil land of the future
Translated by Andrew St. James
What caracterizes the Brazilian physically and
spiritually more than anything else is that he is
more delicate than the European, the North
American. [...] The same is the case in the spiritual
sense, and it's a blessing to find this repeated a
thousandfold within a nation: every form of
brutality, loudness, rudeness, and arrogance is
missing. The Brasilian is a quiet person, dreamy
ande sentimental, somethimes with a touch of
melancholy, [...] (1942, p. 139)

Fonte: Brazil land of the future

Translated by Andrew St. James

Fonte: Brasil país do futuro Tradução Odilon Gallotti

$\mathrm{O}$ que no ponto de vista físico e psíquico caracteriza o brasileiro é sobretudo ser ele de compleição mais delicada do que a do europeu e a do norteamericano. [...] Igualmente falta neles toda brutalidade, violência e veemência, tudo o que é grosseiro, presunçoso e arrogante. O brasileiro é um indivíduo calmo, pensativo e sentimental, às vezes até com um ligeiro laivo de melancolia, [...] (1941, p.153)

Observa-se que o tradutor James apresenta, em sua tradução, um dado que não consta na tradução de Gallotti, quando cita o fato de ser considerada uma "bênção" ao se constatar, com frequência, a ausência dessas especificações negativas no povo brasileiro em relação aos europeus e norte-americanos. Provavelmente, uma forma de considerar ser uma dádiva de Deus, concedida a uma minoria, tendo em vista a guerra na Europa e suas consequências drásticas.

A visão eurocêntrica de Zweig é latente ao se posicionar diante de situações observadas por ele na sociedade brasileira. Nélson Jahr Garcia (2001, apud ZWEIG, 2001, p.6), ao apresentar a obra de Zweig, em versão eletrônica, diz que seu único problema é o 
eurocentrismo, enquanto sua visão do mundo com base no padrão europeu. Ele ressalta que Zweig vê os rios sinuosos do Brasil como um problema, face ao traçado retilíneo dos rios da Europa. Montanhas, planícies, praias, mangues são considerados, pelo autor, comparativamente a uma realidade que não é nossa.

Bignami (2005) afirma que

\begin{abstract}
Pode-se dizer que a América foi sendo desenhada e descrita por pensadores, artistas, navegadores e autores, durante um longo processo de conhecimento e estabelecimento de identidades. Nesse diálogo entre Novo e Velho Mundo, predominou evidentemente um sentido europeu, revestido de forte ideologia de dominação. (BIGNAMI, 2005, p. 79)
\end{abstract}

Por muito tempo, o território brasileiro esteve sob o domínio dos portugueses e de colonizadores com base nos valores e padrões europeus. Até a língua, por pouco, não foi oficializada a francesa. Muitas capitais ainda apresentam, em alguns lugares, uma arquitetura muito distinta, identificada pelos moldes de alguns países do continente europeu, porém já inserida em nosso contexto cultural. A cultura de um povo é constituída a partir de sua história e "nenhuma mente está livre dos efeitos de condicionamentos anteriores que lhe são impostos por suas representações, linguagem ou cultura" (MOSCOVICI, 2013, p.35).

Dines (2013), em um vídeo da editora Zahar, diz que Zweig, oriundo de Viena, cidade vista como "uma das matrizes centrais do pensamento moderno", era considerado um "colecionador de almas", e estava inserido em um círculo muito grande de intelectuais franceses, austríacos, alemães, ingleses e russos. Diante dessa realidade do autor e com base na Teoria das Representações Sociais, compreende-se que, estando Stefan Zweig no Brasil, num contexto cultural muito diferente ao que estava acostumado, vivenciando comportamentos e situações que não se encaixavam em suas representações, que não lhe eram familiar, ele procurou meios que o fizessem encontrar uma explicação, uma familiarização, um motivo para entender tudo o que se apresentava de estranho à sua volta. O desejo de entender os fatos justificaria as comparações constantes com a sua cultura de origem, de onde foi gerada a maioria de suas representações sociais, responsáveis por seus referenciais.

Moscovici (2003, p. 81) esclarece essa busca de causa como casualidade primária, abordada na p.36 desta dissertação. De acordo com as finalidades, o indivíduo procura uma explicação dentro de suas representações existentes. Assim, passa a fazer sentido o fato de Stefan Zweig enxergar no Brasil tudo o que se estava perdendo na sua Europa, uma maneira 
de preencher esse vazio de significados e de identidade que o sustentavam como sujeito, que, de repente, se percebe sem casa e sem base, um apátrida.

Portanto, Zweig não poderia ter outro olhar senão aquele que trazia consigo, repleto de referências marcantes, resultado de tudo o que vivenciara. Era um homem angustiado com as consequências do terror nazista, uma demência causada por uma ideologia racial, que se estava estendendo por vários países do Velho Mundo. Essa experiência de vida o fez tornar-se um pacifista.

Zweig conseguiu enxergar no brasileiro, em sua forma de viver, esse estilo pacifista. Para ele, o brasileiro, mesmo durante as festas populares, quando liberava efusivamente a sua alegria, não extrapolava o limite do bom convívio e da boa conduta. Na tradução em português, onde consta o fragmento que faz referência aos 4 dias de carnaval, aparecem as expressões "válvula de segurança", "instintos represados" e "picadas de tarântulas", que não são encontradas na estrutura textual de James, na versão inglesa.

Evidentemente, são formas de manifestação que Zweig não trazia consigo em suas representações, pois, ao mesmo tempo que fala da espontaneidade do brasileiro em externar a sua alegria, o autor deixa subtendido que por trás disso havia um limite de censura individual para não ocorrer excessos.

Quadro 2 - Versão brasileira com expressões enfáticas

\begin{tabular}{|l|l|}
\hline $\begin{array}{l}\text { Brazil land of the future } \\
\text { Stefan Zweig } \\
\text { Translated by Andrew St. James }\end{array}$ & $\begin{array}{l}\text { Brasil, país do futuro } \\
\text { Stefan Zweig } \\
\text { Tradução Odilon Gallotti }\end{array}$ \\
\hline $\begin{array}{l}\text { To make a noise, to shout, to dance wildly, is } \\
\text { entirely contrary to their habits; so much so, in fact, } \\
\text { that whatever gaiety has been saved up is suddenly } \\
\text { released during the four days of carnival. }\end{array}$ & $\begin{array}{l}\text { Fazer barulho, gritar, fazer algazarra e dansar } \\
\text { desenfreadamente são no Brasil prazeres tão } \\
\text { contrários aos costumes que, por assim dizer, se } \\
\text { reservam para os quatros dias de carnaval, que } \\
\text { servem de válvula de segurança para todos os } \\
\text { millions of people, in spite of their frenzied } \\
\text { behaviour, never run to excess, never become } \\
\text { indecent or vulgar. (1942, p.140) }\end{array}$ \\
$\begin{array}{l}\text { instintos represados; mas, mesmo nesses quatro } \\
\text { dias de alegria aparentemente infrene, numa } \\
\text { massa de um milhão de pessoas como que picadas } \\
\text { por uma tarântula, não se observam excessos, } \\
\text { inconveniências e baixezas; [...]. (1941, p.153) }\end{array}$ \\
\hline
\end{tabular}

As expressões "válvula de segurança", "instintos represados" e "picadas por uma tarântula" podem ser recursos usados por Gallotti para transmitir a intencionalidade enfática do autor do original ao público leitor alvo, dentro de uma linguagem mais próxima à cultura da língua de chegada. 
O autor, com a sua obra, cumpriu a sua promessa de ser um camelô do Brasil no exterior. Não somente nos anos 40 e 50, mas ainda na atualidade, muitos visitam o país buscando a beleza e o acolhimento divulgados em sua obra.

No cenário que descreve as favelas, em sua concepção, estão nelas todas as coisas que faltam na Europa e nos Estados Unidos, a maneira simples de habitar e viver, onde os moradores se sentem mil vezes mais felizes que o proletariado desses países em suas casas de cômodos. As favelas situadas a cinco minutos da praia de luxo, que marcam as zonas pobres em plena cidade, sem iluminação elétrica, com circulação de várias espécies de animais domésticos dividindo espaço entre os seus habitantes, são comparadas à aldeia da Polinésia ou da África (ZWEIG, 1941, p.14).

Ao analisar essa passagem, nas duas versões de tradução, na versão em inglês, observa-se que Gallotti faz referência a "moradores" e James, a "Negroes". No que diz respeito aos habitantes desses espaços, mesmo que os negros fossem em maioria, famílias de brancos e mestiços também habitavam as favelas. Gallotti, conhecendo a realidade brasileira, evitou usar o termo negro em sua tradução.

Quadro 3 - Referência a moradores da favela

\begin{tabular}{|l|l|}
\hline $\begin{array}{l}\text { Fonte: Brazil land of the future } \\
\text { Stefan Zweig }\end{array}$ & $\begin{array}{l}\text { Fonte: Brasil, país do futuro } \\
\text { Stefan Zweig } \\
\text { Translated by Andrew St. James }\end{array}$ \\
\hline $\begin{array}{l}\text { Tut, oddly enough, there is nothing depressing } \\
\text { about this sight, nothing provocative, repulsive, or } \\
\text { shameful-because these Negroes consider }\end{array}$ & $\begin{array}{l}\text { Mas, coisa curiosa, o espetáculo nada tem de } \\
\text { aflitivo, de repulsivo, de vergonhoso, pois esses } \\
\text { moradores se sentem ali mil vezes mais felizes }\end{array}$ \\
$\begin{array}{l}\text { themselves a thousand times better off than does } \\
\text { our proletariat in its tenement homes (1942, p. }\end{array}$ & $\begin{array}{l}\text { do ômodos (1941, p. 201). } \\
\text { con). }\end{array}$ \\
\hline
\end{tabular}

Nas versões em português e em inglês, podem ser observados dois fragmentos que fazem referências às favelas, nos quais os tradutores interpretam de formas diferenciadas.

Quadro 4 - Referências às favelas

\begin{tabular}{|l|l|}
\hline Brazil land of the future & $\begin{array}{l}\text { Brasil país do futuro } \\
\text { Stefan Zweig }\end{array}$ \\
Translated by Andrew St. James & Tradução Odilon Gallotti \\
\hline $\begin{array}{l}\text { Several of the unique things which make Rio so } \\
\text { colorful and picturesque are actually in danger of } \\
\text { passing, especially the favellas, the Negro villages, }\end{array}$ & $\begin{array}{l}\text { Algumas das coisas singulares, que tornam o Rio } \\
\text { tão colorido e pitoresco, já se acham ameaçadas } \\
\text { de desaparecer. Sobretudo as "favelas", as zonas } \\
\text { in the middle of the town. Will they be there in a a } \\
\text { few years' time? (1942, p.195). }\end{array}$ \\
\hline
\end{tabular}


No ir e vir entre as diversidades culturais existentes em relação às línguas envolvidas num processo de tradução, o tradutor pode recorrer ao seu conhecimento do contexto sociocultural da língua de chegada e fazer uso de referências próprias para atender a um melhor acolhimento interpretativo na cultura da língua alvo.

A cordialidade e as boas maneiras do brasileiro são destacadas por Zweig (1941, p.154) em contraponto as dos europeus, quando afirma que "A polidez é aqui a forma básica natural das relações humanas e assume maneiras que nós na Europa há muito tempo já esquecemos [...]". São atitudes que despertam desconfiança no estrangeiro ao chegar ao País.

Zweig (1941, p.152) ressalta que o brasileiro é "um indivíduo calmo, pensativo e sentimental, às vezes até com ligeiro laivo de melancolia [...]”, igualando à percepção que Anchieta e o Padre Cardim tiveram lá pelos anos de 1585. Naquela época, o perfil poderia ser definido dessa forma, pois, 85 anos após o achamento do Brasil, a população vivia numa sociedade hierarquizada, na qual "a aproximação física como manifestação de afeto era resguardada e contida" (HINTZ, 2001, p.10 apud BARROS, p.7). Em pleno século XX, entre os anos 30 e 40, a realidade já era outra, apesar das instabilidades social e política em que se encontrava a sociedade brasileira.

A leitura do fragmento citado na primeira linha do parágrafo anterior, nas duas traduções, nas quais, em português, Gallotti utiliza a palavra "pensativo" e James, em inglês, “dreamy", poderá levar o leitor a dar a cada uma delas, uma conotação diferenciada, dependendo da interpretação feita. De acordo com o Minidicionário da Editora Larousse do Brasil (2009, p.623), encontramos pensativo como adjetivo - aquele que pensa - e como substantivo - pessoa que reflete, que pensa profundamente. Filósofo. No Oxford Advanced Learner's Dictionary of Current English (1985, p.265), encontra-se “dreamy” como adjetivo -“(of a person) with thoughts far away from his surroundings or work)".

Mas há determinadas definições de Zweig sobre o perfil do brasileiro que levantam dúvidas se o próprio não estava transferindo para o "outro" o seu estado de espírito ou traçando um perfil com base em algum tipo de outro lugar, menos de um indivíduo pertencente a um país tropical como o Brasil, cheio de luz, com muito verde e multicultural, no qual a dança e a música, como se tivessem raízes, brotam por todo canto.

Outra colocação que chama a atenção do leitor por não combinar com o que é de conhecimento em relação ao comportamento do brasileiro ocorre quando afirma que 
quatro dias de carnaval, que servem de válvula de segurança para todos os instintos represados [...] (ZWEIG, 1941, p.153) ${ }^{6}$.

Essa observação talvez possa estar caracterizando uma fase de comportamento dos cidadãos daquele período, devido ao cerceamento da política do Estado Novo, o qual proibia aglomeração de pessoas nas esquinas da cidade e manifestações populares, tolhendo, assim, não apenas a liberdade de expressão verbal, como a das emoções.

Apesar das discordâncias apontadas, o olhar de Zweig fez registros dos aspectos físicos privilegiados pela natureza à cidade do Rio de Janeiro e de outras particularidades das regiões por onde visitou. A sua capacidade de percepção da energia e da alma do brasileiro, assim como da diversidade cultural do Brasil, está nitidamente apresentada nas traduções analisadas para este trabalho. Portanto, considera-se a possibilidade de que, para Odilon Gallotti, por ser brasileiro e conhecedor da cultura de seu País, provavelmente, o desafio encontrado em seu ofício deve ter sido mais no aspecto linguístico e estrutural da língua alemã, pois, de acordo com Paschoal (2007, p.219),

para recriar em língua portuguesa algo implícito no texto alemão exige que tenhamos condições de detectar no texto em alemão o "implícito" e de recriá-lo ou transportá-lo - adotando-se as medidas necessárias para sua plena significação no texto em português - para a língua portuguesa.

Mesmo sendo um texto sobre o Brasil, sua cultura e sua gente, escrito originalmente em alemão, as traduções citadas no presente trabalho trazem em suas estruturas o estilo de seu autor e uma linguagem que se adequa à cultura e à compreensão de seus leitores. Assim, nas duas versões analisadas, as diferenças encontradas, possivelmente, foram originadas de interpretações próprias dos tradutores ao tomarem como referência as variações linguísticas e as culturas envolvidas.

Uma adequação já pode ser observada no subtítulo das edições traduzidas em português, inglês, francês e espanhol, por não conter o artigo indefinido (ein, um) que aparece no subtítulo do original, Ein Land der Zukunft. Dines (2009, p.161) explica que a presença do artigo torna "menos enfático, indeterminado, não singulariza - o Brasil fica incluído entre os países promissores, não é o único”.

\footnotetext{
${ }^{6}$ Fragmento transcrito conforme apresentado na edição.
} 
Porém, em relação à tradução de Alfredo Cahn (1902-1975), a primeira edição da versão em espanhol para Argentina saiu apenas com o título Brasil, pois "o aposto País do Futuro poderia ferir o patriotismo argentino" (DINES, 2009, p. 164) ${ }^{7}$.

\subsubsection{Os ecos das representações em Brasil, país do futuro}

Mesmo que Nélson Jahr Garcia (2001, p.7) tenha dito que "Zweig colocou os óculos vermelhos de Kant e viu um Brasil róseo, viu beleza na miséria, riqueza no triste, alegria na dor", o autor destaca alguns problemas aos quais, de forma bem objetiva, não se exime de fazer comentários e, ao mesmo tempo, de deixar um alerta para situações não positivas existentes na administração política, econômica e social do País. Um exemplo dessa chamada de atenção é feito por uma metáfora usada por Zweig para tecer um comentário à ineficiente rede de transporte que poderia facilitar a exploração de preciosos produtos no interior do Brasil.

Esse gigante, pois continua a sofrer de uma constante perturbação circulatória: o sangue não percorre uniformemente todo o seu organismo, e partes importantes são inteiramente aplásicas (ZWEIG, 1941, p.140).

Após tantas décadas, com base nessa mesma metáfora, é possível concluir que a circulação desse gigante não foi eficientemente tratada e acompanhada, pois ainda há trombos que necessitam ser eliminados para que o fluxo sanguíneo possa levar mais oxigênio/vida a todos os extremos desse imenso corpo territorial. Os problemas relacionados às vias de transporte, tanto terrestre como ferroviária, ainda carecem de muito investimento e melhorias.

E continua Zweig aludindo ao País em suas comparações - "O Brasil padece de uma anemia, de uma deficiência de gente para um território tão vasto. O remédio para o Velho Mundo e ao mesmo tempo para este novo mundo, o Brasil, seria uma grande transfusão de sangue e de capital [...]". Tal afirmação é mais uma comparação metafórica feita por Zweig (1941, p. 141) para ressaltar que, enquanto a Europa sofria com excesso de gente e falta de espaço, além dos sérios problemas que seu povo enfrentava pela grande guerra e suas consequências trágicas, o Brasil tinha carência de mão de obra e muito espaço para ser povoado.

\footnotetext{
${ }^{7}$ Destaques do título e subtítulo nossos.
} 
Não seria apenas o grande investimento na educação e as mudanças efetuadas que promoveriam um avanço em vários setores importantes, principalmente na economia nacional. Havia necessidade de se gerarem mudanças na própria cultura, nas representações oriundas de séculos de dominação e de influências externas. Na realidade, tais conquistas não seriam possíveis em sua totalidade no governo Vargas devido às ações impostas em sua política de gestão, com destaque a que restringia a liberdade de expressão, cerceava o comportamento do cidadão, impedindo uma plena participação dos indivíduos na construção da sociedade.

Citações feitas por Zweig (1941) com relação a certos hábitos dos brasileiros, tais como: a ideia de trabalhar não para economizar dinheiro, mas para ter o suficiente para as necessidades; a mania de deixar tudo para o dia seguinte, a questão de não cumprir com os horários dos compromissos e o enriquecimento decorrente não do trabalho, mas do jogo, fornecem imagens que deram margem para despertar os brios de alguns "ufanistas" e para o fortalecimento de algumas representações sobre o perfil do brasileiro que ainda prevalecem, tanto dentro do próprio País como fora dele.

Tristão de Athayde (Alceu de Amoroso Lima, 1893-1983), mesmo não sendo adepto à literatura de Zweig, em uma resenha que fez sobre o livro, faz referência à existência de outras representações que circulam entre os brasileiros, criadas consensualmente por eles próprios, quando diz que

\footnotetext{
“ [...] o livro não me surpreendeu...mas não correspondeu de modo algum ao que me faziam ver os críticos... Obra muito sincera e que absolutamente não denota nenhum constrangimento.., É uma visão impressionista e otimista da nossa terra... que denota uma grande simpatia e compreensão justa de vários traços de nossa psicologia coletiva...A crítica que faz, sempre com luvas de pelica, a certos hábitos e modos de nosso povo... está muito longe daquelas que nós diariamente nos fazemos..." (ATHAYDE, 1941, O Jornal apud DINES, 2009, p.188)
}

Monteiro Lobato, já citado neste estudo, também foi alvo de críticas com a criação de alguns de seus personagens. De seu livro de contos Urupês surge o Jeca Tatu, que retrata o protótipo do caipira brasileiro. Em seu artigo publicado na Revista Escola, Duarte (s/d) ressalta que "Lobato foi alvo de críticas por pessoas influentes e médicos sanitaristas, mas para a literatura, revelava um personagem totalmente alienado à sociedade corrompida, que por falta de recursos financeiros vivia de maneira medíocre e marginalizada". Assim, caminha o universo literário, com os seus originais e as suas traduções, levando as suas contribuições para possíveis mudanças nos âmbitos pessoal e sociocultural de seus leitores. 
Apresentam-se algumas das observações que definem o jeito de ser do brasileiro, nas versões em inglês e português.

Quadro 5 - O jeito de ser do brasileiro

\begin{tabular}{l} 
Fonte: Brazil land of the future \\
Stefan Zweig \\
Translated by Andrew St. James \\
\hline -A large majority of the caboclos, especially in the \\
tropical zones, does not work in order to \\
economize or save money, but simply to keep alive \\
during the few succeeding days (1942, p.145). \\
- why do this today? Why not tomorrow? \\
"Mañana, mañana!" [...] (1942, p.145). \\
-Punctuality is performed here in such a way that \\
all lectures, all concerts, start punctually a quarter \\
of an hour later than announced. If one adjusts \\
one's watch to this principle one misses nothing \\
(1942, p.146). \\
- Wealth is something one dreams about; it should \\
fall from Heaven; and in Brazil the function of this \\
Heaven is replaced by the lottery (1942, p.146).
\end{tabular}

Fonte: Brazil land of the future

Translated by Andrew St. James

tropical zones, does not work in order to economize or save money, but simply to keep alive during the few succeeding days (1942, p.145).

- why do this today? Why not tomorrow?

-Punctuality is performed here in such a way that all lectures, all concerts, start punctually a quarter (1942, p.146).

Heaven is replaced by the lottery (1942, p.146).
Fonte: Brasil, país do futuro

Stefan Zweig

Tradução Odilon Gallotti

- Grande parte dos caboclos, sobretudo nas zonas tropicais, trabalha não para economizar e guardar, mas sim apenas para não passar dificuldades durante alguns dias (1941, p. 159)

- Por que necessariamente hoje aprontar ou fazer isso? Por que não amanhã [...](1941, p. 159).

- A pontualidade aqui já é muito grande, se qualquer conferência, qualquer concerto começa bastante pontualmente quinze minutos depois da hora marcada; se nos adaptamos a isso, nunca chegamos atrasados (1941, p. 160).

- O dinheiro é algo com que se sonha; tem que vir do céu, e, no Brasil, é a loteria que substitui o céu (1941, p. 160).

Que motivos teria James para usar o termo "Mañana"? Não seria ele um daqueles que acreditavam que, em terras brasileiras, o idioma vigente era o espanhol? Zweig provavelmente não iria usá-lo, pois faz referência a essa falta de conhecimento em seu livro.

Encontrei num romance - de autor inglês muito conhecido - o engraçado pormenor de fazer o seu protagonista ir para o Rio de Janeiro a fim de nesta cidade aprender o espanhol. Mas esse autor é apenas mais um dos inúmeros indivíduos que não sabem que no Brasil se fala português (ZWEIG,1941, p.10).

Com base no que se conhece do tipo do povo desta terra, comumente um brasileiro não se expressaria assim. Possivelmente, trata-se de uma concepção do próprio tradutor em decorrência de suas representações.

O respeito e admiração de seu público leitor e de vários intelectuais por suas obras e a publicação da versão em português de seu livro Brasil, país do futuro não só despertaram o interesse dos leitores brasileiros, como também abriram um espaço oportuno para que alguns jornalistas não medissem as suas críticas à obra. Nem todos eram críticos literários, mas, como se mostravam insatisfeitos com as intervenções em vários jornais da época, executadas pelo Governo vigente, movidos por esses motivos e pela ideia de que Zweig estava ligado a Vargas, colocaram o autor austríaco na linha de tiro de suas críticas. O mais ostensivo foi 
Pedro da Costa Rego, redator-chefe do Correio da Manhã, jornal carioca diário e matutino, editado desde 1901 a 1974.

Como existia uma suposição de que Brasil, país do futuro era fruto de troca de favores entre Zweig e Vargas, reforçada pela concessão de cidadania brasileira ao autor, essa hipótese foi o motivo para atiçar a ira dos insatisfeitos com o Governo. Dines $(2009$, p.168;172) infere que a irritação de Costa Rego foi instigada por comentários de Zweig em seu livro, entendidos como crítica à indolência do brasileiro e à sua fixação na "sorte grande", ao se referir à busca do enriquecimento por meio de aposta na loteria.

Costa Rego, em sua coluna no jornal Correio da Manhã, de 6 de agosto de 1941, apresenta o livro de Zweig como "livro de autor famoso cujo tema é a nossa vida, nossa origem, nossa maneira de compreender o mundo, até mesmo o nosso futuro", porém continua, de forma diplomática, destacando ser um "livro amável, mas com inexatidões ou exageros capazes de deitá-lo a perder".

O jornalista Carlos Maul, em sua coluna do dia 8 de agosto de 1941, do mesmo jornal de Costa Rego, questiona "Que Brasil do Futuro é esse?" e ressalta que o livro de Stefan Zweig "é um excelente repositório de material contra nós fora daqui por qualquer escriba de má vontade”. Para Maul, os comentários impróprios de Zweig poderiam interessar a outros, se referindo a estrangeiros, que aproveitariam para "copiar" esses dados, considerados negativos, e que, repassados como "leis", possivelmente iriam gerar representações a respeito do País e de seu povo. Naquele momento, o Brasil precisava do olhar positivo do "estrangeiro" para o seu desenvolvimento econômico.

No meio dessa saraivada de críticas e de elogios divulgados em vários jornais brasileiros, um jornal da Bahia, A Tarde, apresenta aos seus leitores uma coluna na qual afirma que

\footnotetext{
Todos nós, bahianos, devemos ser agradecidos a Stefan Zweig, o escritor de renome mundial, pelas paginas que sobre a nossa terra acaba de publicar no seu recente livro, 'Brasil, país de futuro'. Não por que nos elogiasse, mas apenas porque nos compreendeu. [...] Zweig mostrou ter escutado a alma da antiga capital do Brasil[...]" ( A Tarde, Bahia, 06 de Agosto de 1941, apud DINES, 2009, p. 171). ${ }^{8}$
}

Além de "caçador de almas" como já foi citado no item 3.4.1, à p. 69, passa a ser, para os baianos, "aquele que escuta a alma" de um lugar. Essa expressão não deixa de ser uma maneira de exaltar a sensibilidade do autor, o qual, após uma interação com os cidadãos da

\footnotetext{
${ }^{8}$ Transcrição do trecho conforme consta na redação original.
} 
terra e um mergulho em sua cultura popular, parece ter apreendido a verdadeira identidade e os sentimentos que movem o povo baiano.

Stefan Zweig, pelo que já representava no contexto mundial, era motivo justo para despertar a atenção necessária para o lançamento da tradução de seu livro no Brasil. No entanto, toda a celeuma criada pelos críticos acabou, incrivelmente, sendo um mote extra para atiçar com mais intensidade a curiosidade dos leitores brasileiros pelas traduções de várias obras de Zweig, além do seu livro sobre o Brasil. Diante desse sucesso, os interesses nacionalistas do Estado Novo também estavam sendo contemplados, mesmo partindo de uma obra que, de certa maneira, ora enaltece ora cria espaço para estabelecer representações sobre um povo pela exposição e pela narrativa da realidade vivenciada entre eles.

A versão em português foi entregue a uma editora de nome sugestivo, Ridendo Castigat Mores, uma expressão latina que significa "rindo, moralizam-se os costumes" (AZEVEDO, 2009), que também ocorre como «castigat ridendo mores» e corresponde ao «princípio em que se fundamenta a comédia, criado por Jean de Santeuil» (1630-1697), poeta francês que escreveu em latim. Portanto, pelo fato de a edição da tradução em língua portuguesa despertar em seus leitores uma reflexão sobre o País, mesmo entre exaltação e indignação, a expressão sugestiva Ridendo Castigat Mores fez jus ao seu sentido.

Brasil, país do futuro tornou-se uma expressão chave para toda e qualquer projeção de desenvolvimento em projetos do governo e em campanhas promocionais da imagem da nação. Em muitos artigos científicos publicados no Brasil e no exterior, questionamentos são encontrados sobre esse título, considerado uma "utopia". Seixas (2015, p.161) escreve que "a figuração Brasil, país do futuro, passa exprimir uma identidade nacional fundada na procrastinação e na postergação, na denegação do tempo presente, projetando-se em imprecisos amanhãs". Realmente, o que move a esperança de mudanças na maioria dos indivíduos, que batalham para terem condições de vida, é a fé de que no "amanhã" a situação será melhor. Aquilo que pesa é considerar que essa postergação gera ausência de ações efetivas no tempo presente.

Após leitura de sua obra, de sua biografia e de vários depoimentos de Zweig, nos quais os motivos que o levaram a escrever sobre o Brasil são apresentados e é possível entender que, por acreditar realmente ser o Brasil um país com possibilidades de se tornar uma referência para o mundo, verifica-se que se trata do lugar onde os fatores qualitativos registrados por ele, já inexistentes em muitos dos países da Europa envoltos em uma insana 
guerra, seriam a indicação de que o paraíso aqui encontrado seria para todos os que desejavam escapar da perseguição nazista, e também um refúgio e meio de sobrevivência.

No tópico seguinte, será abordada a questão de como a tradução das obras de Zweig, ressaltando a de Brasilien ein land der zukunft, conseguiram superar, em vendas, seus originais.

\subsubsection{Quando a tradução supera o original}

Os motivos que são apresentados por Zweig como justificativa de ter escrito Brasil, país do futuro evidenciam o seu encantamento pela beleza da cidade do Rio de Janeiro e por toda a diversidade encontrada por onde andou, sem deixar de citar o seu sentimento de gratidão pela forma como aqui foi recebido e tratado pelas pessoas de diferentes classes sociais.

A tradução de uma obra, na prática, conforme afirma Rónai (1976, p.56), pode se apresentar como uma operação de muitas faces, que envolvem aspectos comerciais, técnicos, psicológicos e outros. Ao levantar tanta polêmica na ocasião de seu lançamento quanto às dúvidas sobre a espontaneidade dessa ação de escrever um livro sobre o Brasil, em plena Era Vargas, foi e tem sido mote de discussão que perdura até a atualidade, justificado por Dines (2009, p.202) como "prova tardia de seu sucesso". Mas não se pode desconsiderar que a edição da tradução de Brasilien ein land der zukunft em português teve, potencialmente, um interesse para atender aos interesses do Estado, como mais um instrumento de divulgação dos ideais nacionalistas, conclusão gerada por não se ter sofrido nenhum controle do Estado em relação à censura praticada pelo regime de Vargas. Afinal, era o Brasil sob o olhar de um intelectual estrangeiro, de renome internacional que divulgou que seria o "camelot" do Brasil na Europa.

O reconhecimento do autor no âmbito da literatura mundial já constituía uma garantia do interesse e do sucesso dessa publicação. Mas a investida de Costa Rego e outros, a morte súbita e de maneira trágica do autor e esposa aguçaram ainda mais a curiosidade de seu público e de novos integrantes, tornando-se um estímulo para que as vendas de suas obras se multiplicassem.

O suicídio do casal, na madrugada de 22 para 23 de fevereiro de 1942, foi assunto muito explorado pelas imprensas nacional e internacional pelo fato de ter sido meticulosamente pensado, tendo em vista várias cartas de despedida e testamentos deixados 
pelo casal, entregues em envelope ao seu editor e amigo, Koogan, para serem guardados em cofre dois dias antes da tragédia.

De acordo com Stooss-Herbertz (2007: p. 11), na época do fatídico acontecimento, Brasil, país do futuro alcançou o número de 100.000 exemplares vendidos. Conforme Dines (2009, p.164), na Argentina, a editora Espasa-Calpe teve que reimprimir a obra três vezes naquele mesmo ano e, em 10 anos (1942-1952), foram publicadas 15 edições.

Quanto ao original dessa obra, em alemão, devido às perseguições feitas às obras literárias consideradas perigosas pelo III $^{\circ}$ Reich, só foi divulgado na Alemanha algum tempo depois, após o término da Guerra, todavia sem repercussão. Mas há suposições de que, no pós-guerra, cada alemão que chegava ao Brasil trazia consigo uma edição do livro de Zweig.

As traduções das obras de Zweig, principalmente em língua inglesa, se multiplicaram após sua morte. Dines (2012, p.14) escreve que Orson Welles veio conferir as revelações de Zweig, seis meses após o lançamento da tradução nos Estados Unidos. Esse autor ainda relata que, em Cuba, sua autobiografia teve uma tiragem de 20.000 exemplares. Na Espanha, mais de sessenta anos após sua publicação, foi incluída na lista dos livros do ano.

Uma pessoa, um fato ou um acontecimento tornam-se importantes quando deixam suas marcas na memória dos homens. A expressão "Brasil, país do futuro" ora é colocada em foco como positiva, ora como elemento de muita discussão. Durante todos esses anos, vem sendo utilizada como um "slogan" relacionado a projetos, campanhas, discursos de autoridades quando os objetivos são visualizar perspectivas para o país e, ao mesmo tempo, trabalhar o "imaginário" do brasileiro para que acredite que o Brasil tem condições de usar, da melhor forma possível, todo o seu potencial para progredir em todas as áreas e tornar-se referência como nação em todos os sentidos. Ser um "país do presente".

O Presidente Obama, em discurso proferido no Teatro Municipal do Rio de Janeiro, muito comentado pelas mídias, na ocasião de sua visita ao Brasil em 2011, fez uma referência à profética expressão de Zweig, mas com o olhar para o presente, quando afirmou que, por muito tempo, os brasileiros têm estado na espera "por um dia melhor que estava sempre depois da esquina". Obama ressaltou que o futuro já se fazia presente naquele momento e que os brasileiros deveriam já estar sabendo disso. Mas, na realidade, o que os brasileiros sabem mesmo é manter a sua "fezinha" de que esse "país do futuro" está por vir.

Muitos dos que visitam o Brasil, chegam por aqui na busca das maravilhas captadas pelo olhar de Zweig, olhar esse perpetuado nas diversas releituras de seu original. A beleza brasileira, sua diversidade cultural, a vitalidade e a hospitalidade do seu povo tão anunciadas 
em sua obra não só colocaram "o país no cenário internacional", como têm sido o mais importante incentivo para despertar o interesse do estrangeiro.

As traduções dão sobrevida às obras e levam o imaginário aos leitores quando os inserem diante de culturas e de valores diferentes aos dos seus. É o estranho/estrangeiro que chega até eles pela habilidade tradutória de um tradutor. Um original pode ser traduzido em várias línguas ou em uma mesma língua, várias vezes, por tradutores diferentes, no entanto, em cada uma dessas traduções, encontra-se um texto novo que possibilitará ao leitor da língua de chegada interpretações únicas que irão preencher as lacunas encontradas no texto.

Dines (2009, p. 202), em relação à edição em português, do único livro do autor sobre um país, ressalta que a "prova tardia de seu sucesso é o debate que ainda provoca. Zweig pretendia oferecer certezas, legou-nos dúvidas. [...] Discutir o Brasil nunca sairá de moda". Os acertos e erros nessa busca desse futuro despertam muitas interrogações e críticas, que são destacadas por atos de manifestos, pelas imprensas escrita e falada, em letras de músicas, filmes e peças teatrais. Assim, o Brasil, país do futuro será, sempre, assunto do presente. 


\section{CONSIDERAÇÕES FINAIS}

A mediação entre culturas é uma particularidade do ofício do tradutor, que torna a tradução, diante da diversidade linguística, possível e fundamental para a sobrevida do original. Quando Ricoeur (2012, p.11) postula que, mesmo diante da diversidade linguística, a tradução não está para uma prática coercitiva, com destino ao fracasso, nem em busca de uma teoria, endende-se que os seguintes pontos devem ser considerados: as necessidades do homem de interagir e de familiarizar-se com tudo o que se faz presente em seu mundo tornam a prática da tradução decorrente; se a tradução consegue estabelecer o diálogo intercultural, consequentemente, não faz parceria com o fracasso, mesmo quando é praticada a "hospitalidade linguística", isto é, “onde o prazer de habitar a língua do outro é compensado pelo prazer de receber em casa, na acolhida de sua própria morada, a palavra do estrangeiro" (RICOEUR, 2012, p. 49); ao pensar em criar uma teoria para a tradução é ignorar o dinamismo das línguas e o das sociedades. Com base no destaque das teorias e das estratégias de tradução de alguns teóricos, feito no primeiro capítulo desta dissertação, e com o aparecimento de outras novas teorias que surgiram até então, não há, ainda, um consenso a respeito, de maneira que seus objetivos e estratégias sejam prontamente estabelecidos.

Quanto à questão da diversidade e da traduzibilidade das línguas, considerando que as capacidades de se comunicar e de utilizar formas variadas de linguagem são inerentes ao homem, não há como pensar na impossibilidade de se traduzir de uma língua para qualquer outra, nem tampouco de estabelecer para a tradução uma teoria que a enquadre em definições, regras e estratégias. Aquilo que torna a tradução um ato possível e prazeroso é saber que se pode contar com um cabedal de experiências tradutórias desde os seus primórdios até a atualidade para nortear novos estudos e, assim, o surgimento de novas ideias sobre a questão da prática tradutória. Essa difusão de diferentes olhares amplia, imensuravelmente, o universo de possibilidades para a tomada de decisões por parte do tradutor na definição de sua linha de ação.

Ao tradutor, compete imergir nas culturas envolvidas não somente para conhecer os costumes, as crenças, os valores, as representações que predominam aquela sociedade específica, mas, também, para identificar as diferenças linguísticas, principalmente se o original foi escrito em épocas distantes do tempo da tradução. Não são encontrados os mesmos costumes, "as mesmas construções mentais e os mesmos raciocínios" (WOLTON (2003, apud OUSTINOFF, 2011, p.127), de uma língua para outra. Portanto, esse trânsito 
entre culturas distintas é tido como fundamental, tendo em vista que é o espaço que proporcionará ao tradutor elementos para fazer os ajustes devidos, de maneira que o produto final alcance o seu fim estabelecido.

$\mathrm{Na}$ construção de seu texto, o tradutor não se isenta de lidar com sua própria identidade, pois o seu construto social é fator de influência, assim como tudo o que diz respeito ao autor do original. Quando o leitor encontra-se envolvido com um texto literário, original ou tradução, tem diante si elementos que o levarão a uma reavaliação de suas próprias experiências e representações.

Esse processamento, gerado pelo ato da leitura, desperta a atenção para o poder das palavras. As traduções, tanto literárias como as de cunho técnico-científico, possuem papel importante para a ampliação do conhecimento e do compartilhamento de experiências. As literárias, principalmente, tornam-se fundamentais ao trazer o estrangeiro e sua cultura, ampliando horizontes para os seus leitores e proporcionando um novo olhar para o mundo que os envolve.

A preocupação quanto ao efeito a ser gerado pelo contato do leitor com outras culturas, a princípio, pode estar embasada em interesses específicos que movem o cerceamento à ação tradutória por parte de um poder dominante ou por parte de exigências editoriais.

O poder do pensamento e da palavra é o que desperta, nos poderosos, o medo, pois sabem que uma sociedade pode ser transformada pela geração de novas representações. Consensualmente formadas, elas fortalecem os indivíduos e proporcionam-lhes um sentimento de pertencimento social. Com referência ao temor que esse poder pode gerar, a escritora e jornalista Dorothy Thompson, ao dar as boas-vindas aos escritores refugiados europeus, reunidos num jantar comemorativo nos Estados Unidos, em 1941, afirma que "Hitler não tem medo das armas, ele tem pavor das palavras" (apud DINES, 2009).

O recorte feito, para trazer em questão a Era Vargas, foi fundamental para mostrar a estratégia de Vargas, com a percepção quanto a esse poder, ao manter em seu Governo intelectuais e eruditos reconhecidos nacionalmente pelo sucesso de seus trabalhos. Por serem habilidosos com o uso das palavras, possuíam um potencial de influência na sociedade, fator de muita importância para disseminar os ideais da política nacionalista do Estado Novo.

A mesma estratégia foi o mote para ter, de certa maneira, o autor austríaco de origem judaica, Stefan Zweig, servindo como um propagador do Brasil para os próprios brasileiros, 
com o intuito de aumentar o sentimento nacionalista, e para o mundo, de forma a despertar o interesse de estrangeiros para investimentos no Brasil.

Stefan Zweig conseguiu, apesar de ter tido uma recepção negativa de sua obra, apresentar o Brasil para os brasileiros e para o mundo de uma forma romântica, mesmo diante das diversidades por aqui existentes. Fez destaques sobre a beleza do País e de sua gente, sem deixar de dar umas "espetadas" em algumas situações que necessitavam de mais atenção e investimento por parte do então Governo. Esse seu olhar foi repassado pelo ofício tradutório de Odilon Gallotti e pelo seu conhecimento da mente humana, como psiquiatra.

O Brasil sob o olhar de Zweig influenciou não só os brasileiros para que vissem o seu país de outra forma, como também despertou o interesse de muitos estrangeiros devido às versões de Brasilien ein land der zukunft (1941) em várias línguas, desconstruindo representações não compatíveis com a realidade da terra e com o povo que nela habita.

Esse movimento pode ter sido o incentivo inicial para um investimento mais ostensivo no âmbito da publicidade, para divulgação da imagem do Brasil no exterior desde a metade do século passado. O resultado desse investimento assumido por empresas particulares e do Governo, como a Embratur, criada em 1966, contribuiu para que o Brasil se tornasse um dos países da América do Sul mais visitados, gerando empregos e renda para o Estado. Mas é preciso ressaltar que as estratégias utilizadas na publicidade também passaram a atrair turistas, os quais movidos por representações construídas pelo estímulo que as imagens usadas nas campanhas despertavam, chegam por aqui na busca de prazeres mais específicos.

Como as campanhas associavam fotos de mulheres lindas às belas praias brasileiras e de mulheres seminuas à maior festa popular, que é o carnaval, o Brasil passou a ser visto como um país propício para se vivenciar "fantasias" de todos os tipos. Há um ditado popular no qual se diz que "uma imagem vale mais que mil palavras". O estímulo do imaginário, associado à exaltação da sensualidade e à beleza escultural da mulher brasileira, contribui para a ideia de que, no Brasil, tudo é possível. Com toda essa promoção, dá para acreditar que realmente "Não existe pecado ao Sul do Equador", como é apresentado por Chico Buarque de Holanda na letra de sua música, lançada em 1990.

Dines (2012) relata um trecho de notícia de O Globo sobre Zweig, com uma pitada de malícia:

Todos já tinham ido embora e Zweig queria dar uma volta pela cidade. Pelo hall do hotel passa uma morena jambo, bem brasileira. Stefan Zweig acompanha com um olhar discreto o andar gracioso e arremata: "O café também tem outras virtudes". (DINES, 2012: p.41). 
Zweig, mesmo tendo reparado a beleza das mulatas, não garantiu o sucesso de sua obra, ao explorar esse tesouro brasileiro. Sua obra tornou-se sucesso por sua genialidade em decifrar a alma do ser humano, de enxergar com os olhos da alma, de captar a essência das pessoas e das coisas, e pela habilidade com as palavras. Em referência à habilidade de Zweig como escritor, Alfonsina Storni (1892-1938) disse: "Dai-lhe a sombra de uma folha, ele verá o bosque" (apud DINES, 2012, p.15). O sucesso da versão de sua obra sobre o Brasil também se deve aos seus tradutores, que tão bem souberam levar o autor aos seus leitores na língua alvo.

Quando é abordado que a ostensiva crítica dirigida ao Brasil, país do futuro contribuiu para o aumento das vendas desta edição e de outras obras de Zweig, quebra-se o mito de que uma obra, para ter um sucesso garantido, precisa que os críticos teçam bons comentários e indiquem-na para os leitores.

Representações que perduram na cultura do País até os dias atuais, constituem um aspecto interessante na obra. Infelizmente, uma delas é sobre o pensar de homens de todas as classes sociais que acreditam ser superiores, com autoridade e posse no que diz respeito à sua parceira. Essa crença machista ainda está presente na cultura brasileira, responsável por índice elevado de assassinatos de mulheres, comprovado por levantamentos estatísticos.

Como aporte teórico deste estudo, a Teoria das Representações Sociais, de Serge Moscovici, foi fundamental para a compreensão da formação e da importância das representações nesse trânsito do tradutor com as culturas envolvidas no processo tradutório, e como um texto literário pode influenciar na formação de novas representações.

Por fim, ao compreender a tradução como um lugar de "múltiplas determinações", fazse necessário que seja muito bem pensada para que, como produto, possa atender aos objetivos estabelecidos pelo tradutor para alcançar o seu leitor na língua de chegada.

Quanto a ser uma tradução mais estrangeirizada ou domesticada, deverá ser uma decisão do tradutor com base nos princípios éticos que norteiam a ação profissional e em propósitos estabelecidos pelo tradutor. Por isso, a importância da definição de uma linha de tradução. Vermeer, citado à p.19 desta dissertação, afirma que as duas formas não infligem danos à cultura de partida.

Caso a tradução esteja destinada a fins específicos, sua estratégia tradutória deverá estar voltada ao sentido que é desejado levar ao leitor, pois cada palavra apresentará um teor de sentido que deverá promover associações de ideias e, consequentemente, reflexões por 
parte do leitor da língua meta. As reflexões deverão gerar mudanças significativas nos contextos sociais por meio do compartilhamento dessas ideias.

As considerações aqui destacadas não descartam o propósito de despertar o interesse de estudantes e pesquisadores para a continuidade de estudos, que tenham como parâmetro a Teoria das Representações Sociais para análise das representações envolvidas nos contextos do original e da tradução. No entendimento de que o autor, o tradutor e o leitor estão envoltos de representações sociais em seus contextos, e de que muitas delas norteiam suas ações e visão de mundo, questões ainda serão levantadas a respeito das influências dessas representações na estrutura textual, na leitura e na interpretação do produto final, o original ou a tradução.

Quanto ao produto de um processo tradutório, a tradução, não há como deixar de se considerar como uma obra de arte, pois é o resultado desses ir e vir no trânsito do tradutor entre culturas, com o propósito de que as distâncias existentes entre as línguas possam ser minimizadas, e as culturas envolvidas possam ampliar o horizonte do leitor da tradução. Ao mesmo tempo, contribui para formar uma nova visão de mundo e para mudanças pessoais e interpessoais grandiosas, que irão influenciar gerações futuras. Ao se referir à importância desse movimento, Laraia (2009, p. 68) afirma que "o modo de ver o mundo, as apreciações de ordem moral e valorativa, os diferentes comportamentos sociais e mesmo as posturas corporais são assim produtos de uma herança cultural, ou seja, o resultado da operação de uma determinada cultura". Assim, o tradutor pode, realmente, ser visto como um "ser criador", "um artista".

Portanto, o presente trabalho encontra-se finalizado com a perspectiva de que o estudo realizado possa contribuir para novas pesquisas relacionadas aos elementos destacados no tema que dá título a esta dissertação - TRADUÇÃO, REPRESENTAÇÕES SOCIAIS E IDEOLOLGIA: O TRADUTOR ENTRE CULTURAS DISTINTAS. 


\section{REFERÊNCIAS}

ABAURRE, M. B. M. et al. Cenas de aquisição da escrita: o sujeito e o trabalho com texto. São Paulo: Campinas, Associação de Letras do Brasil (ALB); Mercado de Letras, 1997.

AGRA, K. L. de O. A integração da língua e da cultura no processo de tradução. 2007. Disponível em: <http://www.bocc.ubi.pt/pag/agra-klondy-integracao-da-lingua.pdf>. Acesso em 20 jan. 2016.

ALMEIDA, J. L. Tá na Rua. São Paulo: Xamã, 2001.

ALVES, F.; MAGAlHÃES, C.; PAGANO, A. Traduzir com autonomia. São Paulo: Contexto, 2000.

ANADON, M.; MACHADO, P. B. Reflexões teórico-metodológicas sobre as representações sociais. Salvador: UNEB, 2001.

ARAPIRACA, M. de A. Prólogo de uma paidéia lobatiana fundada no fazer lúdico e especulativo: A chave do tamanho. Universidade Federal da Bahia - Faculdade de Educação, 1996.

ARROJO, R. Oficina de tradução: a teoria na prática. 5. ed. São Paulo: Ática, 2007.

ARRUDA, A. Teoria das representações sociais e ciências sociais: trânsito e atravessamentos. Sociedade e Estado, Brasília. V. 24, n. 3, p. 739-766, set./dez. 2009. Disponível em: < http://www.scielo.br/pdf/se/v24n3/06.pdf>. Acesso em 28 out. 2016.

ASCH, S. E. Psicologia Social. Tradução de Dante Moreira Leite; Miriam Moreira Leite. $4^{\text {a }}$ edição. São Paulo: Nacional, 1977.

AUBERT, F. H. Modalidades de tradução: teoria e resultados. Disponível em: <http://www.revistas.usp.br/tradterm/article/viewFile/49775/53879>. Acesso em 21 out. 2015.

AZEVEDO, L. de A.; CAMARGOS, M.; SACCHETTA, V. Lobato, furacão na Botucúndia. São Paulo: Editora SENAC, 2000.

BAKER, M. Routledge Encyclopedia of Translation Studies. New York- USA, 2005

BAKHTIN, M. A Estética da criação verbal. São Paulo: Martins Fontes, 1992.

BAKHTIN, M. Maxismo e Filosofia de Linguagem 14ª ed. São Paulo: Hucitec, 2010.

BALLIU, C. "Los traductores transparentes: historia de la traducción en Francia durante el período clásico". In. Revista Hyeronymus Complutensis, Madrid: Centro Virtual Cervantes, edição de 1995, n.1. Disponível em: <http://cvc.cervantes.es/lengua/hieronymus/pdf/01/01_009.pdf>. Acesso em 24 nov. 2016. 
BARROS, C. S. As transformações no perfil da família brasileira a partir do conflito de gerações - década de 1970 - uma aproximação entre a história da família e a demografia histórica. 2016.

Disponível

em:

<http://diamantina.cedeplar.ufmg.br/2016/anais/demografia/92-149-1-

RV_2016_10_09_00_25_16_798.pdf>.Acesso em 02 fev. 2017.

BASSNETT, S. Estudos de Tradução. Tradução de Sônia Terezinha Gehring et al. Porto Alegre: UFRGS, 2005.

BASSNETT, S.; TRIVEDI, H. Translations Studies. London: Routledge, 1991.

BATALHA, M. C.; PONTES JR., G. Tradução. Petrópolis, Rio de Janeiro: Vozes, 2007.

BATISTA, J. A. B. Reflexões sobre o conceito antropológico de cultura. Revista Saber Eletrônico. Ano 1. Vol. 1, p. 106, Nov / Jun 2010 ISSN 2176-5588. Disponível em: $<$ http://www.unifaj.edu.br/NetManager/documentos/reflexoes $\% 20$ sobre $\% 20 \mathrm{o} \% 20$ conceito $\% 2$ 0antropologico\%20de\%20cultura.pdf>. Acesso em 20 nov. 2016.

BENEDETTI, I.; SOBRAL, A. (Orgs). Conversas com tradutores: balanços e perspectivas da tradução. São Paulo: Parábola, 2003.

BENEDICT, R. Padrões de Cultura. Tradução: Alberto Candeias. Lisboa: Livros do Brasil, 2000.

BENJAMIN, W. A tarefa do tradutor. Belo Horizonte: Fale/UFMG, 2008.

BENVENISTE, E. Problemas de linguística geral I. 5.ed. Campinas: Pontes Editores, 2005.

BENVENISTE, E. Problemas de linguística geral II. 2. ed. Campinas: Pontes, 2006.

BERMAN, A. A tradução e a letra ou $\mathbf{O}$ albergue do longínquo. Tradutores Marie-Hélène Catherine Torres, Mauri Furlan, Andreia Guerini. Rio de Janeiro: 7Letras/PGET, 2007.

BERMAN, A. A tradução e seus discursos. Tradução de Marlova Aseff. Alea vol.11 no.2 Rio de Janeiro Dec. 2009. Disponível em: <http://www.scielo.br/scielo.php?script=sci_arttext\&pid=S1517-106X2009000200011 e http://dx.doi.org/10.1590/S1517-106X2009000200011>. Acesso em 16 out. 2015.

BHABHA, H. K. O local da cultura. Tradução de Myriam Ávila, Eliana Lourenço de Lima Reis, Gláucia Renate Gonçalves. Belo Horizonte: UFMG, 1998.

BIBLIOTECA DA PRESIDÊNCIA DA REPÚBLICA. Disponível em: $<$ http://www.biblioteca.presidencia.gov.br/ex-presidentes/getulio-vargas>. Acesso em 11 nov. 2015.

BIBLIOTECA VIRTUAL DA USP - disponível em: <http://www.direitoshumanos.usp.br/index.php/UNESCOOrganiza\%C3\%A7\%C3\%A3o-dasNa\%C3\%A7\%C3\%B5es-Unidas-para-a-Educa\%C3\%A7\%C3\%A3o-Ci\%C3\%AAncia-eCultura/o-que-e-unesco.html>. Acesso em 27 dez. 2015. 
BIGNAMI, R. A imagem do Brasil no turismo. $2^{\text {a }}$ Edição. São Paulo: Aleph, 2005.

BLUME, R. F.; PETERLE, P. Algumas Reflexões Introdutórias. In: (Orgs.). Tradução e Relações de Poder. Tubarão: Copiart. Florianópolis: PGET/UFSC, 2013.

BOSI, A. Dialética da Colonização. $4^{a}$ ed. São Paulo: Companhia das Letras, 1992.

BRANCO, L. C. (Orgs.) A tarefa do tradutor, de Walter Benjamin: quatro traduções para o Português. Belo Horizonte: Fale/UFMG, 2008.

BRITTO, P. H. O tradutor como mediador cultural, in Synergies Brésil. Brasil. N. 2, 2010, p. 135- 141. Disponível em: <http://gerflint.fr/Base/Bresil_special2/britto.pdf〉. Acesso em 10 abr. 2016.

CAMPOS, C. O pensamento e a prática de Monteiro Lobato como tradutor. IPOTESI Revista de Estudos Literários, Juiz de Fora, v. 13, n. 1, p. 67-79, 2009. Disponível em: <http://www.ufjf.br/revistaipotesi/files/2011/04/8-O-pensamento-e-a-pr\%C3\%A1tica-deMonteiro-Lobato-como-tradutor.pdf>. Acesso em 20 abr. 2016

CAMPOS, D. V. Max Weber, o conhecimento sociológico da história: uma interlocução com a filosofia hegeliana. Dissertação de Mestrado em Sociologia da Universidade Federal de Minas Gerais, sob orientação do professor Renarde Freire Nobre. Maio de 2006. Disponível em: $\quad<$ http://www.bibliotecadigital.ufmg.br/dspace/bitstream/handle/1843/JAGF6W8NMU/daniel_disserta_o.pdf?sequence=1>. Acesso em 12 out. 2016.

CANDIDO, A. A literatura e a formação do homem. In: Ciência e cultura. São Paulo: USP, 1972.

CANDIDO, A. O direito a literatura. O esquema de machado de Assis. In: Vários Escritos. São Paulo: Duas Cidades, 1995.

CARDOSO, H. F.; IANNI, O. Homem e sociedade: leituras básicas de sociologia geral. 12a edição. São Paulo: Nacional, 1980.

CARNEIRO, M. L. T. O Anti-semitismo na Era Vargas (1930 - 1945). São Paulo: Brasiliense, 1988.

CHAMON, E. M. Q. de O. Representação Social da pesquisa pelos doutorandos em ciências exatas. Estudos e Pesquisas em Psicologia, Rio de Janeiro, Ano 6, n. 2, jul. 2006. Disponível em <http://pepsic.bvsalud.org/pdf/epp/v6n2/v6n2a03.pdf>. Acesso em 10 ago. 2016.

AZEVEDO, R. Ridendo castigat mores. Veja.com 2009. Disponível em: http://veja.abril.com.br/blog/reinaldo/ridendo-castigat-mores/. Acesso em 15 fev. 2017.

CORREA, A. 'Futuro chegou' para o Brasil. Estadão Política. Disponível em: $<$ http://politica.estadao.com.br/noticias/geral,futuro-chegou-para-o-brasil-dizobama,694678>._Acesso em 22 jan. 2017. 
CORTI, A. P. Estado Novo (1937-1945): A ditadura de Getúlio Vargas. Disponível em: $<$ http://educacao.uol.com.br/disciplinas/historia-brasil/estado-novo-1937-1945-a-ditadura-degetulio-vargas.htm>. Acesso em 11 nov. 2015.

CUCHE, D. A Noção de Cultura nas Ciências Sociais. Bauru: EDUSC, 1999.

DERRIDA, J. Torres de Babel. Tradução de Junia Barreto. Belo Horizonte: UFMG, 2006, pp. 11-12.

DESLILE, J.; WOODSWORTH, J. Os Tradutores na História. Tradução de Sérgio Bath. São Paulo: Ática, 1998.

DINES, A. Morte no paraíso. A Tragédia de Stefan Zweig. Rio de Janeiro: Rocco, 2012.

DINES, A. No País do Futuro: a biografia de um livro. Petrópolis: EMC, 2009.

DUARTE, V. M. do N. "Monteiro Lobato e sua autenticidade pré-modernista "; Brasil Escola. Disponível em <http://brasilescola.uol.com.br/literatura/monteiro-lobato-suaautenticidade-premodernista.htm>. Acesso em 3 fev. 2017.

DURDUREANU, I. I. Translation of cultural terms: possible orimpossible? JoLIE 4/2011. Disponível em: <http://webcache.googleusercontent.com/search?q=cache:http://www.uab.ro/jolie/2011/4_dur dureanu_irina.pdf\&gws_rd=cr\&ei=QxYjWICBEoOwwAT956PYBw>. Acesso em 6 nov. 2016.

DURKHEIM, E. Educação e Sociologia. São Paulo: Melhoramentos, 1978.

DURKHEIM, E. As regras do método sociológico in OLIVEIRA, P. de S. (org), Metodologia das Ciências Humanas. São Paulo: Hucitec, 1998.

DURKHEIM, E. As regras do método sociológico. Tradução de Pietro Nassetti. São Paulo: Ed. Martin Claret, 2011.

ESTEVAM, J. G. O reconhecimento da alteridade como possibilidade de construção de um novo paradigma na cultura ocidental em Joel Birman e Emmanuel Lévinas. Horizonte: Revista de Estudos de Teologia e Ciências da Religião. 2009;6(12)169-179. Disponível em: $<$ http://periodicos.pucminas.br/index.php/horizonte/article/view/446>. Acesso em 20 mar. 2015.

FAGUNDES, J. S. Tenda dos milagres/Tent of miracles: A Tradução como um processo de mediação cultural. Monografia submetida ao Departamento de Letras Estrangeiras Modernas da Universidade Federal de Juiz de Fora. Ano: Set. 2001. Disponível em: <http://www.ufjf.br/bachareladotradingles/files/2011/02/Juliana-Fagundes.pdf $>$. Acesso em 8 nov. 2016.

FARR, R. M. As raízes da psicologia social moderna (1872-1954). Tradução de Pedrinho A. Guareschi; Paulo V. Maya. 5 ed. Petrópolis: Vozes, 2002. 
FAVERI, C. B. de; TORRES, M. H.C. T. E. (orgs.) Clássicos da teoria da tradução. Florianópolis: UFSC, Núcleo de Tradução, 2004.

FERNANDES, C. Era Vargas. Disponível em: 〈http://www.brasilescola.com/>. Acesso em 11 nov. 2015.

FERNANDES, M. L.S. Entre o estrangeiro e o leitor: Quintana e a tradução. Ano 2012.

Disponível em:

<http://www.repositorios.ufpe.br/revistas/index.php/INV/article/view/1536/1200>. Acesso em 15 out. 2015.

FERRARI, M. Augusto Comte, o homem que quis dar ordem ao mundo. Disponível em: $<$ http://revistaescola.abril.com.br/historia/pratica-pedagogica/auguste-comte-

423321.shtml?page=3\#. Acesso em 17 jul. 2016.

FURLAN, M. Brevíssima história da teoria da tradução no Ocidente: I Os Romanos in Cadernos de Tradução $\mathrm{n}^{0}$ VIII. Florianópolis: PGET, 2003. (p.11-28. Disponível em: $<$ https://periodicos.ufsc.br/index.php/traducao/article/viewFile/5881/5561 . Acesso em 12 jan. 2016.

FOUCAULT, M. As palavras e as coisas. Uma arqueologia das ciências humanas. Tradução de Salma Tannus Muchail. São Paulo: Martins Fontes, 2002.

GARCIA, N. J. Apresentação do livro Brasil, país do futuro, de ZWEIG, S. Edição eletrônica: Ed Ridendo Castigat Mores, 2001. Disponível em: <http://www.ebooksbrasil.org/eLibris/paisdofuturo.html>._Acesso em 27 dez. 2016.

GENTZLER, E. Teorias contemporâneas da tradução. Tradução de Marcos Malvezzi. São Paulo: Madras, 2009.

GUARESCHI, P. A.; JOVCHELOVITCH, S. (Orgs.). Textos em representações sociais.14. ed. Petrópolis, RJ: Vozes, 2013.

INDRUSIAK, E. B. O papel dos estudos de tradução na busca pela identidade cultural latinoamericana. Revista de Letras. São Paulo, 45 (2): 121-134, 2005. Disponível em: <http://seer.fclar.unesp.br/letras/article/view/76>._Acesso em 13 jun. 2016.

JODELET, D. (org.). As representações sociais. Rio de Janeiro: EdUERJ, 2001.

JODELET, D. Représentations sociale: phénomènes, concept et théorie. In: MOSCOVICI, S. Psychologie sociale. Paris: PUF, 1984.

JODELET, D. Représentations sociales: um domaine em expansion. In JODELET(ED.) Les représentations sociales. Paris: PUF,1989.

JOVCHELOVITCH, S. Representações sociais e esfera pública: a construção simbólica dos espaços públicos no Brasil. Petrópolis, RJ: Vozes, 2000.

LARAIA, R. de B. Cultura: um Conceito Antropológico. Rio de Janeiro: Zahar, 2009. 
LEFÈBVRE, H. Metafilosofia - Prolongamentos. Tradução e Introdução: Roland Corbisier. ed. 2. Rio de Janeiro: Civilização Brasileira, 1979.

LÉPINETTE, B. La historia de la traducción. Metodologia. Apuntes bibliográficos HISTAL, enero 2004. Disponível em:< http://www.histal.ca/wp-content/uploads/2011/08/Lahistoria-de-la-traduccion-metodologia-apuntes-bibliograficos.pdf >. Acesso em 23 out. 2015.

LIMA, E. SISCAR, M. O decálogo da Desconstrução: Tradução e Desconstrução na obra de Jacques Derrida. Alfa, São Paulo, 44(n.esp.): 99-112, 2000. Disponível em: <http://seer.fclar.unesp.br/alfa/article/viewFile/4282/3871>. Acesso em 8 nov. 2016.

LISBOA, K. M. Entre o passado europeu e o futuro americano: dois ensaios sobre o Brasil da década de 1930. História. Ciência. Saúde - Manguinhos vol.21 nº.1 Rio de Janeiro jan./mar. 2014 Epub 14-Fev-2014.Disponível em: <http://www.scielo.br/scielo.php?script=sci_arttext\&pid=S010459702014000100317\&lng=pt \&nrm=iso\&tlng=en\#fn1>. Acesso em 22 dez. 2016.

LOBATO, J. B. M. Mundo da lua e miscelânea. 11ª ed. São Paulo: Brasiliense, 1964.

MARKOVÁ, I. Dialogicidade e Representações Sociais: as dinâmicas da mente. Petrópolis: Vozes, 2006.

MARTINS, J. de S. O senso comum e a vida cotidiana. Tempo Social; Revista Sociologia USP, S. Paulo: 10(1): 1-8, maio de 1998.

MARX, K. Contribuição para a crítica da economia política. Tradução Maria Helena Barreira Alves. Lisboa: Estampa, 1977; São Paulo: Mandacaru, 1989, p. 28-29.

MENDES, D. R. Monteiro Lobato, O Tradutor. Monografia submetida ao Departamento de Letras Estrangeiras Modernas da Universidade Federal de Juiz de Fora para a obtenção do grau de bacharel em Letras. Março de 2012.

MESCHOMMIC, H. Critique du rythme. Paris: Verdier Poche, 1999.

MICELI, S. Intelectuais à brasileira. São Paulo: Companhia das Letras, 2001.

MILTON, J. Tradução: teoria e prática. São Paulo: Martins Fontes, 1998.

MILTON, J. Tradução: Teoria e Prática. São Paulo: Martins Fontes, 2010.

MINAYO, M. C. de S. O conceito de Representações Sociais dentro da sociologia clássica. In: GUARESCHI, P.; JOVCHELOVITCH, S. (orgs.) Textos em Representações Sociais. Petrópolis: Vozes, 1995, p. 89-111.

MOREIRA, J. O.; VASQUEZ, U. A concepção de subjetividade em Lévinas: da solidão da hipóstase ao encontro com a alteridade. Belo Horizonte, 2007 (Texto não publicado).

MOSCOVICI, S. A máquina de fazer deuses. Rio de Janeiro: Imago, 1990. 
MOSCOVICI, S. A Representação Social da Psicanálise. Tradução de Álvaro Cabral. Rio de Janeiro: Zahar Editores, 1978.

MOSCOVICI, S. Representações Sociais - Investigações em psicologia social. Tradução de Pedrinho A. Guareschi. Petrópolis: Vozes, 2003.

MOSCOVICI, S. The phenomenon of social representations. In FARR, M.; MOSCOVICI, S. (eds.) Social Representations. Cambridge: Cambridge University Press, 1984.

MOTA, C. G. Cultura e política do Estado Novo (1937-1945). Encontros com a Civilização Brasileira. Rio de Janeiro: Civilização Brasileira, v. 7, jan. 1979.

NOGUEIRA, M. D. "O enigma de Stefan Sweig”. Revista ISTOÉ, Edição no 2433. Disponível em: <http://istoe.com.br/193964_O+ENIGMA+DE+STEFAN+ZWEIG/>. Acesso em 27 jul. 2016.

OLHER, R. M. Texto original e tradução - tal pai, tal filha? Disponível em:

<http://www.unicamp.br/iel/site/alunos/publicacoes/textos/t00007.htm>. Acesso em: 20 dez. 2016.

OLIVEIRA, L. L. Apresentação e Introdução. In: OLIVEIRA, L. L., VELlOSO, M. P., GOMES, A. C. Estado Novo, ideologia e poder. Rio de Janeiro: Zahar, 1982, p. 7-30.

OUSTINOFF, M. Tradução: história, teorias e métodos. Tradução: Marcos Marcionillo. São Paulo: Parábola Editorial, 2011.

PASCHOAL, S. Pressupostos para a formação e a atuação do tradutor (2007). Fragmentos, número 33, p. 215/228 Florianópolis/ jul - dez/ 2007. Disponível em: $<$ https://periodicos.ufsc.br/index.php/fragmentos/article/download/8665/8006>. Acesso em 20 jan. 2017.

PAES, J. P. Por Uma Literatura Brasileira de Entretenimento, em Aventura Literária. São Paulo: Companhia das Letras, 1990.

PAZ, O. Traducción: literatura y literalidade. Barcelona: Tusquets, 1981.

PEREIRA, C. H. da C. Sobre os diferentes métodos da tradução: a tradução no contexto político-pedagógico da bildung. Curitiba: junho, 2008. Disponível em: <http://www.humanas.ufpr.br/portal/letrasgraduacao/files/2014/08/Caio_Heleno.pdf>._Acesso em 17 jul. 2016.

PRADO, A. A. Intelectuais e educação no Estado Novo (1937/1945): o debate sobre a formação do professor primário rural. Revista Teias. 2007. Disponível em: <http://www.periodicos.proped.pro.br/index.php/revistateias/article/view/17>. Acesso em 16 out. 2015.

PRADO, C. L. A. A tradução na era Vargas de 1930 a 1940: o Tarzan brasileiro de Manuel Bandeira, Monteiro Lobato e Godofredo Rangel. Tese de Doutorado em Estudos Linguísticos e Literários em Inglês. Faculdade de Filosofia, Letras e Ciências Humanas da Universidade de São Paulo. Ano 2015. 
PYM, A. Teorías contemporáneas de la traducción. Materiales para un curso universitario. Tarragona: Intercultural Studies Group, 2012.

REIS, D. da S. Impactos da tradução escrita no Brasil do século XIX. Tradução em Revista 18, 2015/1, p. 36.

RIBEIRO, P. S. Durkheim e o Fato Social. Brasil Escola. Disponível em $<$ http://brasilescola.uol.com.br/sociologia/durkheim-fato-social.htm>. Acesso em 2 jul. 2016.

RICOUER, P. Sobre a tradução. Tradução e prefácio de Patrícia Lavelle. Belo Horizonte: Editora UFMG, 2012.

ROCHA, R. (ORGS.) Monteiro Lobato. Literatura Comentada. São Paulo: Abril Educação. 1981 ,

RODRIGUES, C. C. Ecos de Babel. Estudos Linguísticos XXXV, p. 60-65, 2006. Disponível em: $\quad<$ http://www.gel.org.br/estudoslinguisticos/edicoesanteriores/4publica /sistema06/ccr.pdf >. Acesso em 20 out. 2015.

RODRIGUES, C. C. Tradução: A questão da equivalência. Alfa, São Paulo, 44 (n.esp.): 8998, 2000. Disponível em: <http://seer.fclar.unesp.br/alfa/article/viewFile/4281/3870>. Acesso em15 ago. 2016.

RODRIGUES, L. De O. Introdução à teoria de Max Weber. Brasil Escola. Disponível em: $<$ http://brasilescola.uol.com.br/sociologia/introducao-teoria-max-weber.htm>. Acesso em 17 jul. 2016.

RÓNAI, P. A Tradução vivida. $1^{\text {a }}$ ed. Rio de Janeiro: Educom, 1976.

SÁ, C. P. de. Representações Sociais: o conceito e o estado atual da teoria. In: SPINK, M. J. (org.). O conhecimento no cotidiano. São Paulo: Brasiliense, 1995.

SAPIR, E. A Linguagem, introdução ao estudo da fala. Tradução de Joaquim Mattoso Câmara Jr. Rio de Janeiro: INL, 1921.

SAUSSURE, F. de. Curso de linguística geral. 27 ed. São Paulo: Cultrix, 2006.

SEIXAS, J. A. Brasil, país do futuro: políticas do esquecimento e imagens identitárias de denegação. Revista de Ciências Sociais e Humanas. V. 25, n. 64, 2015. Disponível em: https://www.metodista.br/revistas/revistas-unimep/index.php/impulso/article/view/2835/1683 Acesso em 15 jan.2017.

SILVA, E. L. da; MENEZES, E. M. Metodologia da pesquisa e elaboração de dissertação. 4. ed. rev. atual. - Florianópolis: UFSC, 2005.

SILVA, J. O. A transformação Social na visão da sociologia clássica. Disponível em:<http://www.unioeste.br/campi/cascavel/ccsa/IIISeminario/paineis/Painel\%2005.pdf>. Acesso em 23 out. 2015. 
SILVA, N. de M. A. Representações Sociais, Ações e Sociedade Pensante: Interações e Perspectivas Possíveis em Educação Social Atos de Pesquisa em Educação - PPGE/ME FURB ISSN 1809- 0354 v. 5, nº 1, p. 2-20, jan./abr. 2010. Revista do Programa de PósGraduação em Educação - FURB Universidade Regional Blumenau. Disponível em <http://proxy.furb.br/ojs/index.php/atosdepesquisa/article/view/1958/1311>. Acesso em 21 set. 2016.

SILVEIRA, E. (et al.) Encontros com a Civilização Brasileira. Rio de Janeiro: Civilização Brasileira, 1979.

SNELL-HORNBY, M. A "estrangeirização" de Venuti: o legado de Friedrich Schleiermacher aos Estudos da tradução? Pandaemonium. São Paulo, v. 15, n. 19, Julho/2012, p. 185-212. Disponível em: <http://www.revistas.usp.br/pg/article/view/39802/42666>. Acesso em 23 jan. 2016.

SOUSA, R. Era Vargas - Estado Novo (1937 - 1945). Disponível em: $<$ http://www.mundoeducacao.com/historiadobrasil/era-vargas-estado-novo.htm>. Acesso em 11 nov. 2015.

SOUSA FILHO, A. Cultura, ideologia e representações. In: CARVALHO, M. do R. de; PASSEGGI, M. da C.; SOBRINHO, M. D. (Org.). Representações sociais: teoria e pesquisa. 1 ed. Mossoró: Fundação Guimarães Duque/Fundação Vingt-un Rosado, 2003, v. 1376, p. 71 82. ISBN 85-89888-01-0)

SPINK, M. J.; MEDRADO, B. Produção de Sentidos no cotidiano: uma abordagem teóricometodológica para análise das práticas discursivas in: SPINK, M. J. (org.): Práticas Discursivas e Produção de Sentidos no Cotidiano. São Paulo: Cortez, 2004.

STOOSS-HERBERTZ A. Os Leitores e as leituras da obra de Stefan Zweig no Brasil. Fênix Revista de História e Estudos Culturais. Volume 4. Ano IV número 2. ISSN 1807-6971 Abril/Maio/Junho de 2007. Disponível em: <http://www.revistafenix.pro.br/PDF11/Dossie.artigo.2_Adelaide.Stooss-Herbertz.pdf>. Acesso em 27 dez. 2015.

STRASSER, M. P. Sobre as ruinas de Babel - A construção da Tradução em Borges. Scientia Traductionis, n.13, 2013. Disponível em: <https://periodicos.ufsc.br/index.php/scientia/article/view/30239/25161>. Acesso em 16 nov. 2016.

SUPERTI, E. O positivismo de Augusto Comte e seu projeto político. Dissertação de mestrado, O Positivismo e a Revolução de 30: A Construção do Estado Moderno no Brasil. Programa de Pós Graduação em Ciências Sociais da Universidade Federal de São Carlos em setembro de $1998 . \quad$ Disponível em: <http://www.faeso.edu.br/horus/artigos\%20anteriores/2003/superti.htm>. Acesso em 11 out. 2016.

THOMAZ, J. A sociologia e as teorias sociológicas. Disponível em: $<$ http://www.artigos.com/artigos-academicos/5403-a-sociologia-e-as-teorias sociologicas\#user-profile>._Acesso em 17 jul. 2016. 
TODOROV, T. The Conquest of America: The Question of the Other. Translated from the French by Richard Howard. New York: Harper \& Row, 1984.

VASCONCELLOS, Z. O Universo Ideológico da Obra Infantil de Monteiro Lobato. In: Cadernos da Puc - RJ: Sobre Monteiro Lobato, R.J., Série Letras - 10/82, p31.-69, out.1982.

VELloso, M. P. Os intelectuais e a política cultural do Estado Novo. Rio de Janeiro: Centro de Pesquisa e Documentação de História Contemporânea do Brasil, 1987. Disponível em:

<http://bibliotecadigital.fgv.br/dspace/bitstream/handle/10438/6604/803.pdf?sequence=1>.

Acesso em 11 nov. 2015.

VERMEER, H. J. Hermeneutik und Übersetzung(swissenschaft). In: TEXTconTEXT 9 (1994), Nr. 3, 163-182.

VÍDEO - Alberto Dines fala sobre Stefan Zweig - YouTube, de 19/abr./2013, Editora Zahar.

WHARTON, C. The Hammer and Sickle: The Role of Symbolism and Rituals in the Russian. Disponível

em:

$<$ http://www.westminstercollege.edu/myriad/index.cfm?parent $=2514 \&$ detail $=4475 \&$ content $=$ 4797>. Acesso em 29 mar. 2016.

WOLTON, D. Pensar a comunicação. Tradução de Vanda Anastácio. Portugal: Difusão Editorial, 1999.

WYLER, L. Línguas, poetas e bacharéis: Uma crônica da tradução no Brasil. Rio de Janeiro: Rocco, 2003.

WYLER, L. A tradução é uma ponte entre duas culturas. Entrevista concedida à jornalista Gisela Anauate. Revista Época. Ed. 493. Novembro/2007. Disponível em: <http://revistaepoca.globo.com/Revista/Epoca/0,,EDG79809-5856,00.html>._Acesso em 16 set. 2016.

ZWEIG, S. Brasil país do futuro. Tradução de Odilon Gallotti. Rio de Janeiro: Editora Guanabara, 1941.

ZWEIG, S. Brasil, País do Futuro. Tradução de Odilon Gallotti. Versão eletrônica para eBook. Edição Ridendo Castigat Mores, 2001. Disponível em: http://www.ebooksbrasil.org/adobeebook/paisdofuturo.pdf Acesso em 20 fev. 2017.

ZWEIG, S. Brazil land of the future. Translated by Andrew St. James. Great Britain: Cassell and Company Ltd., 1942. 